University of Rhode Island

DigitalCommons@URI

1991

\title{
ASSESSMENT OF ORGANIZATIONAL AND FINANCIAL NEEDS ASSOCIATED WITH STORMWATER MANAGEMENT FOR WATER QUALITY IN THE GREENWICH BAY WATERSHED IN WARWICK, RHODE ISLAND
}

Laura J. Prickett

University of Rhode Island

Follow this and additional works at: https://digitalcommons.uri.edu/theses

\section{Recommended Citation}

Prickett, Laura J., "ASSESSMENT OF ORGANIZATIONAL AND FINANCIAL NEEDS ASSOCIATED WITH STORMWATER MANAGEMENT FOR WATER QUALITY IN THE GREENWICH BAY WATERSHED IN WARWICK, RHODE ISLAND" (1991). Open Access Master's Theses. Paper 417. https://digitalcommons.uri.edu/theses/417

This Thesis is brought to you for free and open access by DigitalCommons@URI. It has been accepted for inclusion in Open Access Master's Theses by an authorized administrator of DigitalCommons@URI. For more information, please contact digitalcommons-group@uri.edu. 


\begin{abstract}
Assessment of Organizational and Financial NeEdS Associated with Stormwater Management FOR WATER QUALITY IN THE GREeNWICH BAY WATERShED IN WARWICK, RHODE ISLAND
\end{abstract}

\author{
BY \\ LAURA J. PRICKETT \\ A Research Project Submitted In \\ Partial Fulfillment Of The Requirements \\ for the Degree of \\ Master Of Community Planning
}

UNIVERSITY OF RHODE ISLAND

1995 


\section{MASTER OF COMMUNITY PLANNING \\ RESEARCH PROJECT \\ OF}

LAURA J. PRICKETT

Approved:

Major Professor

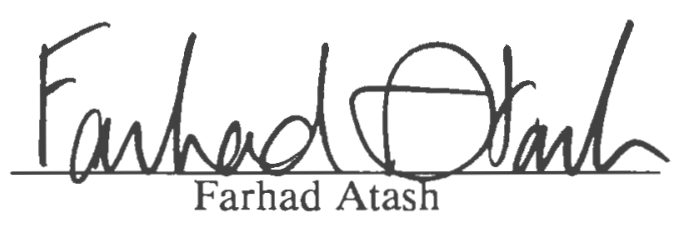

Acknowledged:

Director

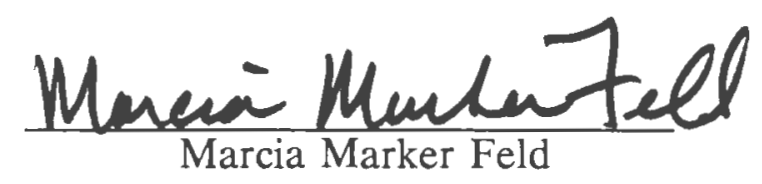




\begin{abstract}
Over the past several years there has been a growing awareness of water pollution problems in Greenwich Bay, a subembayment of Narragansett Bay which contains valuable shellfish beds. Studies have shown that water quality problems in the bay are due largely to nonpoint source pollution, which is conveyed by stormwater runoff. Nonpoint source pollution can be treated with a variety of source-control and structural techniques to manage stormwater, known as best management practices, or BMP's. Establishing stormwater BMP's to address water quality is often complicated by the fact that stormwater management has historically been a low priority for most communities, and by the high cost of some BMP's.

This study analyzes the existing stormwater management policies and activities in Warwick, identifies changes that may be made to address water quality issues in the Greenwich Bay watershed, and assesses potential organizational and financial needs that would result from those changes. The analysis was conducted using a rational approach to program analysis, outlined by Morgan (1984). Major stormwater quality problems are defined, along with a statement of goals and objectives for improving water quality. Current stormwater management activities are identified. Possible changes in the stormwater management program and their expected levels of effectiveness are described. An assessment is made of impacts that changes may have on the existing program, and suggestions are made for prioritizing activities. The study concludes with a review of potential funding sources for BMP's and organizational structures that have been used for stormwater management programs.
\end{abstract}




\section{ACKNOWLEDGEMENTS}

This project has benefitted considerably from the ideas, information, advice, critiques, and goodwill provided by many individuals. I would especially like to acknowledge the help of Farhad Atash, my major professor, for always being available to advise me regarding difficult aspects of the study. My other committee members -- William Villella, of the Warwick Department of Public Works, and David Westcott, of the Maguire Group -- were also generous with their time in reviewing my work and discussing it with me.

This project would not have been possible without the interest and support of Charles T. Sheahan, Director of the Warwick Department of Public Works, and Jonathan Stevens, Director of the Warwick Planning Department. They assisted in developing the problem statement and provided me with access to staff members and information in their departments.

I am grateful to the following individuals for reviewing early drafts of various chapters and providing technical assistance in their areas of expertise: James Boyd of the Rhode Island Coastal Resources Management Council, Susan Adamowicz of the Narragansett Bay Project, William DePasquale of the Warwick Planning Department, Lorraine Joubert of the University of Rhode Island Cooperative Extension, and Eric Offenberg of the Southern Rhode Island Conservation District.

Although they did not advise me on this specific project, this work reflects help and advice I have received from several faculty members of the University of Rhode Island Graduate Curriculum in Community Planning and Area Development. In particular, past courses and conversations with Marcia Marker Feld, Marshall Feldman, and Marjorie Jensen helped me formulate the research design and think critically.

Finally, I would like to thank my fiance, Roger Hallsten, for his support and limitless patience throughout the duration of this project. I would also like to thank my parents, Gordon and Jean Prickett, for their interest and encouragement in my work. 


\section{TABLE OF CONTENTS}

Chapter 1: Introduction . . . . . . . . . . . . . . . . . 1

Background and Problem Statement . . . . . . . . . . . . . . 1

Objectives of the Study . . . . . . . . . . . . . . . . . . . . 9

Approach and Method of the Study . . . . . . . . . . . . . . . 9

Chapter 2: Defining the Stormwater Quality Problem . . . . . . . . . . . . . . 14

Water Quality Problems in Greenwich Bay . . . . . . . . . . . . . . . . . . . 14

Nonpoint Source Pollution and Stormwater . . . . . . . . . . . . . . 18

Pollution and Stormwater Management . . . . . . . . . . . . . . . . . . . . . 22

Stormwater Management Regulations . . . . . . . . . . . . . . . . . . . . 23

Stormwater Quality, Existing Resources and Goals . . . . . . . . . . . . . . . 27

Community Perceptions of the Stormwater Problem . . . . . . . . . . . . . . . . 28

Statement of Stormwater Quality Problems . . . . . . . . . . . . . . . . 30

Stormwater Quality Goals and Objectives . . . . . . . . . . . . . . . . . . . 32

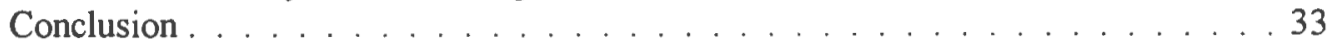

Chapter 3: Description of Current Stormwater

Management Program . . . . . . . . . . . . . . . . . . . . . . . . . 34

Statement of Authority to Manage Stormwater . . . . . . . . . . . . . . . . 34

Purpose of Stormwater Management in Warwick . . . . . . . . . . . . 36

Stormwater Management Policies . . . . . . . . . . . . . . . . . . . . . . . 39

Description of Stormwater Management Activities . . . . . . . . . . . . . . . . 40

Allocation of Resources for Stormwater Management . . . . . . . . . . . . . . . 49

Conclusion . . . . . . . . . . . . . . . . . . . . . . . . . 56

Chapter 4: Report on Stormwater Management Practices

for Water Quality Improvement . . . . . . . . . . . . . . . . . . . . . 57

Procedures for Selecting BMP's . . . . . . . . . . . . . . . . . . . . 58

Approach for Identifying Appropriate BMP's . . . . . . . . . . . . . . . 61

Stormwater Planning Activities . . . . . . . . . . . . . . . . . . . . . 64 64

Pre-development and Construction Activities . . . . . . . . . . . . . . . 70

Resource Maintenance and $/$ or Restoration . . . . . . . . . . . . . . . . 77

Structural Best Management Practices . . . . . . . . . . . . . . . . . . . . 87

Conclusion . . . . . . . . . . . . . . . . . . . . . . . 100

\section{Chapter 5: Assessment of Potential Organizational}

and Financial Needs . . . . . . . . . . . . . . . . . . . . . . . . . . 101

Selection of Alternatives . . . . . . . . . . . . . . . . . . . . 102

Stormwater Planning Activities . . . . . . . . . . . . . . . . . . . . 103

Pre-development and Construction Activities . . . . . . . . . . . . . . 106

Resource Maintenance and/ or Restoration . . . . . . . . . . . . . . . . . . . 111

Structural Best Management Practices . . . . . . . . . . . . . . . . . . . . . . 122

Potential Organizational Needs . . . . . . . . . . . . . . . . . . . . . 125

Estimates of Potential Financial Needs . . . . . . . . . . . . . . . . . 125 
Chapter 6: Summary of Constraints and Opportunities f . . . . . . . . . . . . . 128

Suggestions for Prioritizing Alternatives . . . . . . . . . . . . . . . . 128

Overview of Potential Funding Sources . . . . . . . . . . . . . . . . . . . 134

Review of Organizational Structures . . . . . . . . . . . . . . . . . . . . . 143

Conclusion . . . . . . . . . . . . . . . . . . . . . . . . . 147

Appendices . . . . . . . . . . . . . . . . . . . . . 150

1: Land Uses in the Study Area . . . . . . . . . . . . . . . . 150

2: Developed Land in the Study Area . . . . . . . . . . . . . . . . 152

3: Undeveloped Land in the Study Area . . . . . . . . . . . . . . . . . 153

4: Stormwater Holding Structures in Warwick . . . . . . . . . . . . . 154

5: Stormwater Holding Structures in Study Area . . . . . . . . . . . . . 157

6: Maintenance Checklist . . . . . . . . . . . . . . . . . . 159

7: Schedule of Building Permit Fees . . . . . . . . . . . . . . . . . . 160

8: Private Grant-Making Organizations . . . . . . . . . . . . . . . 161

9: Federal Grants . . . . . . . . . . . . . . . . . . . . . . . 162

Bibliography . . . . . . . . . . . . . . . . . . . . . . . 164 


\section{LIST OF TABLES}

2.1. Greenwich Bay Use Classification and Attainment . . . . . . . . . 16

3.1. Criteria for Prioritizing Stormwater Capital Improvements . . . . . . . 37

3.2. Comparison of Actions that May Require Stormwater Management Review . . . . . . . . . . . . . . . . . . . 45

3.3. Estimates of Operational Budgets for Stormwater Management (SWM), FY 1994-95 . . . . . . . . . . . . . . . . . . . . . 54

3.4. Capital Improvement Program and Budget Funds for Stormwater Management Projects . . . . . . . . . . . . . . . . 55

4.1. Estimated Construction Costs for ED Dry Ponds _ . . . . . . . . .993

4.2. Estimated Costs for Conveyance and Pre-treatment BMP's . . . . . . . 99

5.1. Comparison of Stormwater Management Planning Activities . . . . . . 103

5.2. Comparison of Pre-Development and Construction Activities . . . . . 107

5.3. Comparison of Maintenance and Restoration Activities _. . . . . . 112

5.4. Potential Cost of Additional Maintenance Activities in the

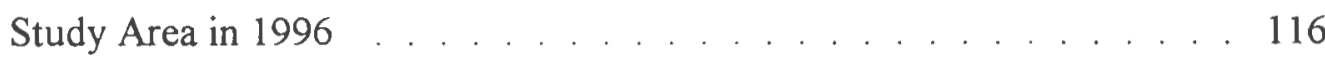

5.5. Approximation of Amount of Highly-Developed Land in Study Area . . 117

5.6. Estimated Impervious Area for Highly-Developed Land in Study Area . . 118

5.7. Comparison of Structural BMP's . . . . . . . . . . . . . . 123

5.8. Potential Organizational Needs Resultant from Establishing Stormwater Quality Goals . . . . . . . . . . . . . . . . 126

5.9. Potential Financial Needs Resultant from Establishing Stormwater Quality Goals

A.1. Approximation of Land-Use Distribution in Study Area . . . . . . 150 
A.2. Approximation of Amount of DevelopedLand in Study Area . . . . . . 152

A.3. Approximation of Amount of Undeveloped Land in Study Area . . . . . 153

A.4. Master Data Base of Stormwater Holding Structures, City of Warwick, April 1, 1995 . . . . . . . . . . . . . . . . . . . . 155

A.5. Stormwater Holding Structures in Study Area . . . . . . . . . . . . . . 157

A.6. Maintenance Activities and Frequency of Performance in Warwick . . . . 159

A.7. Private Grant-Making Organizations with Environmental Interests . . . . 161

A.8. Federal Grants for which Greenwich Bay Initiatives May Be Eligible . . . . . . . . . . . . . . . . . . . . . . . 162

\section{LIST OF FIGURES}

1.1. Greenwich Bay Watershed . . . . . . . . . . . . . . . 4

6.1. Subbasins in Greenwich Bay Watershed . . . . . . . . . . . . . . . . . 133 


\section{Chapter One}

Introduction

\section{Background and Problem Statement}

Greenwich Bay is a shallow embayment of Narragansett Bay with a surface area of 4.3 square miles. It contains the most productive shellfishing beds in Rhode Island (Ganz et al, 1993), numerous marinas that support recreational boating activities, and several bathing beaches. Shellfishing in Greenwich Bay and related industries have traditionally been an essential component to the economy of the City of Warwick, which surrounds the bay. The value of these industries has been estimated at \$4 million per year (NBP, 1994).

Pollution associated with urbanization in Greenwich Bay's watershed, however, poses a threat to the health of this resource. In December, 1992, Greenwich Bay was closed to shellfishing due to levels of fecal coliform bacteria which exceeded shellfish growing water certification standards (RIDEM, 1988b). In 1994 a beach along the bay was also closed to swimming for a short period of time due to elevated fecal coliform counts. Since July, 1994, the bay has been open to shellfishing during dryweather conditions. State and local officials, environmental and marine-trade organizations, as well as members of the general public, however, have expressed concern over the future health of Greenwich Bay. Studies of pollutant loadings indicate that there are many diffuse (nonpoint) sources of pollution in the bay's watershed that are flushed into the bay during wet-weather conditions (RIDEM, 1992; FDA, 1994; City of Warwick, 1994b). 
Greenwich Bay has a relatively small watershed of approximately 26 square miles. Approximately 23 square miles $(88 \%)$ of its watershed lie within the City of Warwick, Rhode Island; the remaining watershed area is located in the towns of East Greenwich and West Warwick, Rhode Island ${ }^{1}$. The watershed is depicted in Figure 1.1.

Nonpoint Source Pollution

The initial focus of water pollution control measures in the United States was on "point sources" of pollution. The United States Environmental Protection Agency (US EPA) has defined point sources of pollution as "any discernible, confined and discrete conveyance, ..., from which pollutants are or may be discharged" (US EPA, 1993a). Typical point sources that have been regulated by the federal government have been sanitary sewer and industrial outfalls. However, as impacts from point sources have been mitigated, the environmental impacts of other, diffuse sources carried by storm runoff has become more apparent. Water pollution that is not issued from point sources is termed "nonpoint source pollution" (US EPA, 1993a).

Nonpoint source pollution is caused by rainfall or snowmelt moving over or through the ground, carrying natural and anthropogenic pollutants into lakes, rivers, streams, wetlands, estuaries, other coastal waters and groundwater (US EPA, 1993a). The sources of the pollution found in runoff following rain events and snowmelt are

\footnotetext{
1 A portion of the town of North Kingstown would also be included if the Hunt River were considered part of the Greenwich Bay watershed. This study has not included the Hunt River, since its effect on water quality problems in Greenwich Bay has not been documented.
} 
many. They include: atmospheric deposition, individual on-site septic systems, wildlife and pet wastes, underground storage tanks, gas stations and automotive service stations, pesticide and fertilizer use, deposits on impervious surfaces, construction projects, and wastes from marina and boating activities (Horsley and Witten, 1994).

Water bodies contaminated by nonpoint sources of pollution require varied mitigation strategies that address a wide range of problems (US EPA, 1993a; NOAA and US EPA, 1993a). Strategies range from various types of source reduction to various stormwater treatment practices and include regulatory and non-regulatory approaches. Strategies should be developed to treat the specific problems associated with the land uses within a particular water body's watershed (Horsley and Witten, 1994). Although Greenwich Bay's watershed is occupied by four municipalities, Warwick occupies the majority of this area, is more urbanized than the other communities, and has shown the greatest interest in protecting the bay. For these reasons, as well as to limit the complexity of analysis, this study will focus on that part of the Greenwich Bay watershed that lies within Warwick. A highly developed city in the Providence metropolitan area, with a population of 85,427 in 1990 (Bureau of Census, 1993), Warwick covers a total of 35 square miles. The predominant land use in the study area is residential ${ }^{2}$, although stormwater collected from T.F. Green State Airport, large commercial developments, and major highways also drains into the bay.

\footnotetext{
${ }^{2}$ See Appendix 1: Land Uses in Study Area.
} 
Figure 1.1

Greenwich Bay Watershed

\section{Legend}

Greenwich Bay watershed boundary

Municipal boundaries

Prepared by:

Laura Prickett

April 29, 1995

Sources:

U.S. Geologic Survey E. Greenwich \& Crompton Quadrangles, 1975; M. Brusseau,

Warwick Planning Dept., 1993. 
cleaning up Greenwich Bay and has made progress in numerous initiatives (City of Warwick, 1994f).

In June 1994 residents of Warwick approved a bond referendum which allocated $\$ 5$ million for projects designed to benefit the bay. These funds were allocated as follows: $\$ 2.5$ million for sewer construction in the watershed, $\$ 1$ million for a grant/loan program for homeowners to repair or replace failing septic systems, and $\$ 1.5$ million for research, design and construction of stormwater structures (structural best management practices or BMP's) that would remove pollutants instead of flushing untreated drainage directly into the bay and its tributaries.

The funding for stormwater activities will enable the city to sponsor research of stormwater impacts in portions of the Greenwich Bay watershed (scheduled to begin in Summer 1995, augmenting current studies sponsored by RIDEM) and implement certain mitigation pilot projects. However, it will not enable the city to fully develop a comprehensive stormwater management program, a recommendation made in the Greenwich Bay Plan. The city's 1991 Comprehensive Plan also calls for the development of a "master plan for drainage system improvements". Although there are few published definitions of the term, a "stormwater master plan" generally identifies a system of improvements and regulations, which maximizes the effectiveness of each individual component (ASCE and WEF, 1992; Engemoen and Krempel, 1985). The Greenwich Bay Plan's stormwater management recommendations include installing structural BMP's for stormwater storage and treatment, regular maintenance of existing stormwater control devices, and increased 
frequency of street sweeping. The Comprehensive Plan also recommends that the city develop policies for protecting the quality of receiving water bodies and retrofit water quality improvement techniques into existing drainage systems.

\section{Stormwater Management}

While there is some debate about the parameters of the discipline, the American Society of Civil Engineers (1992) has defined stormwater management as "the conceptualization, planning, design, construction, and maintenance of stormwater control facilities". Some practitioners define the field more inclusively, as all governmental actions undertaken to control storm runoff and its causes (Hawley and McCuen, 1987; Pyzoha, 1994). Stormwater management (or drainage) programs have traditionally focused on the disposal of stormwater and flood control, with an emphasis on structural solutions. Only recently has mitigation of environmental impacts emerged as an important issue in the field of stormwater management (Lager et al., 1977; ASCE and WEF, 1992).

As nonpoint source contributions to the degradation of water resources have become more apparent, governmental agencies and researchers have attempted to characterize and address pollution conveyed by stormwater. In 1983 the US EPA sponsored the Nationwide Urban Runoff Program (NURP) which characterized pollutants occurring in urban runoff, based on data from runoff samples collected at various geographic locations around the country. Many other studies have since documented water quality problems resulting from pollutants conveyed by stormwater 
(ASCE and WEF, 1992; US EPA, 1993a). Best management practices (BMP's) employing both structural and non-structural approaches have been developed to manage stormwater quality. The use of BMP's to mitigate water quality problems has been required by various federal, state and local regulations. Regulations pertinent to stormwater management in Warwick will be discussed in Chapter Two.

For many stormwater management programs, the incorporation of water quality goals and requirements into existing programs has led to major institutional changes (Prince George's County, 1986; Stitt, 1986; Lindsey, 1988b; Shaver, 1988; Shea et al., 1993). Stormwater management has historically taken a lower priority than more immediately apparent infrastructure needs, such as water service, sanitary sewers, and road construction and repair. In many communities stormwater management was only initiated after severe flooding problems occurred (Tucker, 1976). Additionally, few local public agencies have been found to conduct an adequate operation and maintenance program for stormwater facilities (Poertner, 1981). Where institutional analyses of stormwater functions have been conducted, it has often been found that the assignment of responsibility for various stormwater management activities is unclear (Lindsey, 1988b). Introducing new, costly waterquality requirements into existing stormwater management programs has revealed many long-standing problems, which are usually related to inadequate resources (Poertner, 1981). 


\section{Objectives of the Study}

Warwick's stormwater management program is administered by the Department of Public Works (DPW). Like most stormwater management programs, it has been oriented primarily toward solving problems of stormwater quantity, with little attention thus far to water quality issues. Although Warwick's Comprehensive Plan and the Greenwich Bay Plan recommend that the DPW address stormwater quality problems, these plans have not identified the impact that implementing water quality practices will have on the existing program.

This study will analyze the existing stormwater management policies and activities in Warwick, identify changes that should be made to address water quality issues in the Greenwich Bay watershed, and assess the organizational and general financial needs that would result from those changes. The approach used to make this assessment is described in the following section.

\section{Approach and Method of the Study}

Numerous stormwater management programs have successfully implemented changes in goals and/or levels of service (Pince George's County, 1986; Stitt, 1986; Ferrari, 1987; Lindsey, 1988a; Shaver, 1988; Shea et al., 1993). These initiatives have often required extensive study and generally follow a rational method of decisionmaking often used by policy analysts (Morgan, 1984; Patton and Sawicki, 1993). The current study does not undertake to develop a complete plan for stormwater management. It seeks to assess the organizational and general financial needs that 
would result from changes in the existing stormwater management program to address water quality problems in the Greenwich Bay watershed.

This needs assessment will generally follow a step-by step rational approach to program analysis described by Morgan (1984). A rational approach is generally regarded as the standard or "textbook" approach to decision-making in public policy (Patton and Sawicki, 1993). Its advantages include: a step-by-step formula for problem-solving is more easily understood by observers than an incremental, unplanned approach (Quade, 1989); the rational approach is widely accepted by policy-makers and the general public (Morgan, 1984); and a rational process has been observed to enlighten policy decisions with information (Patton and Sawicki, 1993). Use of a rational approach to decision-making should be accompanied by recognition of its inherent disadvantages: adequate information is often lacking; there is generally insufficient time and money to analyze all relevant information; and community or individual values are difficult to analyze rationally.

Methodology to assess organizational and financial needs was developed from Morgan's approach to program analysis. It will be conducted using the following steps: 1) a clear definition of major stormwater quality problems will be made, along with a statement of goals and objectives for improving water quality, 2) current stormwater management activities will be identified, 3) possible changes in the stormwater management program and their expected levels of effectiveness will be described, 4) impacts potential program changes could have on the existing program 
will be assessed, and 5) setting priorities will be discussed, along with possible funding sources and organizational structures. These steps are explained below.

\section{Defining the Problem, Goals, and Objectives}

A clear definition of the local stormwater problem should be used as a basis for formulating attainable goals and objectives for a local stormwater management program (Shaver, 1988; Montgomery Watson, 1994). Defining the stormwater quality problem in the study area will involve reviewing all available water quality data, obtaining the current understanding of stormwater's role in Greenwich Bay's pollution problems, and itemizing regulations that affect stormwater quality. Flooding problems in the Greenwich Bay watershed will also be noted so as to state the water quality problem in the context of other program needs. Necessary information will be obtained through reports of water quality testing, interviews with state and local officials, and regulatory documents. The results of this research will be reported in Chapter Two.

\section{Assessing Current Activities}

Identifying the extent of current stormwater management policies and activities will help determine what additional policies and activities would be beneficial to address water quality issues (Stitt, 1986; Lindsey, 1988b). This assessment will also provide insight regarding how new initiatives could be integrated into Warwick's existing stormwater management program. Interviews with local 
officials and a review of the city's Comprehensive Plan, Capital Improvement Program, and other documents will be conducted. Findings of this assessment will be reported in Chapter Three.

\section{Itemizing Possible Program Changes}

Actions to mitigate nonpoint source pollution should be matched with a watershed's unique situation (Tucker, 1976; Montgomery Watson, 1994; Terrene Institute, 1994). Criteria will be developed to identify management practices bestsuited to solving identified problems in the study area. A list of potentiallyappropriate BMP's will be developed, based on authoritative sources of information regarding stormwater management practices for water quality. These sources will include publications by the American Public Works Association (1991), American Society of Civil Engineers and Water Environment Federation (1992), US EPA (1993a), US EPA and NOAA (1993), RIDEM and RI CRMC (1993). The listing of BMP's will include a brief description and summary of advantages and disadvantages for each practice. This information will be presented in Chapter Four.

Assessing Impacts on Existing Program

Anticipated benefits of changes in stormwater management practices should be evaluated in the context of their financial and organizational impacts on the existing stormwater management program (Heaney, 1988; Field, 1991). A preliminary set of BMP's that appear to most fully meet selection criteria identified 
in Chapter Four will be selected from the comprehensive list described in Chapter Four. Information regarding organizational requirements and general costs of these activities will be obtained from secondary sources and interviews with state and local officials. Based on available data, assessments will be made of potential organizational and financial impacts that recommended changes could have on Warwick's stormwater management program. Results of these assessments will be presented in Chapter Five.

\section{Identification of Priorities and Funding Sources}

In an environment with limited resources and many needs, priorities must be set in keeping with the defined problem and community needs (Tucker, 1976; Heaney, 1988). Criteria will be recommended for setting priorities for the implementation of water-quality-related stormwater activities. These will be based on earlier identification of the stormwater problem, as well as recommendations for stormwater management priority-setting made by the APWA, ASCE and WEF, US EPA, and City of Warwick. Possible sources of funding for proposed changes in stormwater management practices will be researched and explained, as will organizational structures for stormwater management programs. These topics will be addressed in Chapter Six. 


\section{Chapter Two \\ Defining the Stormwater Quality Problem in the Study Area}

The stormwater management program administered by Warwick's Department of Public Works (DPW) focuses primarily on the resolution of flooding problems and the removal of stormwater from streets and property (Sheahan, 1995). The purpose of this chapter is to describe known water quality problems in Greenwich Bay and to assess the extent to which these problems could be appropriately addressed by the existing stormwater management program of the City of Warwick.

A clear definition of the local stormwater quality problem is essential to setting attainable water quality goals and objectives for a stormwater management program (Shaver, 1988). This problem will be defined by reviewing the primary pollutants known to affect Greenwich Bay and their probable relation to stormwater, stormwater management, regulations, and the goals and resources of the existing stormwater management program. This chapter will also examine the potential for community support of stormwater management for water quality. The resultant definition of the local stormwater quality problem will provide the basis for setting attainable stormwater quality goals and objectives.

\section{Water Quality Problems in Greenwich Bay}

Studies conducted by RIDEM and the FDA have identified bacterial contamination as the most significant water quality problem in Greenwich Bay (RIDEM, 1988a; 1990; 1992; 1994b; FDA, 1994). Additionally, severely depressed 
levels of dissolved oxygen have also been recorded in Apponaug Cove. One of Greenwich Bay's five coves, it has a surface area of 0.2 square miles. The ratio of bottom organisms to sediment is low throughout Greenwich Bay, and particularly low ratios occur in Apponaug and Greenwich Coves (RIDEM, 1988a; 1990; 1992; 1994b).

Many diverse pollutants are carried into Greenwich Bay by stormwater runoff (RIDEM, 1988a; City of Warwick, 1994b). Since concern for the bay has been mobilized by limitations of use (City of Warwick, 1994b), this study will focus on those pollutants most likely to be associated with the loss of uses.

\section{Bacterial Contamination}

Detection and treatment of stormwater runoff that has been contaminated by human waste prevents communication of infectious diseases, such as gastroenteritis and hepatitis-A. These diseases can be communicated through consumption of raw shellfish from polluted waters (Brock and Madigan, 1991). Contamination by pathogenic organisms is often measured by counts of fecal coliform, a type of bacteria which occurs naturally in the intestinal tracts of warm-blooded animals and humans. While fecal coliforms are generally not etiological agents of disease, their presence in water samples indicates the potential for pathogenic bacteria or viruses to be detected ${ }^{1}$.

RIDEM has classified the waters of the state, designating the use or uses which they may accommodate (RIDEM, 1988b). For each classification RIDEM has

\footnotetext{
1 A good review of the adequacy of fecal coliform counts as an indicator of viruses is found in Buzzard's Bay Project 1991.
} 
developed criteria for determining whether individual water bodies have attained water quality standards necessary to support the designated uses. Fecal coliform counts are one criterion used in making these determinations. Acceptable levels of fecal coliform in shellfishing waters are based on National Shellfish Sanitary Program (NSSP) standards. The FDA has observed that from 1984 to 1992 Greenwich Bay never stringently met NSSP standards in winter months, due to high fecal coliform counts (FDA, 1994). Current use classifications and levels of attainment for Greenwich Bay are presented in Table 2.1.

Table 2.1. Greenwich Bay Use Classification and Attainment

\begin{tabular}{lll}
\hline Area within Bay & Classification & Attainment \\
\hline Apponaug Cove & SC & Not supporting \\
Brush Neck Cove & SB & Not supporting \\
Greenwich Cove & SC & Fully supporting \\
Warwick Cove & SB & Threatened \\
Remaining Area & SA & Conditionally approved \\
\hline
\end{tabular}

$\mathrm{SA}=\quad$ shellfish harvesting for direct human consumption, bathing and primary contact recreation, fish and wildlife habitat. $\mathrm{SB}=\quad$ shellfish harvesting for human consumption after depuration, bathing and primary contact recreation, fish and wildlife habitat.

$\mathrm{SC}=$ boating and other secondary contact recreation, fish and wildlife habitat, industrial cooling, good aesthetic value. Source: RIDEM, 1994b.

\section{Nutrient Problems}

Low levels of dissolved oxygen in Apponaug Cove have been attributed to high levels of nutrients in runoff (RIDEM, 1988a; 1990; 1992; 1994b). Apponaug Cove has failed to support SC uses, due to hypoxic (low oxygen) and anoxic (lack of oxygen) conditions, especially during the summer months when algae growth rates 
peak. High nutrient inputs are also a likely cause of low organism-sediment values in benthic environments throughout Greenwich Bay, and particularly in Apponaug and Greenwich Coves (RIDEM, 1990; 1992; 1994b). An additional deleterious effect of nutrients is algal growth, which is often regarded as a nuisance by the general public.

The introduction of large amounts of nutrients into a water body can lead to eutrophic conditions and decreased concentrations of dissolved oxygen. High nutrient inputs stimulate lush and rapid growth of aquatic plants, particularly algae. An over-abundance of aquatic plants results in high respiration rates and the decay of large quantities of plant material, thus creating a high biological oxygen demand (BOD). The depletion of dissolved oxygen stresses aquatic organisms and renders the environment unsuitable for many species. Marine environments tend to be nitrogen-limited, and fresh-water environments phosphorus-limited. This means that nitrogen inputs generally stimulate lush plant growth in marine waters, and phosphorus has this effect on fresh bodies of water. Mitigating BOD and algal growth in Greenwich Bay will require reduction of nitrogen inputs. Reduced phosphorus inputs will limit plant growth in the bay's tributaries, which is expected to have a positive -- though less direct -- impact on the bay.

\section{Sediment Problems}

Although they are not inherently toxic, large deposits of sediments can smother bottom organisms (Whipple, 1991). Sediment also transports pathogens, 
nutrients, and metals to receiving waters (Horsley and Witten, 1994). Effects of sedimentation on stormwater facilities are of particular concern to stormwater management programs. Large volumes of sediment in runoff increase the need for maintenance and contribute to structures' failure, which can result in flooding problems.

\section{Nonpoint Source Pollution and Stormwater}

As explained in Chapter One, nonpoint source pollution originates from many diffuse sources and is carried by rainfall or snowmelt. In undeveloped areas naturally-occurring pollutants are carried by runoff into stream channels and water bodies. However, natural drainage systems are usually in equilibrium (ASCE and WEF, 1992) and allow for treatment of pollutants. As runoff moves through vegetated areas, plant cover slows the rate of flow and filters out larger solids. Water is detained in depressions, allowing suspended solids to settle. Some runoff seeps into the soil, where processes occur which neutralize certain dissolved pollutants. Runoff is also used by plants, some of which assimilate various dissolved pollutants (Horsley and Witten, 1994).

Urbanization disrupts this natural equilibrium. Pollutant loads increase. Impervious surfaces inhibit processes which treat pollutants, while increasing the amount and rate of runoff (Lazaro, 1979; ASCE and WEF, 1992). 


\section{Bacterial Contamination and Stormwater}

Bacterial contamination is typically found in urban runoff (US EPA, 1983; 1993a; Whipple, 1991). Microorganisms are generally transported by runoff as dissolved pollutants, but they can also be carried by sediments (Horsley and Witten, 1994). Bacterial contaminants are known to originate from the following sources:

- $\quad$ surface ponding from septic systems that are malfunctioning or are sited in poor soils, areas with high water tables, and areas with high population density;

- groundwater infiltration into stormdrains from malfunctioning or improperlysited septic systems;

- $\quad$ illicit discharges of sanitary waste to natural or manmade drainage-ways;

- groundwater infiltration from leaking sewer pipes; and

- animal waste from agricultural operations, pets and wildlife.

The FDA has identified seven direct, priority sources (streams and stormdrains) of bacterial pollution to Greenwich Bay (FDA, 1994). RIDEM is sponsoring a study, which will be completed in Spring 1995, of the largest identified contributor, Hardig Brook. In the Summer of 1995, the City of Warwick will sponsor a study of pollution loadings to two other significant contributors identified by the FDA study (Baker Creek and Tuscatucket Brook). The Hardig Brook study has already identified a direct discharge of wastewater from a renovated mill building. There is evidence that other, small point sources -- such as illicit discharges or failing septic systems -- can be identified and corrected (Adamowicz, 1995).

Septic systems may contribute significantly to the bacterial problem. There 
are approximately 6,200 housing units in the study area, at least 5,000 of which are not sewered (City of Warwick, 1994b). Properly-functioning septic systems generally allow for adequate treatment of pathogenic bacteria and viruses. However, where many systems are used on neighboring lots smaller than one-acre, the soil's capacity for treating pathogens may be exceeded (Canter and Knox, 1985). Other factors which may prevent adequate treatment of pathogens from septic systems include high water tables and soils which are not suitable for septic systems (SCS, 1961; Canter and Knox, 1985).

Bacterial contamination also enters receiving water bodies from direct discharge of waste from boats. This source is being addressed by RIDEM with federal funding of pump-out stations that will serve Greenwich Bay. Decreases in discharges of marine waste will benefit the bay. These discharges, however, are of greatest concern in summer months during peak recreational boating use (US EPA, 1993a). Since Greenwich Bay's most severe fecal contamination problems generally occur in winter months during wet-weather events (FDA, 1994), contributions from boat discharges appear to be of less significance than land-based sources.

\section{Nutrients and Stormwater}

Nutrients commonly occur in urban runoff (US EPA, 1983). They originate from natural organic material, atmospheric deposition, fertilizer application, waste from pets and wildlife, improper disposal of yard waste, and septic systems -- even systems appropriately sited and properly maintained (Horsley and Witten, 1994). 
Agricultural operations that do not implement best management practices can contribute major amounts of nutrients to runoff (US EPA, 1993a). A few farms still operate in the Greenwich Bay watershed in Warwick.

Nitrogen, the major nutrient of concern in marine waters, is generally transported by runoff in dissolved form, while phosphorus often adheres to sediments. Dissolved nitrogen from properly-functioning conventional septic systems leaches through the soil, often partially oxidized to nitrates or nitrites. Denitrifying bacteria in waterlogged soils may convert nitrates and nitrites to gaseous form $\left(\mathrm{N}_{2}\right)$. This function of waterlogged soils is not a practical means of treating septic effluent, however, since systems tend to fail in poorly-drained soils (Henry and Heineke, 1989). Most often, nitrogen from septic systems is not denitrified as it enters the groundwater and eventually flows into surface waters. Phosphorus from septic systems, on the other hand, adheres to soil and usually does not present a problem for groundwater or surface water bodies that receive groundwater.

\section{Sediment and Stormwater}

Construction sites with improper soil erosion and sediment control practices contribute the most significant amounts of sediment to runoff (Bartlett, 1981; ASCE and WEF, 1992). Also contributing to this problem are: sanding and salting of roads in winter, lawn-care and gardening practices, and agricultural practices. While the pollution problems documented in Greenwich Bay have not been directly attributed to sediment inputs, reduction in these inputs would reduce stress on stormwater 
management facilities, reduce maintenance costs, and may help decrease nutrient and pathogen problems.

\section{Pollution and Stormwater Management}

Stormwater structures designed for efficient removal of water from streets and property can contribute to water quality problems (Tucker, 1976). This is due to accelerated rates of flow, increased volumes of water, and the bypassing of natural processes that treat pollutants in runoff.

As mentioned in Chapter One, various structural "best management practices" (BMP's) have been developed to treat stormwater quality problems. In general these BMP's take advantage of natural purifying processes, including filtration, infiltration, settling and biological assimilation. The appropriateness of structural practices depends on the pollutant(s) to be controlled and the land uses in the catchment area (Whipple, 1991; Horsley and Witten, 1994).

Non-structural BMP's are also used to address nonpoint source pollution. These practices generally attempt to control pollution at its source, rather than treat pollutants after they enter the stormwater system. Where possible, source controls are preferred to structural controls (Schmidt and Spencer, 1986; Whipple, 1991). Non-structural practices include: maintenance of structural BMP's, training of local officials or contractors regarding construction and maintenance of structural BMP's, regulations for new development, public education regarding the importance of

stormwater facilities, maintenance and repair of septic systems, preservation of 
pervious areas, street sweeping, and many other activities (US EPA, 1993a).

As with structural BMP's, the appropriateness of non-structural practices depends on the pollutant(s) to be controlled and the land uses in the catchment area (Whipple, 1991; Horsley and Witten, 1994). Site-specific information may also be required to select the most appropriate non-structural BMP's (Schmidt and Spencer, 1986).

\section{Stormwater Management Regulations}

The U.S. Congress and the Rhode Island Legislature have passed laws directed at mitigating impacts of nonpoint source pollution. Some of this legislation will affect Warwick's stormwater management program.

\section{Federal Regulations}

The 1987 reauthorization of the federal Clean Water Act required operators of certain stormwater facilities to obtain National Pollution Discharge Elimination System (NPDES) permits for these facilities. Parties required to obtain these permits include municipalities with a population of 100,000 or more and eleven categories of industrial facilities. The US EPA has delegated to the State of Rhode Island the responsibility of regulating these discharges through a state program, the Rhode Island Pollution Discharge Elimination System (RIPDES), which is administered by RIDEM. The US EPA is expected to issue further regulations for controlling stormwater discharges of communities under 100,000. The expected content of the 
forthcoming regulations has not been made public.

RIDEM's Division of Water Resources issues RIPDES permits to industrial facilities. Among the categories of industrial facilities, the regulations require a RIPDES permit for construction activities which disturb five or more acres of land. The permitting process involves the development of a Stormwater Pollution Prevention Plan (SWP3) for each permittee. SWP3's emphasize the use of nonstructural BMP's.

The federal Coastal Zone Act Reauthorization Amendments of 1990 require coastal states to develop nonpoint programs for designated coastal areas (referred to as 6217 (g) programs) and submit them to NOAA and US EPA by July 1995. Stormwater management will be one of the main focuses of $6217(\mathrm{~g})$ programs. The entire state of Rhode Island has been designated a coastal area, and RI CRMC is currently preparing Rhode Island's 6217 (g) program, with assistance from RIDEM. The program will be submitted by July 1995 and is expected to focus on requiring various BMP's for new development (Boyd, 1995). State programs are scheduled to go into effect upon receipt of final federal approval. However, it is possible that the new Congress will delay implementation of these programs (Boyd, 1995).

\section{State Regulations}

Rhode Island state laws require RI CRMC and RIDEM to review and issue permits for development that meet specific criteria. RI CRMC reviews plans for any project within 200 feet of coastal features, and large projects within the boundaries 
of Special Area Management Plans, to assess the impact of proposed development on coastal waters. RI CRMC's definition of "large projects" is given in Section 300.6.A.7 of Addendum to the State of Rhode Island Coastal Resources Management Program (RI CRMC, 1993). Among other development projects, the definition includes subdivisions of six or more units. RI CRMC currently requires stormwater management practices for most projects and requires an annual total suspended solids (TSS) loading reduction of $80 \%$.

RIDEM's Division of Wetlands reviews plans and issues permits for development in or near wetlands. Wetlands regulations are intended to protect wetlands from alterations that are random, unnecessary and undesirable. Reviews are designed to determine whether a proposed alteration to or near a wetland is random, unnecessary or undesirable. Reviews also determine whether an alteration's impact would be significant or insignificant. These reviews do not necessarily address specific stormwater management practices. Rule 7 and Appendix 2 of RIDEM's Rules and Regulations Governing the Administration and Enforcement of the Freshwater Wetlands Act (RIDEM, 1994a) provide guidance in determining whether a proposed activity will require a wetlands permit.

\section{Local Regulations}

Local governments are authorized under the 1992 Rhode Island Land Development and Subdivision Review Enabling Act to set standards for stormwater management. This Act also specifies that protection of the natural environment is 
a legitimate public purpose. At present, Warwick's Subdivision Regulations require that the DPW review stormwater management plans for all new development in the city. These reviews will be discussed in greater detail in Chapter Three, but their purpose is to protect public safety by mitigating stormwater quantity.

RIDEM's Office of Environmental Coordination and Rhode Island Soil Conservation Districts are developing a Model Stormwater Ordinance. By adopting this ordinance, a community could establish and provide for the enforcement of local regulations for the operation and maintenance criteria for stormwater management systems. The model ordinance will address issues of water quantity and quality for stormwater management of new development. It is intended to help communities mitigate stormwater pollution from development not subject to RIPDES, RI CRMC or wetlands reviews (Millar, 1994).

\section{Implications of Regulatory Framework}

There are no regulations requiring the City of Warwick to take any action to address stormwater quality for existing development. Forthcoming NPDES/RIPDES regulations for communities of less than 100,000 are expected to require municipal action, but the nature of the requirements is not known at this time. Certain projects undertaken by the city, including improvements of existing roads, are subject to RI CRMC and/or RIDEM reviews. Certain types of new, private development in certain areas of Warwick are also subject to RI CRMC and/or RIDEM reviews. These reviews generally require proper quantitative and qualitative management of 
stormwater quality.

The city currently requires new development to manage stormwater quantity. There is currently no mechanism to require stormwater quality management for new development that is not subject to RI CRMC or RIDEM reviews. There is also no requirement for upgrading existing stormwater facilities -- whether publicly or privately owned -- to address water quality.

\section{Stormwater Quality, Existing Resources and Goals}

Clearly defining the stormwater quality problem in the Greenwich Bay watershed in Warwick should be put in context of the community's current goals and allocation of resources for stormwater management. Stormwater management in Warwick has been organized around solving water quantity problems. It appears that addressing water quality problems will require additional resources, or some reallocation of existing resources.

Recommendations for changing current practices should be tempered by evidence that the program's current funding resources may be inadequate to fully address water quantity problems. Improvements to the stormwater management system are made reactively, as flooding problems occur. At present there are a handful of unresolved flooding problems in various sections of the city, scheduled for correction this year (Villella, 1995a). While the DPW recognizes that flooding problems can often be prevented by a comprehensive system of stormwater improvements, financial resources have not been available to develop a 
comprehensive drainage improvement plan since the 1970s (Sheahan, 1995).

A further limitation to proactive, preventive stormwater management is a reduced capacity to maintain existing facilities, due to shortages of funding and manpower (City of Warwick, 1991; Sheahan, 1995). Chapter Three will review the allocation of resources to stormwater management.

\section{Community Perceptions of the Stormwater Problem}

Pyzoha (1994) has observed that stormwater management programs cannot successfully address a situation unless the community perceives it as a problem and supports its solution. Research has shown that the public perceives water quality problems largely in terms of use restrictions (Heaney, 1988). It is outside the scope of this study to scientifically survey community perceptions of Greenwich Bay's water quality problems, although such information would be useful in developing a comprehensive watershed protection program (Heaney, 1988; Pyzoha, 1994; Terrene Institute, 1994). In the absence of scientific survey information, public and political support can be estimated, by reviewing statements of public officials and public records, such as election results.

Prior to the closure of Greenwich Bay to shellfishing, the bay's pollution problems were not a political issue in Warwick. After the 1992 closure to shellfishing, a bond referendum designating $\$ 5$ million to projects to benefit the bay was approved by $70 \%$ of the voters. Exit polls indicated that, if $\$ 3$ million for asbestos removal had not been tacked onto the "bay bond", the approval margin 
would have been greater (Stevens, 1994). Warwick Mayor, Lincoln Chafee, has stated that the unconditional re-opening of Greenwich Bay to shellfishing is a "top priority" of his administration (City of Warwick, 1994f). Since shellfishing in Greenwich Bay has been limited by bacterial contamination, mitigation of this pollutant has strong potential for community support.

While the costly effects of sediment loading on stormwater facilities are recognized by the DPW, the public has not perceived sediment as a pollution problem (Villella, 1995a). At this time, Apponaug Cove appears to be the only portion of Greenwich Bay where there is a direct link between nutrients and failure to attain water quality standards. Unfortunately, this cove is not widely used or viewed by the public. Although it is within 500 feet of a bustling village center, the cove is not visible from the main roads, sidewalks, or other frequently-used public areas. Unaesthetic algal growth and loss of species in this cove may be noticed by the few individuals that live or work in buildings immediately adjacent to Apponaug Cove. However, these problems are unlikely to concern the general public unless there is an increased awareness of Apponaug Cove.

Although governmental action should be taken in response to public demand, defining water quality problems in terms of public perception has serious disadvantages. The public is unlikely to understand technical stormwater problems caused by sediment loadings. Ignoring sediment problems can result in excessive stormwater management costs and increased flooding problems, as well as environmental degradation. Although some residents may regard abundant algal 
growth as a pollution problem, the public is not likely to perceive or understand the early warning signs of hypoxia, anoxia and low organism-sediment values. Failure to address nutrient inputs at this stage may result in severe restrictions on use of the bay in the future.

Planning for the public sector often requires that a balance be struck between responsiveness to urgent problems and prevention of future problems (Forester, 1989). The implications of failure to address sediment and nutrient problems indicates that these pollutants should not be removed from stormwater quality considerations.

\section{Statement of Stormwater Quality Problems}

To define the stormwater quality problem in the Greenwich Bay watershed in Warwick, this chapter has reviewed: water quality information, the role of stormwater in transporting major pollutants, the potential for stormwater management to address these pollutants, pertinent regulations, the goals and resources of the existing stormwater management program, and the potential for community support of stormwater quality management. This review indicates that the stormwater quality problem should defined in terms of three pollutants.

Bacterial contamination of shellfish areas appears to be the primary water quality problem. However, this problem may be better addressed by source controls than stormwater management structures. Some of these practices may be appropriately implemented by the stormwater management program, and others may 
be more appropriately implemented by other local programs. Chapter Four will provide a thorough analysis of BMP's to mitigate bacterial contamination and the appropriate agencies to implement them.

Sediment will be considered a secondary problem, due to its impact on stormwater facilities, its capacity for transporting pathogens and nutrients, and its potential impact on the benthic environment. Nitrogen will be considered a tertiary problem. This pollutant is ranked lower than sediment primarily because the scope of dissolved oxygen and algal problems appears to be limited at present. A second reason for ranking sediment as a higher priority than nitrogen is the fact that reduction of sediment inputs reduces some maintenance requirements for stormwater management structures. Reduction of nutrients does not have a similar benefit to stormwater management programs, which indicates that there may be a greater imperative for mitigating sediment than nutrients in stormwater.

Nitrogen is not omitted from consideration, though, since it could potentially cause wider-spread restrictions on use of the bay. Although it seems likely that phosphorus loadings have negative effects on the bay, it will not be considered a priority pollutant. This choice was made partly to limit the complexity of analysis, but also because the effects of phosphorus on marine waters are less direct than those of nitrogen, and the mitigation of sediment will likely reduce phosphorus loadings. Chapter Four will provide an analysis of appropriate non-structural and structural BMP's to treat sediment and nitrogen problems, with particular emphasis on BMP's which accomplish multiple purposes. 


\section{Stormwater Quality Goals and Objectives}

Once a stormwater quality problem is defined, it can provide a basis for formulating attainable water-quality goals and objectives for a local stormwater management program (Shaver, 1988; Montgomery Watson, 1994). Goals tend to be general statements which describe a desirable future outcome, while objectives are oriented toward translating goals into specific action (Patton and Sawicki, 1993). This study will suggest goals and objectives the city may wish to adopt in order to address the above-defined stormwater-quality problem. Suggested goals to accomplish this are:

- Implementation of non-structural and structural best management practices designed to mitigate bacterial contamination, sediment inputs, and nitrogen inputs, for critical developed areas within the Greenwich Bay watershed.

- Implementation of policies for new development which would mitigate bacterial, sediment and nitrogen inputs to stormwater, within the Greenwich Bay watershed.

Action-oriented objectives for accomplishing the

identified goals are outlined below. This study will offer guidance for implementing some of these objectives, as indicated. Suggested objectives are:

1) Identification of appropriate $\mathrm{BMP}^{\prime} \mathrm{s}$, which offer the most effective mitigation of bacterial contamination at least costs. And, where possible, identification of BMP's which also mitigate sediment and nitrogen inputs. See Chapter Four.

2) Assessment of organizational requirements and costs associated with implementing BMP's in critical areas. See Chapter Five.

3) Identification of sources of funding needed to accomplish stormwater quality goals. See Chapter Six. 
4) Identification of priority areas, with guidance from water quality studies of Hardig Brook, Baker Creek and Tuscatucket Brook. Not within scope of this study.

\section{Conclusion}

Introducing stormwater quality goals to Warwick's stormwater management program is not intended to replace the traditional focus on managing quantity, but to supplement it. Failure to manage stormwater quantity can directly threatened human life and property (City of Warwick, 1991). In the Greenwich Bay watershed, failure to manage stormwater quality can result in significant damage to the public welfare. Social impacts of poor water quality include loss of economic activity, loss of recreational uses, potential decreases in property values, and potential health hazards of swimming in a polluted bay or eating contaminated shellfish.

In summary, neither quantity nor quality goals for stormwater management in the Greenwich Bay watershed should be omitted. However, where financial resources are limited, priority should be given to problems that directly threaten human life and property. 


\section{Chapter Three Description of Current Stormwater Management Program}

This chapter identifies the existing stormwater management policies and activities of the City of Warwick. The information presented here will provide the basis for developing recommendations for changes in stormwater management to help relieve water quality problems identified in Chapter 2 .

The structure of this program description is patterned after an inventory of stormwater management activities prepared by Hawley and McCuen (1987). The following sources were also used in structuring this chapter: American Public Works Association (1991); Florida Department of Environmental Management (1993); Prince George's County (1986), Lindsey (1988b); Washington County, Oregon (no date); and Pyzoha (1994).

This description will first identify the authority for stormwater management, the purpose of stormwater management, and guiding policies. Subsequently, public and private stormwater management activities will be examined according to functional category. Finally, staffing and financial resources of the public stormwater management program will be discussed.

\section{Statement of Authority to Manage Stormwater}

Like most communities in the U.S., Warwick manages stormwater both directly by installing and maintaining stormwater facilities and indirectly by setting standards for stormwater management on private property. Authority for direct and 
indirect stormwater management flows from different sources. Authority to construct and maintain public stormwater facilities is provided by Warwick's City Charter. It states that the Department of Public Works is responsible for "the functions and services relating to highways, engineering, street lighting, public parking lots, waste disposal, ... and such other public works activities as may be defined by ordinance" (City of Warwick, 1960). The DPW is to have charge of the construction, reconstruction, alteration, repair, maintenance, operation, and engineering relating to the several functions and services within its jurisdiction. Although the charter does not specifically mention drainage or stormwater management, the DPW's responsibility for highways and parking lots has necessitated management of stormwater runoff.

Warwick's authority to set standards for stormwater management practices on private property is derived from the Rhode Island Zoning Enabling Act of 1991, the Rhode Island Land Development and Subdivision Review Enabling Act of 1992 (or Development Review Act), and the Rhode Island Sediment and Erosion Control Act. The Zoning Enabling Act requires municipalities, through a zoning ordinance, to "designate appropriate drainage requirements and methods to manage stormwater runoff" (RIGL 45-24-33 [A] [4] [h]). The Development Review Act authorizes municipalities to set design and improvement standards in local subdivision regulations that may include standards for drainage systems and soil erosion control (RIGL 45-23-45 [A]).

The Sediment and Erosion Control Act provides a model ordinance that 
municipalities may enact to control sediment and erosion. It enables municipalities to require and enforce implementation of sediment and erosion control plans for certain activities that disturb the local terrain. Sediment and erosion control plans are to include provisions for stormwater management. Warwick has enacted the model sediment and erosion control ordinance.

\section{Purpose of Stormwater Management in Warwick}

No mission statement has been articulated for Warwick's stormwater management activities that is separate from the City Charter's general assignment of responsibilities to the DPW. However, the Services and Facilities component of the city's Comprehensive Plan identifies priorities for the DPW's construction of stormwater management improvements. The local Zoning Ordinance, Subdivision Regulations, and Sediment and Erosion Control Ordinance outline purposes for which the city may set stormwater management standards for private development.

A review of these documents -- along with interviews of DPW and DOP staff -- indicates that the purpose of stormwater management has been to protect public safety by controlling the quantity of runoff. The Mayor and City Council have endorsed the Greenwich Bay Plan, which calls for implementing stormwater management practices to help mitigate the effectso of nonpoint source pollution on Greenwich Bay. Officials of the DPW and DOP have also expressed interest in addressing stormwater quality issues. However, the focus of stormwater management remains on quantity. A review of city documents that describe the purposes of 
stormwater management in Warwick follows.

The Comprehensive Plan

The Services and Facilities component of the Comprehensive Plan provides an overview of the activities and organization of public stormwater management in Warwick. The portion of this overview that is closest to a statement of purpose for stormwater management is a listing of the DPW's criteria for setting priorities for stormwater capital improvements. These criteria are presented in Table 3.1. Except for a criterion that addresses the unaesthetic appearance of mud and debris, these criteria do not include water quality considerations.

Table 3.1. Criteria for Prioritizing Stormwater Capital Improvements Projects should be undertaken that would correct:

1 a threat to public safety, such as icing or severe ponding so as to cause traffic accidents;

2 a threat to public health such as through basement flooding so as to contribute to disease, fire, electric shock, or other injurious events;

3 a threat to property such as through flooding of yards and dwellings resulting in damage or loss of personal and real property;

4 adverse impacts on aesthetics such as severe ponding and puddling of muddy water and debris;

5 general nuisance such as slow draining systems; and/or

6 many and frequent complaints.

Source: City of Warwick, 1991. 
The Zoning Ordinance

The city's Zoning Ordinance was revised in 1994, in compliance with the 1991 Zoning Enabling Act. The purposes for which the ordinance was designed include the following statements that are relevant to the incorporation of water quality goals into the stormwater management program:

- to provide for the control, protection, and/or abatement of ... water ... pollution, and soil erosion and sedimentation (Section 103.4).

- $\quad$ to provide for the preservation and promotion of ... aquaculture, ... and open space (Section 103.6).

- to provide for the protection of public investment in ... stormwater management systems (Section 103.7).

Although these purposes would support inclusion of water quality standards for private stormwater management, the stormwater standards outlined by the ordinance (Section 604.5) primarily address quantity of stormwater runoff. These will be discussed later in the chapter.

\section{Subdivision Regulations}

Warwick's current Subdivision Regulations have not yet been revised to comply with the 1992 Development Review Act. Among the purposes for creating the existing regulations, which were adopted in 1988 , the statement "to conserve natural beauty and other natural resources" (Section 1.1) would provide a basis for establishing measures to protect stormwater quality. Like the Zoning Ordinance's stormwater requirements, the Subdivision Regulations relating to stormwater management (Section 2.6.1) are aimed at controlling stormwater quantity problems. Specific 
policies will be discussed later in this chapter.

The state's 1992 Development Review Act identifies purposes for which municipalities may issue subdivision regulations. One of these purposes which would support the establishment of standards for stormwater quality is:

promoting the protection of the existing natural and built environment and the mitigation of all significant negative impacts of any proposed development on the existing environment" (RIGL 45-23-30 [3]).

\section{Sediment and Erosion Control Ordinance}

One of the findings on which this ordinance is based identifies sediment as "a major water pollutant". This finding would support the establishment of stormwater quality standards for the sediment and erosion control plans that this ordinance requires.

\section{Stormwater Management Policies}

Components of the public stormwater system are to be designed for a minimum of a 25-year storm. DPW construction projects follow practices outlined in the Rhode Island Soil Erosion and Sedimentation Handbook (RIDEM and RI CRMC, 1993) to minimize sedimentation and erosion. Construction of roads and other public projects is to result in zero net increase of runoff. The city's Zoning Ordinance requires that new development be designed so as to result in zero net increase of runoff, based on a minimum of a 25 -year storm. 


\section{Description of Stormwater Management Activities}

This section is divided into two parts. First, activities associated with the public stormwater management system will be outlined. This will be followed by an overview of activities which regulate private management of stormwater.

\section{The Public Stormwater Management System}

Inventory. The location, size and type of existing public stormwater management facilities are recorded on plat maps by the Engineering Division of the DPW. Information regarding public and private "stormwater holding structures"1 is also recorded using computer spreadsheet software. An explanation of this system - and records as of April 1,1995 -- are included in this report as Appendices 4 and 5. In the past, installation of stormwater facilities occurred without standard recordkeeping procedures. Although current records show all recently-installed facilities, and the majority of older facilities, they are not complete. Locating and mapping stormwater management facilities is an ongoing project. The Engineering Division has observed that a geographical information system (GIS) would be of great assistance in recording locational, and other, information about the components of the stormwater system (Villella, 1995b).

Long-Range Planning. Funding of capital improvements to augment or replace the city's stormwater infrastructure is provided to the DPW through the Capital Improvement Program and Budget (CIPB), which is required by the City Charter and

\footnotetext{
${ }^{1}$ Includes detention and retention basins, drywells, leaching chambers, and infiltration basins.
} 
administered by the Planning Department. The CIPB lists the priorities of all necessary capital improvements according to the city's fiscal ability to meet them during a six-year period. It specifies the amounts of funds to be allocated during each of six fiscal years to each department of the city for capital expenditures. The projects financed by the CIPB are items which cannot be financed through current city revenue and are therefore financed by issuing bonds.

The CIPB does not specify which stormwater projects should be undertaken, rather, each fiscal year the Director selects projects using criteria listed previously in Table 3.1. Capital improvements are generally made to correct drainage problems that have already occurred, rather than to prevent them. Where possible the DPW attempts to coordinate stormwater construction or repair projects with road construction or repair. If capital improvements to the stormwater system are combined with highway projects, priority is given to stormwater needs (Sheahan, 1995).

In the 1970s Warwick had a master stormwater management plan prepared for the city by C.E. Maguire, a planning and engineering firm. This plan identified necessary improvements to the city's stormwater management system and provided a schedule for implementation. However, it is outdated, and no similar plan has since been developed. The DPW Director and Assistant City Engineer have observed that a master plan would provide guidance for strategic selection of capital improvements (Sheahan, 1995; Villella, 1995a). This would better enable the department to construct capital improvement projects to prevent stormwater 
problems, a more cost-effective strategy than correction of existing problems (ASCE and WEF, 1992).

Project Design and Construction. The Engineering Division designs new stormwater management structures. Staff members of both the Engineering and Highways Divisions of the DPW construct them.

Public Maintenance \& Operations. The DPW has a policy of inspecting and performing routine maintenance of stormwater facilities on an annual basis. A list of the procedures conducted during these inspections is included as Appendix 6 . Two members of the Highways Division are assigned full-time to drainage maintenance and response to complaints. In the 1970 s there were six crews (twelve individuals) assigned to this task. However, over the last 20 years budget constraints have resulted in a gradual downsizing of maintenance staff.

The goal of annual inspection and maintenance of each stormwater structure may not be fully met, due to staffing limitations. The crew is responsible for recording which facilities they have inspected and maintained. However, there is no protocol for ensuring these records are kept. Careful documentation of stormwater maintenance -- while it may impose on the time the crew can spend maintaining structures -- would help the DPW determine the extent to which additional resources should be dedicated to the maintenance effort.

Sediment and vegetation are not routinely removed from detention basins. DPW officials have expressed concern that this maintenance procedure would violate RIDEM restrictions on disturbance of areas with wetlands values. The Rhode Island 
Wetlands Act does, however, specifically allow "routine maintenance" of wetlands plants in stormwater facilities. It is important to note that when build-up of sediment and vegetative material is not removed, the hydraulic capacity of detention basins is reduced. This leads to the failure of basins to manage stormwater quantity or quality (Whipple, 1991).

The routine inspection and maintenance of stormwater structures does not include natural components of the stormwater system. Until the mid-1980s the DPW had a full-time, three-man crew responsible for removal of obstructions to brooks and natural channels. Due to budget constraints and concern about RIDEM wetlands regulations, staff are no longer assigned to this task. At present this work is only performed in response to complaints.

Street Sweeping. The DPW has a policy of sweeping all city-owned streets twice a year. However, due to time and equipment constraints, sometimes they are swept only once. Sweeping usually occurs in the Spring, to remove winter sand and salt. The Highways Division operates two street sweepers, and two Highways staff members operate these vehicles.

Response to Complaints. The Engineering Division takes complaints, sends out a crew to identify the problem, and determines the best approach to solve it. Before a work order is issued, the Director must approve it. A tracking system records each complaint and the work order issued in response to the problem. These records are filed in hard-copy and on a computer database, according to city ward and address. When a new complaint is registered, a staff member checks the database to see 
whether it is a recurrent problem.

Public Involvement. The DPW has occasionally conducted public surveys regarding stormwater management service (City of Warwick, 1991). The most recent survey was conducted in the 1970s. The primary way in which the public has been involved in Warwick's stormwater management program has been through registering complaints. The Engineering Division places a priority on timely and thorough responses to complaints.

\section{Role in Private Stormwater Management}

Review of New Development. A DPW review of drainage plans for new development is triggered by one of the following actions initiated by a property owner (or designee):

1. An Application for Physical Alteration (such as curb removal or installation) is filed with the DPW.

2. An Application for Permit to Subdivide Land is filed with the Department of Building (DOB).

3. An Application for Building Permit is filed with the DOB, and the DOB requests a DPW review.

4. A Soil Erosion and Sediment Control Plan is submitted to the DOB, and the DOB requests a DPW review.

Applications for physical alteration and subdivision of land automatically require a stormwater management review. Stormwater management reviews of building permit applications and soil erosion and sediment control plans are requested at the DOB's discretion. The DOB, or the Department of Planning, 
generally requests that the DPW conduct a stormwater management review after receiving a building permit application for a "large" project. Developments are generally considered large if they involve 20,000 to 30,000 square feet of impervious surface (DePasquale, 1995). However, no formal definition has been made for determining which building permit applications require a stormwater review. Table 3.2 provides a comparison of the administrative actions which may require stormwater management reviews.

Table 3.2. Comparison of Actions that May Require Stormwater Management Review

\begin{tabular}{lllll}
\hline Activity & $\begin{array}{l}\text { Dept. } \\
\text { Accepting }\end{array}$ & $\begin{array}{l}\text { SWM } \\
\text { Review? }\end{array}$ & Fee? & $\begin{array}{l}\text { Approval } \\
\text { Expires? }\end{array}$ \\
\hline App. Phys. Alt. & DPW & Required & No & No \\
Subdiv. App. & DOB & Required & No & 1 year \\
Bldg. Pmt. App. & DOB & $\begin{array}{l}\text { at DOB } \\
\text { discretion }\end{array}$ & Yes & No \\
Sed.\& Eros. Plan & DOB & $\begin{array}{l}\text { at DOB } \\
\text { discretion }\end{array}$ & No & 1 year \\
\hline
\end{tabular}

Fee Structures. An Application for Building Permit requires a fee, based on the valuation of construction costs. The collection of this fee is authorized by the City Charter. The current schedule of building permit fees is included as Appendix 7. The other application and plan submissions do not require a fee. However, the state Development Review Act authorizes the collection of fees for subdivision reviews, and the Sediment and Soil Erosion Control Act authorizes the collection of fees for plan reviews. 
Waivers. There is no official procedure for obtaining a waiver of SWM requirements. However, stormwater management reviews provide latitude for developers and engineers to negotiate how requirements will be met.

Plan Modifications. Hawley and McCuen (1987) have recommended that stormwater management review procedures include guidelines to be followed in the event a developer modifies plans after they have been approved. The DPW has not formally set such guidelines. However, once construction is completed, the City Engineer or Assistant City Engineer requires the developer to submit a copy of the construction plans certifying the plans are as-built in accordance with specifications approved by the Planning Board and Engineering Division.

Expiration of Permits or Approvals. Sedimentation can be reduced by setting a finite time within which construction must be completed (Hawley and McCuen, 1987). Permits to subdivide land expire one year after date of approval if the approved plat has not been recorded with the City Clerk, or an extension has not been granted by the Planning Board. Approval of Soil Erosion and Sedimentation Plans expires one year after approval, if approved construction has not been completed, or an extension has not been granted by the Building Official. Building permits and approval of applications for physical alteration have no provision for expiration.

Revocations and Suspensions. The revocation or suspension of permits or approvals is a tool by which the government can stop work that is not proceeding according to approved plans (Hawley and McCuen, 1987). Procedures for revocation 
and suspension of Soil Erosion and Sediment Control Plans have been outlined by the Soil Erosion and Sediment Control Ordinance. No such procedures are specified for physical alterations, building permits, and permits to subdivide land.

Construction Bonds. Construction bonds are required of developers prior to issuance of permits to subdivide land. These bonds are administered by the Department of Planning. After construction has been completed, approval by the City Engineer or Assistant City Engineer is required before a bond may be released.

Design Criteria. The DPW has not specified criteria by which developer should accomplish Warwick's policy of "zero net increase in runoff" from pre-development to post-development conditions. The Engineering Division reviews each site plan and calculates whether proposed drainage provisions will accomplish zero net increase. Where drainage plans fail to meet this standard, the Engineering Division may suggest methods for better controlling stormwater. The DPW has incorporated RIDEM stormwater management policies into the review of private stormwater management practices.

The case-by-case approach to stormwater reviews has resulted in varied levels of stringency applied to developments. The DPW and the DOP have recognized that specifying more explicit criteria for stormwater design would result in better attainment of the zero-net-increase goal. The zero-net-increase policy is partly intended to mitigate potentially harmful effects on adjoining property and to control sediment and erosion problems. The DOP is considering setting specific standards for controlling sediment and erosion in the new subdivision regulations. 
The current review procedures do not specify that structures should be designed to facilitate maintenance. However, engineering staff will at times suggest design techniques that anticipate maintenance needs.

The outcome of reviews is currently a stamp of approval of construction plans. The reviews do not require a developer to submit a plan or program for maintenance. Maintenance may be discussed during the review process, but there is no formal statement of what type of maintenance should be conducted, nor the frequency of maintenance activities.

The DPW currently requires that detention basins designed to contain two or more feet of standing water should be enclosed by a six-foot fence. If the fence is not gated, it can pose an obstacle to maintenance.

Inspections. The City Engineer or Assistant City Engineer inspects construction sites periodically. Such inspections do not have a standardized protocol, and are generally made without prior notice. At completion of construction a final inspection is made. This provides the basis for the City Engineer or Assistant City Engineer's notice of approval to the Department of Planning. If construction does not meet with DPW approval, the developer will be requested to correct problems.

Private Maintenance. Responsibility for stormwater maintenance can be conceptualized as consisting of two components: financial and administrative (Hawley and McCuen, 1987). The party with financial responsibility pays for actual maintenance procedures. The party with administrative responsibility ensures that maintenance is done satisfactorily. In Warwick, the DPW has financial and 
administrative responsibility for the publicly-owned system. It also takes over financial and administrative responsibility for detention basins in residential developments. Prior to accepting these responsibilities, the DPW ensures the facilities have been built according to approved plans.

After construction of commercial developments, both financial and administrative responsibility for stormwater management facilities are placed on the owner. There is no provision for enforcement if a developer does not uphold these responsibilities.

\section{Allocation of Resources for Stormwater Management}

Stormwater management activities that pertain to public stormwater management facilities are conducted by the Engineering and Highways Divisions within the DPW, and overseen by the DPW Director. Stormwater management activities pertaining to private development are conducted primarily by the DPW Engineering Division, with some involvement of the DOP and the DOB. A review of staffing and financial resources allocated to stormwater management will help determine where changes might be made to address water quality issues.

\section{Staff Assignments}

Brief summaries are given below of the staffing assignments for stormwater management by the DPW, DOP, and the DOB.

The Director of the DPW. The Director's role in stormwater management 
consists primarily of: 1) approval of work orders to repair drainage problems, 2) determining which stormwater capital improvement projects should be undertaken.

Stormwater management is a small element of the Director's responsibilities. The DPW consists of seven divisions: Administration, Highways, Recycling, Automotive, Building Maintenance, Engineering, and Water. The Director oversees the operations of the entire department, which has a staff of 175 . When considering what resources to allocate toward stormwater management, the Director must weigh the relative needs of many, varied activities.

DPW Engineering. The Engineering division's role in stormwater management consists of: 1) taking complaints, 2) managing tracking system of repairs, 3) issuing work orders, 4) advising the Director in selection of capital improvement projects, 5) designing stormwater management facilities, construction of stormwater management facilities -- in cooperation with Highways staff, 6) review of stormwater management plans for private development, 7) inventory of stormwater management facilities.

This division consists of five staff members, including the City Engineer, who is chief of the division. Stormwater management is only one of the division's numerous responsibilities. The Engineering Division designs streets and sidewalks, as well as stormwater projects. It is also responsible for street lighting.

DPW Highways. This division's role in stormwater management consists of: 1) conducting annual maintenance of drainage facilities and responding to drainage problems (two employees are assigned to this task full-time), 2) construction of 
stormwater management facilities, and 3) street sweeping (two employees are assigned to this task once or twice a year).

The Highways Division consists of 79 staff members, including the division Chief. Its primary focus is to construct and maintain the city's streets. There are 450 miles of city-owned streets in Warwick. This division responds to complaints regarding the repair of streets and follows a constant maintenance protocol of street condition.

Department of Planning. This department is generally responsible for facilitating orderly growth of the city. It is also responsible for writing the city's Comprehensive Plan, Zoning Ordinance, and Subdivision Regulations. Stormwater management is addressed by each of these documents. The DOP reviews applications for building permits and subdivision of land to ensure compliance with the comprehensive plan, zoning, and subdivision regulations. This department may advise the Building Official that a stormwater management review should be conducted for large developments. It also administers construction bonds for new development.

Building Department. This department issues permits for building and subdivision of land, and it evaluates soil erosion and sedimentation plans. The Building Official determines whether a review of stormwater management facilities by the DPW is necessary for the issuance of a building permit or the approval of a soil erosion and sedimentation plan. The Building Official inspects construction projects to ensure adherence to building codes and soil erosion and sedimentation 
plans. These inspections generally do not include stormwater management facilities.

\section{Budget for Stormwater Management}

Capital and operational expenditures are treated separately by the city government. The Capital Improvement Program and Budget designates specific funding for stormwater management projects. The city's annual budget for operational expenditures is divided first by department, then by division. Operational expenditures for stormwater management are difficult to separate from expenditures for other activities conducted by the various departments and divisions involved in stormwater management.

Operational Budget. Since the DOP and DOB allocate very small amounts of staff time to stormwater issues, this section will attempt to review the financial resources allocated by the DPW's operational budget to stormwater management. This will be accomplished by examining budgets for the DPW's Engineering and Highways Divisions, and making assumptions regarding the resources allocated to stormwater management.

For Fiscal Year 1994-95 (beginning on July 1), the Engineering Division's total operational budget was $\$ 908,327$. About three-fourths of that amount was allocated to street-lighting commodities. Personnel expenditures accounted for just under one-fourth of the budget. The remaining amount (less than 3\%) was allocated to commodity expenditures, such as drafting supplies.

To make a conservatively high estimate of the resources allocated to 
stormwater management, it will be assumed that stormwater management-related activities require $25 \%$ of the division's staff time. It will also be assumed that $25 \%$ of the commodities budget (after street lighting expenditures) are directed toward stormwater management. Calculations are presented on Table 3.3.

In Fiscal Year 1994-95 the Highways Division's total operational budget was $\$ 2,899,926^{2}$. Personnel expenditures accounted for over $70 \%$ of the budget, commodities over $20 \%$, and services about $6 \%$.

To make a conservatively high estimate of resources allocated to stormwater management, it will be assumed that personnel resources dedicated to stormwater management account for $5 \%$ of the personnel budget. This amount translates to approximately 4.95 full-time staff members. That would be sufficient to include two full-time drainage maintenance staff, as well as approximately twelve staff members dedicating $25 \%$ of their time to such stormwater management activities as street sweeping and construction of capital improvements. To make a rough estimate of resources allocated to stormwater management, it will also be assumed that $5 \%$ of commodities and services are directed toward stormwater management activities. The results of these calculations based on these assumptions are presented in Table 3.3.

Capital Budget. Capital improvements budget for stormwater management provides funds specifically directed for stormwater projects. The capital improvement budget for FY $1994-95$ was $\$ 400,000$. This has been allocated to a handful of

\footnotetext{
2 The Highway Division also generated $\$ 110,000$ in revenue, which is not included in this total budgeted amount.
} 
Table 3.3. Estimates of Operational Budgets for Stormwater Management (SWM), FY 1994-95

\begin{tabular}{|c|c|c|c|}
\hline Item & Engineering & Highway & Entire DPW \\
\hline Total Budget ${ }^{1}$ & $\$ 897,727$ & $\$ 2,899,926$ & $\$ 8,866,213$ \\
\hline$\%$ of DPW Budget & $10.13 \%$ & $32.71 \%$ & $100 \%$ \\
\hline Total \$: Personnel & $\$ 198,327$ & $\$ 2,133,926$ & Not Avail. \\
\hline $\begin{array}{l}\text { Assumed SWM \% of } \\
\text { Personnel }\end{array}$ & $25 \%$ & $5 \%$ & N.A. \\
\hline $\begin{array}{l}\text { Est'd \$ for SWM } \\
\text { Personnel }\end{array}$ & $\$ 49,582$ & $\$ 106,696$ & $\$ 156,278$ \\
\hline $\begin{array}{l}\text { Total \$: Com-modities \& } \\
\text { Svcs }\end{array}$ & $\$ 710,000$ & $\$ 874,000$ & N.A. \\
\hline $\begin{array}{l}\text { Assumed SWM \% of } \\
\text { Comm'ties \& Svcs }\end{array}$ & $0.2 \%$ & $5 \%$ & N.A. \\
\hline $\begin{array}{l}\text { Est'd \$ for SWM } \\
\text { Comm'ties \& Svcs }\end{array}$ & $\$ 1,420$ & $\$ 43,700$ & $\$ 45,120$ \\
\hline $\begin{array}{l}\text { Total Estimate of } \$ \text { for } \\
\text { SWM Activities }\end{array}$ & $\$ 51,002$ & $\$ 150,396$ & $\$ 201,398$ \\
\hline
\end{tabular}

1 Does not include Departmental or Divisional revenues.

Source: City of Warwick, 1994d.

projects to correct existing drainage problems. As the end of FY 94-95 approaches,a list of priority projects for FY 1995-96 has already been developed.

CIPB funds are allocated to stormwater management projects according to bonds that have been approved by public referendum. A bond referendum was passed in June 1994 that allocated $\$ 500,000$ to stormwater management studies for the Greenwich Bay watershed and $\$ 1,000,000$ to the implementation of structural best management practices to correct water quality problems in the Greenwich Bay watershed. Allocations of CIPB funds for stormwater management projects for the 
next six years are listed in Table 3.4. The availability of capital improvement funds beyond this horizon will depend upon the passage of future bond referenda.

Table 3.4. Capital Improvement Program and Budget Funds for Stormwater Management Projects

\begin{tabular}{lrr}
\hline Fiscal Yr. & $\begin{array}{c}\text { 1994-2000 CIPB } \\
\text { Allocation }\end{array}$ & $\begin{array}{c}\text { 1995 } \\
\text { "Bay Bond }^{1}\end{array}$ \\
\hline $1994-95$ & $\$ 400,000$ & $\$ 0$ \\
$1995-96$ & $\$ 400,000$ & $\$ 0$ \\
$1996-97$ & $\$ 400,000$ & $\$ 500,000$ \\
$1997-98$ & $\$ 400,000$ & $\$ 500,000$ \\
$1998-99$ & $\$ 400,000$ & $\$ 0$ \\
$1999-2000$ & $\$ 500,000$ & $\$ 0$ \\
\hline TOTALS & $\$ 2,500,000$ & $\$ 1,000,000$ \\
\hline
\end{tabular}

1 Funds allocated for installation of structural best management practices by June 7, 1994 bond referendum. Sources: City of Warwick, 1994a; 1994c.

Necessary Equipment

Equipment required for stormwater management includes: pick-up trucks, backhoes, front-end loaders, clamshell excavators for cleaning catch basins, stormdrain rooters, and street sweepers. The DPW has sufficient equipment to support current stormwater management activities described in this chapter, including two streetsweepers. Increased frequency of street cleaning may require purchase of an additional sweeper. Increases in frequency or scope of maintenance activities may also require purchasing additional equipment. 


\section{Conclusion}

This chapter has identified Warwick's stormwater management policies, activities, and the resources that support them. The following chapter will identify stormwater management practices that would help solve water quality problems known to occur in the study area. Chapter Five will then synthesize information about Warwick's stormwater management program (Chapter Three) and information about stormwater practices for water quality (Chapter Four).

The information presented in Chapter Three will provide insight into how changes to address stormwater quality could be integrated into the existing stormwater management program. It will also facilitate analysis of the relative ease with which various recommended changes could be made and demonstrate the extent to which resources are available to address water quality issues. 


\section{Chapter Four \\ Stormwater Management Practices for Water Quality Improvement}

As stated in Chapter One, the purpose of this study is to assess the organizational and financial needs that would result from the inclusion of water quality goals for the Greenwich Bay watershed in Warwick's existing stormwater management program. Assessing these needs requires an approximation of the most appropriate BMP's for the study area. The term "best management practice" (BMP) is used to describe one of any number of activities that may be used to mitigate nonpoint source pollution, as recommended by such sources as US EPA, RIDEM, and RI CRMC.

The purpose of this chapter is to identify a preliminary list of BMP's that are most appropriate to address stormwater quality problems in the study area, as defined in Chapter Two. Chapter Two established that bacterial contamination is the primary stormwater quality problem in this area, and sediment and nitrogen were identified as secondary and tertiary problems. BMP's will be identified that mitigate bacterial pollution and, where possible, also address sediment and nitrogen. It is important to note that more specific study should be conducted before implementing BMP's identified in this chapter, if the City of Warwick chooses to incorporate water quality goals into the local stormwater management program.

The chapter will begin with a review of procedures for selecting BMP's, followed by an explanation of the approach that will be used to identify appropriate BMP's for the study area. The balance of the chapter will consist of an inventory of 
specific BMP's that address problems identified in the study area. A brief explanation of each BMP will be provided, followed by a discussion of its advantages and disadvantages.

\section{Procedures for Selecting BMP's}

Stormwater management to address water quality problems is an emerging discipline. Innovations are continually being made in structural and non-structural BMP's, and strategies by which they are implemented (Schueler, 1994a). Many of these innovations result from recognition of weaknesses or gaps in program effectiveness.

Various methods for selecting BMP's have been used by different communities, with varied levels of success. Some communities have used a "piecemeal" approach, implementing individual non-structural or structural BMP's as opportunities arose. However, program evaluations suggest that designing a comprehensive system of BMP's can lead to more effective stormwater quality controls (Schueler, 1991; Schueler et al., 1991; Florida DEP, 1993).

The Piecemeal Approach

As local water quality problems are recognized, state legislation passed, or funding becomes available, communities often implement individual non-structural or structural BMP's. A major advantage to this approach is that some progress in stormwater management is made without waiting for comprehensive watershed 
studies. This approach is especially useful for communities that do not have financial resources available for comprehensive studies.

A key disadvantage to the piecemeal approach is that implementing individual structural or non-structural BMP's often has little effect on stormwater management problems (Hawley and McCuen, 1987; Schueler, 1991; US EPA, 1993c). Even if a community cannot sponsor a fully comprehensive watershed study, some effort should be made to coordinate implementation of BMP's (Buzzard's Bay Project, 1991).

\section{Comprehensive Watershed Strategies}

Research in stormwater management has consistently recommended a comprehensive approach to addressing water quality problems. Schueler (1991) has suggested that communities develop specific watershed-protection strategies to address problems associated with each phase of the land development process. He identifies specific practices and policies that protect water resources prior to development, during development, and after development has occurred.

Two major disadvantages associated with the comprehensive approach are the large amounts of time and money required to study the complexities of stormwater problems. Additionally, technical solutions do not always survive the political processes associated with implementation. Stormwater management plans may be shelved after they have been produced, due to lack of funds or political will to implement recommended BMP's. This was essentially the fate of Warwick's last comprehensive stormwater management plan. The majority of improvements 
studies. This approach is especially useful for communities that do not have financial resources available for comprehensive studies.

A key disadvantage to the piecemeal approach is that implementing individual structural or non-structural BMP's often has little effect on stormwater management problems (Hawley and McCuen, 1987; Schueler, 1991; US EPA, 1993c). Even if a community cannot sponsor a fully comprehensive watershed study, some effort should be made to coordinate implementation of BMP's (Buzzard's Bay Project, 1991).

\section{Comprehensive Watershed Strategies}

Research in stormwater management has consistently recommended a comprehensive approach to addressing water quality problems. Schueler (1991) has suggested that communities develop specific watershed-protection strategies to address problems associated with each phase of land development process. $\mathrm{He}$ identifies specific practices and policies that protect water resources prior to development, during development, and after development has occurred.

Two major disadvantages associated with the comprehensive approach are the large amounts of time and money required to study the complexities of stormwater problems. Additionally, technical solutions do not always survive the political processes associated with implementation. Stormwater management plans may be shelved after they have been produced, due to lack of funds or political will to implement recommended BMP's. This was essentially the fate of Warwick's last comprehensive stormwater management plan. The majority of improvements 
recommended were never implemented. However, when a comprehensive strategy for stormwater management is carefully constructed, and there is political will and funding to support its implementation, the comprehensive approach has proven superior to piecemeal BMP implementation (Pyzoha, 1994).

\section{Screening and Selection of Individual Practices}

Whether BMP's are implemented in a piecemeal fashion or as part of a comprehensive watershed approach, it is beneficial to identify a number of BMP's which are most appropriate to a community's unique circumstances (US EPA, 1993c). The US EPA (1993c) has recommended a two-step process for selecting BMP's appropriate to individual watersheds.

The first step is screening of BMP's. This step is intended to limit the sheer number of BMP's to be evaluated. It requires a literature search and/or consultation with experts to identify all possible BMP's. One or two preliminary criteria are developed and applied to screen out BMP's least likely to accomplish program goals. Such a screening process is usually conducted qualitatively, based on professional judgement.

The second step is selection of BMP's. Selection criteria, more stringent than the simple screening criteria, are developed. The list of BMP's that resulted from the screening process are used to develop alternatives, which can include combinations of source-control and structural BMP's. The US EPA then 
recommends a variety of methods for evaluating alternatives according to selection criteria.

Criteria. The US EPA recommends that communities use the following criteria to evaluate BMP's: 1) meets program goals, 2) cost, 3) operability, 4) buildability, 5) environmental effects, 6) public acceptance, and 7) institutional factors. Communities tailor these general criteria to their specific needs, and additional criteria are sometimes developed.

Evaluation Methods. A variety of quantitative and qualitative methods can be used to evaluate alternatives with multiple criteria (US EPA, 1993c; Patton and Sawicki, 1993). Qualitative assessments may be based upon professional knowledge of technical or political issues relevant to the local water quality problems. Quantitative methods often involve assignments of weight to various criteria and systems for scoring alternatives' levels of attainment for each criterion.

\section{Approach for Identifying Appropriate BMP's}

The approach for identifying BMP's appropriate for the study area will generally follow the steps recommended by the US EPA (1993c). This chapter will present the results of a BMP screening. Chapter Five will present results of the selection process.

BMP's have been screened based on the results of a literature search. Those listed in this chapter were determined to be 1) effective in mitigating the primary pollutant of concern, bacterial contamination, and 2) appropriate for the Department 
of Public Works to implement.

Many activities that are sometimes identified as stormwater management practices have not previously been conducted by Warwick's stormwater management program. Some of these practices are the responsibility of the Department of Planning, including subdivision review and site plan review. Other activities are primarily the responsibility of Department of Building, such as construction inspection and enforcement activities. Still others have not been the responsibility of any city agency. These include stormwater quality monitoring and public outreach.

The activities likely to be incorporated into the existing stormwater management program have been culled out from the others. It was assumed that activities appropriate to the DPW's stormwater management program include: 1) planning, design, construction, and maintenance of publicly-owned structural best management practices; 2) reviewing stormwater management plans for private development; and 3) some public outreach activities.

\section{Organization of BMP Listing}

BMP's will be listed in four categories, loosely based on phases of the development process identified by Schueler. This organization will facilitate the selection of BMP's that address the problems associated with various phases of development. The categories are described below.

1. Stormwater Planning Activities. Planning activities for the study area will also be identified. This includes developed and undeveloped land. 
2. Pre-development Reviews. Opportunities to guide the design of private developments to prevent stormwater problems will be identified. The items listed will be limited to those appropriate for the DPW to implement.

3. Resource Maintenance and/or Restoration. BMP's appropriate for developed watersheds will be identified. This includes both source controls and structural BMP's.

4. Structural BMP's for New Development. Structural BMP's appropriate for private and public stormwater management systems will be identified. These BMP's may be used in new development, or introduced into areas already developed.

\section{Explaining Advantages and Disadvantages}

To facilitate the selection of BMP's in Chapter Five, advantages and disadvantages of each BMP will be presented in terms of selection criteria. Although communities sometimes use additional criteria, the seven criteria recommended by the US EPA, and noted above, should prove sufficient for the limited purposes of this review. An explanation of how these criteria will be used follows.

1) Meets program goals. For the purposes of this study, BMP's will be evaluated according to whether they meet goals of mitigating pollutants of concern (bacterial contamination, sediment, and nutrients).

2) Cost. Low-cost alternatives are preferred to high-cost. Approximations of cost will be made. Assumptions and qualifications will be explained.

3) Operability. Primarily concerning structural BMP's, this criterion is satisfied by low levels of difficulty in implementation and operation, including maintenance.

4) Buildability. This criterion concerns structural BMP's. It is satisfied by low levels of construction constraints, such as site requirements and degree of difficulty.

5) Environmental Effects. This criterion is primarily a concern for structural BMP's. It is satisfied where positive effects BMP's may have on the surrounding environment outweigh the negative. 
6) Public Acceptance. This criterion is satisfied by apparent public support of a proposed BMP.

7) Institutional Factors. This criterion is met where authority to conduct activities is clear, and/or institutional commitment to a BMP is apparent.

Where operability, buildability and/or environmental effects are not applicable to non-structural BMP's they will be omitted. For each criterion of each BMP discussed, a brief qualitative assessment will be provided, based upon known problems in the study area and findings of stormwater management research. Each assessment will conclude with an estimation of whether the BMP satisfies the criterion, levels of satisfaction will include: full, adequate, marginal, or does not satisfy. These assessments will be used to make qualitative evaluations and a hypothetical selection of BMP's in Chapter Five.

\section{Stormwater Planning Activities}

It is generally cheaper and easier to prevent problems prior to development rather than correct them post-development. Stormwater management programs generally emphasize the need to implement non-structural BMP's that will guide the development of undisturbed areas, and serve to prevent water quality problems. However, since $69 \%$ of land in the study area is already developed (see Appendix 2), this category includes activities which involve planning for both developed and undeveloped areas. Activities will be listed in the order in which they are normally conducted. 
Stormwater Management Master Plan

The term "stormwater management master plan" has been used in various ways to describe various activities to prepare for future stormwater management infrastructure needs (ASCE and WEF, 1992). For the purposes of this study, a stormwater master plan will be assumed to include: inventories of the natural and man-made drainage systems, site-specific plans for improvements to the public stormwater management system, and a schedule and budget for improvements.

Meets Program Goals. The development of a stormwater management master plan has been recommended as effective in enhancing water quality, reducing flooding problems, and making use of financial resources more effectively than a piecemeal approach to stormwater management improvements (Poertner, 1981; ASCE and WEF, 1992; Beech, 1992; FL DEP, 1993). A master plan would enable the DPW to strategically implement structural BMP's throughout the watershed, to maximize effectiveness of mitigation practices for each drainage sub-basin. Level of criterion satisfaction: full.

Cost. Comprehensive planning activities can be very expensive. An inventory of natural areas alone for watershed protection planning in the City of Virginia Beach, Virginia cost approximately $\$ 84,000$ (US EPA, 1993a).

Stormwater management improvements recommended by a master plan are also expensive. Costs associated with specific structural BMP's are provided in the "Structural Best Management Practices" section of this Chapter. There should be a 
strong commitment to implementing a plan's recommendations. Level of satisfaction: marginal.

Environmental Effects. Comprehensive planning of a stormwater management system may enhance the environment by preventing nuisances. Level of satisfaction: adequate.

Public Acceptance. Developing a stormwater management master plan may be perceived as too expensive, unless the public perceives stormwater management as an important component of the quality of life. The public's favorable response to the "Bay Bond" referendum in 1994 indicates the level of satisfaction is adequate.

Institutional Factors. The city's Comprehensive Plan recommended that Warwick develop a stormwater management master plan (City of Warwick, 1991). However, funding sources for the cost of the plan, and ensuing improvements, must be identified. Level of satisfaction: adequate.

\section{Capital Improvement Program and Budget (CIPB)}

The DPW may consider including water quality enhancement of Greenwich Bay (or other valuable water resource) among the criteria for selecting stormwater capital improvement projects.

Meets Program Goals. This action would meet program goals insofar as projects include structural BMP's which effectively mitigate pollutants of concern in the study area. Level of satisfaction: full.

Cost. A very low-cost activity, since the CIPB project-selection process is 
already established. Level of satisfaction: full.

Operability. This change would be relatively easy to implement. Level of satisfaction: full.

Environmental Effects. A potential negative effect could occur if a water quality criterion were weighted too heavily. It might result in failure to implement projects for flooding relief. A higher priority should be placed on public safety than water quality. Level of satisfaction: adequate.

Public Acceptance. The public has been supportive of other projects to enhance Greenwich Bay water quality. Given this item's low cost, level of satisfaction is full.

Institutional Factors. There may be restrictions on use of CIPB stormwater funds. This possible obstacle to implementation results a satisfaction rating of adequate.

\section{Regional / Inter-jurisdictional Stormwater Management}

A Greenwich Bay Coalition has already been established. However, participation has primarily included Warwick and state officials. Since $22 \%$ of the Greenwich Bay watershed is occupied by other municipalities, the health of the bay is affected by many activities outside Warwick's jurisdiction. Collaboration with neighboring municipalities may be useful for implementing activities such as developing a stormwater master plan, construction and maintenance of regional stormwater facilities, training programs regarding BMP's, or sharing of personnel to 
review stormwater plans or conduct inspections.

In 1994 the Coastal Resource Center and Cooperative Extension of the University of Rhode Island led a watershed protection workshop for public officials of Hunt-Potowomut watershed communities. East Greenwich, North Kingstown, and Warwick officials participated in those workshops. A similar event for Greenwich Bay watershed communities, tailored to structural BMP's, could result in stronger cooperation.

Meets Program Goals. If cooperative efforts are built around program goals, they could be helpful in meeting these goals. However, neighboring communities seem more likely to participate in one-time workshops than continuous involvement. Criterion is adequately satisfied.

Cost. The cost of inter-jurisdictional meetings requires small amounts of staff time. Cooperative projects may actually save money, if they are projects the city would do anyway. Level of criterion satisfaction: full.

Operability. Warwick has invited representatives of other watershed communities to participate in Greenwich Bay Coalition meetings. Thus far, other communities have only participated occasionally in these meetings and other activities regarding Greenwich Bay. At present, the level of satisfaction appears to be marginal.

Public Acceptance. This activity would likely gain acceptance if it saves money. If it appears to be a waste of time it would not be acceptable. Level of satisfaction: adequate. 
Institutional Factors. Implementation of this BMP has complicated communication and cooperation aspects for the institutions involved. At present level of satisfaction appears to be marginal.

Geographical Information System (GIS)

The DPW Engineering Division has identified potential uses for a GIS, in recording site-specific information about stormwater management infrastructure. The Department of Planning has received a grant of $\$ 8,000$ to prepare specifications for a Greenwich Bay GIS. Experiences of other communities that use GIS's for stormwater management applications would be helpful in identifying specific stormwater applications for a GIS. References regarding stormwater applications listed in the bibliography include: Shea et al., 1993; Meyer et al., 1993; Wilson, 1993).

Meets Program Goals. GIS applications have been recognized as highly effective in analyzing stormwater runoff problems (Shea et al., 1993; Meyer et al., 1993) and managing infrastructure (Cowen, 1988). Level of satisfaction: full.

Cost. Purchasing and operating a GIS requires a sizeable investment of money and staff time. Costs associated with GIS applications far exceed the purchase price of hardware and software. Additional expenses include: feasibility studies prior to purchase, hiring of staff, training of existing staff, data collection, data structuring, attributing of information and input, and many other activities (Guptill, 1989). Costs of maintaining the system once it is established should not be 
overlooked in assessing the feasibility of implementing a GIS (Woodcock et al., 1990). Level of criterion satisfaction: marginal.

Operability. Staff thoroughly trained in use of GIS technology is essential, and start-up time may be lengthy. Level of satisfaction: marginal.

Public Acceptance. The Cooperative Extension of URI has found GIS to be a valuable tool in preparing public-outreach materials (Joubert, 1995). Although a GIS may be perceived as unnecessarily expensive, using this technology for multiple purposes (such as public outreach, planning, tax assessment, and public works) may result in public acceptance. Level of satisfaction: adequate.

Institutional Factors. The city's Greenwich Bay Plan has recommended purchase of a GIS to help manage water quality problems (City of Warwick, 1994b). The Department of Planning has taken considerable initiative toward obtaining a GIS. Opportunities for inter-departmental use of a GIS should be investigated, since by serving multiple uses, GIS costs can be shared by various units of government (Wilson, 1993). The criterion's satisfaction level for implementation by the DPW: not satisfied.

\section{Pre-development and Construction Activities}

This category of BMP's is directed largely at preventing urban runoff problems before land is developed. Although most of this watershed is already developed, land development restrictions can still prevent significant problems on the remaining developable land -- and on any land that may be redeveloped. The items in this 
category will be listed in the order in which they normally occur during the development process. Where activities may occur simultaneously, they will be listed in alphabetical order.

\section{Design Criteria}

A comprehensive and unambiguous set of design criteria are essential to meeting water quality goals of stormwater management reviews (Hawley and McCuen, 1987). Recommended elements of design criteria include: identification of design storm, a list of stormwater management practices a developer may use, performance standards, explanation of evaluation methods, design elements that will facilitate maintenance, and plans for maintenance. The State of Rhode Island Stormwater Design and Installation Standards Manual (or, State Stormwater Manual) establishes criteria that address each of these issues (RIDEM and RI CRMC, 1993). The manual is used by RI CRMC and RIDEM in their development reviews.

Warwick may choose to apply the stormwater manual design criteria to development in designated environmentally-sensitive areas. These criteria may be incorporated as an aspect of the Watershed Protection Overlay District, reserved as Section 312 of the Zoning Ordinance. If amending the Zoning Ordinance is not feasible, the Subdivision Regulations may be used to provide the Director of Public Works with authority to require or recommend practices outlined by the State Stormwater Manual for sensitive areas.

Meets Program Goals. Setting design criteria that address the primary 
pollutants of concern in the study area is the best way to prevent runoff pollution from new development (Hawley and McCuen, 1987; Schueler, 1991). Level of satisfaction: full.

Cost. This is a relatively low-cost activity. The Subdivision Regulations must be re-written to comply with the 1992 state Land Development Act, and the writing of specifications for the new overlay zone has already been planned. Incorporating more specific stormwater design standards into these documents will not require a significant amount of extra staff time. Stormwater reviews are already included in the subdivision permitting process. More specific design standards should not greatly affect the amount of staff time required per subdivision. Level of satisfaction: full.

Operability. Some training may be required to better acquaint engineering staff with water quality considerations for stormwater reviews. Criterion is fully satisfied.

Public Acceptance. Developers may be opposed to increased regulations. However, they may also welcome more specific design criteria that make the review process predictable. Level of satisfaction: marginal.

Institutional Factors. Writing the Zoning Ordinance and the Subdivision Regulations are responsibilities of the Department of Planning and the Planning Board. Communication between the DOP and DPW is essential to ensure an efficient and effective review process. Level of satisfaction: adequate. 


\section{Building Permit Review}

Warwick's Zoning Ordinance includes a provision that the building inspector can ensure compliance with storm and surface water drainage standards set forth in the ordinance, at his/her discretion, prior to issuing a building permit. The building official, in consultation with the DPW and DOP, could identify specific attributes of developments for which stormwater plans should be reviewed.

Possible models to consider include East Providence's Development Plan Review provisions or RI CRMC's definition of large projects. Within any zoning district, East Providence requires a development plan review for: 1) any exterior additions or changes to buildings or structures, or change of use which require the addition or deletion of twenty-five or more parking spaces, or 2) parking areas for twenty-five or more motor vehicles (City of East Providence, 1993). RI CRMC has a policy or reviewing developments that include one acre of parking (RI CRMC, 1990).

Meets Program Goals. Working with developers in the site-planning process is an important opportunity to mitigate harmful effects of numerous nonpoint source pollutants, including the pollutants of concern (RIDEM and RI CRMC, 1993; Whipple, 1991; Schueler, 1991). Level of satisfaction: full.

Cost. The amount of DPW staff time required to review stormwater plans would be likely to increase if the building official more consistently requests stormwater reviews for developments which meet certain criteria. Experience in the

Stormwater Division of the Maryland Department of Environment has demonstrated 
that one engineer can review approximately two stormwater management plans per day (Shaver, 1988). DPW staff has estimated that one engineer can review a stormwater management plan in one hour. To approximate the cost of person-hours for stormwater reviews, the total amount budgeted for personnel expenses within the Division of Engineering was divided by the number of Engineering staff members. This resulted in an average personnel cost of $\$ 36,000$ per employee. Assuming there are 250 work-days per year, a half-day review would cost $\$ 72$, and a one-hour review would cost \$18. Level of satisfaction: adequate.

Public Acceptance. Developers may object to more regular reviews of large projects. Use of highly specific criteria may increase predictability of such reviews, which is appreciated by developers. Use of the RI stormwater will reduce the number of different standards to which developments must comply. Level of satisfaction: marginal.

Institutional Factors. This activity would require the Building Official to standardize reviews that the Zoning Ordinance specifies are at the building official's discretion. Level of satisfaction: adequate.

\section{Development Plan Review}

The state 1991 Zoning Enabling Act enables municipalities to conduct development plan reviews of developments that are permitted by right under the local zoning ordinance (Section 45-24-49 [b]). Such reviews must be based on specific and objective guidelines set forth in the zoning ordinance. The forthcoming 
watershed protection overlay zone could require development plan reviews, with a particular focus on mitigating pollution from urban runoff. As mentioned in the section on building permit reviews, East Providence's provisions for development plan review could serve as a model.

Meets Program Goals. Development plan reviews would provide an opportunity for city officials to ensure proper steps are taken to mitigate pollutants of concern in runoff from certain new developments. Level of criterion satisfaction: full.

Cost. Warwick currently conducts development plan reviews for applications to amend the zoning ordinance. This process involves a pre-application conference prior to submission of the development plan. Development plan reviews are the responsibility of the Department of Planning. However, the DOP could request assistance from the DPW in reviewing stormwater management plans. Costs associated with development plan reviews would be the additional staff time required to conduct conferences and reviews. Level of satisfaction: marginal.

Public Acceptance. See the "Public Acceptance" section under "Building Permit Reviews". Level of satisfaction: marginal.

Institutional Factors. Initiating development plan reviews for a watershed protection zone would have greatest impact on the DOP. For the DPW to initiate implementation of this BMP, this criterion is not satisfied. 
Construction Inspections

Inspections have been recommended to occur at critical stages in the construction of structural BMP's, such as setting spillway crest elevations in construction of detention basins, and any construction that will be covered when construction is complete (Hawley and McCuen, 1987). Some jurisdictions require developers to notify the local inspector 24 hours in advance of such construction phases.

Meets Program Goals. This activity would advance program goals by ensuring proper construction of structural BMP's. Improperly construction can lead to failure of BMP's to mitigate pollutants of concern. Level of criterion satisfaction: full.

Cost. Costs would entail the time required by the city engineer, assistant city engineer, building official, or other staff member to inspect construction sites. Although inspections are already made, their frequency may be increased. Experience of the Stormwater Management Administration of the Maryland Department of Environment has demonstrated that inspectors, on average, inspect three construction projects per day for stormwater management and sediment control (Shaver, 1988). Using the same personnel cost assumptions made for calculating the costs of design review, each inspection would cost $\$ 48$ in staff time. Level of satisfaction: adequate.

Public Acceptance. Like other activities that affect developers, this could meet with some opposition. However, developers are often willing to comply with 
regulatory processes that are predictable and efficient. Level of satisfaction: marginal.

Institutional Factors. It should be determined whether stormwater inspections should be conducted by the Department of Building or Public Works. Experience of other communities has demonstrated that technical expertise in the functions of stormwater facilities is essential to effective inspection programs (Shaver, 1988; Coffman, 1994). As the number of structural BMP's increases, staff requirements increase (Shaver, 1988). Level of satisfaction: adequate.

\section{Resource Maintenance and/ or Restoration}

This section will inventory BMP's appropriate for areas that have already been developed. This will include activities suggested for maintenance of stormwater facilities and practices intended to remedy water quality problems. It has generally been acknowledged that preventing nonpoint source pollution is easier and less costly than correcting existing problems (US EPA, 1993a; RIDEM and RI CRMC, 1993; FL DEP, 1993). However, since a large proportion of the study area is already developed, it is essential to identify opportunities to correct problems in developed areas. Use of both structural and non-structural BMP's will be considered. Maintenance activities will be listed first, followed by restoration BMP's. Within each category items are in alphabetical order. 
Maintenance Inspections

As discussed in explanations of structural BMP's, proper maintenance is necessary to ensure that stormwater facilities achieve pollutant removal targets. Lack of maintenance is also the most common cause of their flooding (Pazwash, 1993). It has been observed that maintenance is frequently inadequate where private parties have both administrative and financial responsibility for maintenance of stormwater facilities (FL DEP, 1993; Hawley and McCuen, 1987). Thus, regular inspections should be conducted to ensure maintenance of private facility is properly performed.

Meets Program Goals. Maintenance inspections of private stormwater management facilities is an essential component of stormwater management for water quality. This practice helps ensure that non-public structural BMP's meet their pollutant-removal targets. Level of criterion satisfaction: full.

Cost. It has been the experience of the Maryland Department of Environment's Stormwater Administration that one inspector can inspect approximately three sites in one day (Shaver, 1988). Using the same personnel cost assumptions made for calculating the costs of design review and construction inspections, each maintenance inspection would cost $\$ 48$ in staff time. Level of satisfaction: adequate.

Public Acceptance. Like other activities that affect private development, this could have some opposition. It may be more acceptable if incentives for maintenance are offered, in addition to enforcement. Increased public awareness concerning the importance of maintaining stormwater facilities may increase the 
acceptability of this activity. Level of satisfaction: marginal.

Institutional Factors. Legal authority to inspect and enforce maintenance requirements would have to be established. The DPW would have to develop protocols for these inspections. Warwick can benefit from the experience of many other communities that have grappled with this issue. Maintenance inspection protocols of the following communities could serve as good models: Tallahassee, Florida (City of Tallahassee, 1993), and Prince George's County (Coffman, 1994). Training of staff would also be necessary. Level of satisfaction: adequate.

\section{Public BMP Maintenance}

As noted in Chapter Three, the DPW has both administrative and financial responsibility for maintaining public stormwater management facilities. Chapter Three outlined the existing maintenance program, which does not include certain activities that help mitigate water quality problems. Increased frequency of certain maintenance activities could also enhance water quality. As structural BMP's are incorporated into the public stormwater management system, these will also require maintenance, as described in previous descriptions of structural BMP's.

Meets Program Goals. It has been demonstrated that pollution mitigation capabilities are reduced substantially where proper maintenance does not occur (Galli, 1992; Schueler, Kumble, and Heraty, 1992). Thus, thorough and regular maintenance of public stormwater management facilities is an essential component of stormwater management for water quality. Level of satisfaction: full. 
Cost. The cost of increased maintenance activities can be estimated, based on increased staff time required. It may also be necessary to purchase additional equipment. To approximate the cost of labor for maintenance activities, the total amount budgeted for personnel expenses within the Division of Highways was divided by the number of Highways staff members. This resulted in an average annual cost of $\$ 26,000$ per person. Assuming 250-days per year and eight-hour work days, each additional hour of required maintenance will cost $\$ 13$ in staff time. Assuming that an additional pick-up truck is needed if two additional laborers are hired, a new truck should be purchased for every additional 4,000 hours of labor. The cost of a new pick-up can be estimated as $\$ 20,000$. Level of satisfaction: adequate.

Public Acceptance. The public is likely to welcome maintenance that results in apparent aesthetic enhancement or relief of flooding problems. However, there may be objections to the cost of maintenance. Increased public awareness of maintenance needs of stormwater management facilities can help alleviate this problem. Level of satisfaction: adequate.

Institutional Factors. More staff hours would have to be dedicated to maintenance of stormwater management facilities to provide for adequate maintenance of existing and future facilities. Level of satisfaction: adequate.

\section{Stormwater Quality Monitoring}

Evaluating the effectiveness of structural BMP's by monitoring water quality has been identified as a "critical component of a nonpoint source control program" 
(Clausen, 1991). Monitoring provides an opportunity to determine whether structural BMP's are achieving acceptable pollutant removal levels.

Meets Program Goals. This activity would help determine whether structural BMP's are meeting program goals. Level of criterion satisfaction: full.

Cost. Costs include laboratory testing and staff trained in water quality sampling. Although some work might be done by volunteers, it may be difficult to fund new activities. Level of satisfaction: marginal.

Public Acceptance. Citizen volunteers are already monitoring several points in the Greenwich Bay watershed. Level of satisfaction: adequate.

Institutional Factors. Although the Water Division and the Warwick Sewer Authority have facilities for water testing, it may be difficult to arrange for sets of testing. Level of satisfaction: marginal.

\section{Street Sweeping}

Some research has indicated that frequent street sweeping (from three to six times per year) has environmental benefits (US EPA, 1983; Sear and Wycoff, 1993; Pyzoha, 1994).

Meets Program Goals. While the aforementioned researchers have found that street sweeping can have positive results, effective removal of the pollutants of concern has not been consistently documented for this BMP. Results of the Nationwide Urban Runoff Program indicated that no significant reductions in pollutant loading are realized by street sweeping (US EPA, 1983). Hawley and 
McCuen (1987) have noted that it may be impossible to predict effects of street sweeping with any reasonable level of confidence using water quality models. Level of criterion satisfaction: adequate.

Cost. The total study area, including open water, comprises approximately 23 square miles, which is $65.7 \%$ of the city's total area (35 square miles, including water). Using the assumption that city streets in the study area comprise $65.7 \%$ of all city streets, it can be estimated that this area contains 295 miles of city streets.

Assuming all streets are swept twice a year, each additional sweeping of this area would require staff time equal to $32.8 \%$ of the staff time currently required annually. Assuming two staff members each dedicate one month per year to this task, and assuming personnel cost of $\$ 26,000$ per employee, the staffing costs associated with each additional sweeping would be $\$ 1,421$. More frequent sweeping may require purchase of a new sweeper. Level of satisfaction: marginal.

Environmental Effects. Beneficial effects of this activity include reduction of litter and debris in runoff. Level of satisfaction: adequate.

Public Acceptance. Where litter and debris have been an annoyance, increased frequency of sweeping may be welcome. Level of satisfaction: adequate.

Institutional Factors. Increased frequency of sweeping would require that additional staff hours be dedicated to this task. Level of satisfaction: marginal.

\section{Cross-connection Identification and Removal}

It has been recognized for many years that dry-weather flows in stormdrains 
may result from illicit discharges of residential, commercial, or industrial wastewater into the stormwater system (US EPA, 1983). Recent surveys have found such discharges to contribute significantly to stormwater pollution problems (Schmidt and Spencer, 1986; US EPA, 1993b). The US EPA has published a user's guide which outlines procedures for identifying and correcting these problems (US EPA, 1993b). These procedures generally require extensive mapping, field surveys, and water quality sampling.

Current research, sponsored by RIDEM, has identified at least one direct discharge of wastewater into a tributary of Greenwich Bay (Adamowicz, 1995). In the Summer of 1995, the City of Warwick will sponsor a study of pollution loadings to two other tributaries. Although this study is not a comprehensive search for cross connections, it will provide an opportunity to detect them in priority areas.

Meets Program Goals. The US EPA (1993b) has identified sanitary wastewater sources as among the most common sources of illicit discharges. Sanitary wastewater contributes large amounts of fecal coliform and nitrogen. A study in Washtenaw County, Michigan revealed, however, that chemical flows were much more significant than sanitary waste in that jurisdiction (Schmidt and Spencer, 1986). In the past some communities permitted, and even encouraged, cross-connections to stormdrain systems. If this was the case in Warwick, there are likely to be numerous illegal tieins. Level of satisfaction: adequate.

Cost. These surveys generally require a major commitment of staff time (Schmidt and Spencer, 1986). Laboratory analysis of water samples is also required. 
Criterion is not satisfied.

Operability. Before committing resources to a survey of cross connections, the city may wish to learn the results of ongoing and forthcoming scientific studies. Level of satisfaction: adequate.

Public Acceptance. No information available.

Institutional Factors. Different components of cross-connection investigations may be appropriate for different departments: the DOP may be best qualified for mapping, the DPW for field surveys, and the Sewer Authority or DPW Water Division for sampling. The complexity of this activity causes the level of satisfaction to be marginal.

\section{Structural BMP's: New Construction}

Non-structural BMP's are generally preferred to structural BMP's due to cost. In developed areas implementation of structural BMP's is rendered especially difficult and costly by the lack of available space. Because of these considerations, many stormwater management programs focus on constructing structural BMP's in developing areas. However, the amount of urbanized land in the area indicates a need for mitigation measures in existing development.

Meets Program Goals. Installing BMP's that have proven effective in reducing pollutants of concern would help advance program goals. This would be especially worthwhile in locations where nonpoint source problems have been pronounced. Level of criterion satisfaction: full. 
Cost. Construction and maintenance costs associated with specific BMP's are explained in the "Structural Best Management Practices" section of this chapter. Costs can be considerable. Level of satisfaction: marginal.

Buildability. Construction of BMP's in developed areas is often constrained by lack of space. Sand or peat filters have proven to be highly effective in areas where space is constrained. Level of satisfaction: marginal.

Public Acceptance. The positive public response to the 1994 "Bay Bond" referendum indicates level of criterion is adequate.

Institutional Factors. The city's Comprehensive Plan (City of Warwick, 1991) and Greenwich Bay Plan (City of Warwick, 1994b) have recommended retrofitting BMP's into the existing stormwater system. \$1 million is available for new construction or retrofits from 1995 to 1998 (City of Warwick, 1994a). Level of satisfaction: full.

Structural BMP's: Retrofitting

Existing stormwater management facilities may be retrofitted with BMP's. This may cost considerably less than installing a new BMP. Examples of retrofitting include: converting dry detention ponds to extended detention dry ponds or wet ponds, incorporating sand or peat filters in oil/grit separators or catch basins, and adding hydrophytic vegetation to existing dry ponds (Buzzards Bay Project, 1993; Coffman, 1994).

Meets Program Goals. This activity would meet program goals where existing 
facilities are converted to BMP's that have proven effective in mitigating pollutants of concern. Level of satisfaction: full.

Cost. Construction and maintenance costs associated with specific BMP's are cited in the "Structural Best Management Practices" section of this chapter. The amount by which those costs would be reduced for retrofits would vary from site to site. Level of satisfaction: adequate.

Buildability. Retrofits are often constrained by lack of open land. However, sand- or peat-filter BMP's can often be adapted to use small amounts of space (Schueler, 1994b, NVSWCD, 1994). Level of satisfaction: marginal.

Public Acceptance. The positive public response to the 1994 "Bay Bond" referendum indicates level of criterion satisfaction is adequate.

Institutional Factors. The city's Comprehensive Plan (City of Warwick, 1991) and Greenwich Bay Plan (City of Warwick, 1994b) have recommended retrofitting BMP's into the existing stormwater system. $\$ 1$ million is available for new construction or retrofits from 1995 to 1998 (City of Warwick, 1994a). Level of satisfaction: full.

\section{BMP's Eliminated by Screening}

A number of BMP's recommended for maintenance or restoration of water quality in developed areas have proven effective for addressing pollutants of concern, but seem inappropriate for the DPW's stormwater management program to conduct. These include: enforcing repair of failing on-site disposal systems; promoting 
reduced use of fertilizer, pesticides, and herbicides; animal waste reduction; and wetland restoration projects. These activities may be more properly conducted by the Departments of Building, Planning, or Parks and Recreation. Information about these BMP's is available in US EPA, 1993a.

\section{Structural Best Management Practices}

The structural BMP's listed in this section have proven effective in mitigating the pollutants of concern. Reviewing the advantages and disadvantages of these BMP's will assist the DPW in 1) recommending which BMP's should be used for private development in the study area, and 2) selecting which BMP's should be used for public projects in the study area. The descriptions provided below are brief and generally non-technical. A number of good BMP reference materials are listed in the bibliography. These include: RIDEM and RI CRMC, 1993; Schueler, Kumble, and Heraty, 1992; Griffin, 1993; and US EPA, 1993 a.

Structural BMP's will be listed according to effectiveness in mitigating bacterial contamination: from most effective to least effective. Where relative effectiveness is equal or unknown, BMP's will be ordered according to effectiveness in sediment and nitrogen mitigation. Where these are equal or unknown, items will be listed alphabetically.

\section{Wet Ponds}

Wet ponds are basins designed to maintain a permanent pool of water and 
temporarily store urban runoff until it is released at a controlled rate (Coffman, 1994). This basic structure may be enhanced by a forebay to trap incoming sediment where it may be easily removed, or by a fringe wetland. An enhanced wet pond differs from a constructed wetland in that an enhanced wet pond has less emergent vegetation and more standing water (Griffin, 1993).

Meets Program Goals. Studies have shown that wet ponds consistently achieve moderate to high levels of removal for both particulate soluble pollutants, including the three principal pollutants of concern for the study area (Galli, 1992; Griffin, 1993; US EPA, 1993a). Level of criterion satisfaction: full.

Cost. These structures have a relatively high cost of construction. They are more costly than dry basins, although dry basins are generally less effective in pollutant removal. Per-unit construction costs decline as size increases. Griffin (1993) has estimated that a wet pond with a volume of 100,000 cubic feet is capable of treating a drainage area of 50 acres. In this same study, construction of a 100,000 cubic-foot wet pond was estimated to cost $\$ 50,000$. Recent experience in constructing wet ponds in Rhode Island has indicated that construction of a wet pond capable of treating a 50-acre drainage area is more likely to cost $\$ 80,000$ (Spinnard, 1995). Maintenance costs of wet ponds range from $\$ 0.008$ to $\$ 0.07$ per cubic foot per year (US EPA, 1993a). The mean of these two amounts is $\$ 0.039$. Assuming a per-cubicfoot annual maintenance cost of $\$ 0.039$, the annual cost to maintain a wet pond of 100,000 cubic feet would be $\$ 3,900$. Level of satisfaction: marginal.

Operability. Moderate operability, if drainage area is greater than ten acres. 
Where drainage area is less than ten acres, standing water is depleted in dry months. Routine maintenance includes: annual inspections, mowing at least twice a year to remove woody growth. Trash and debris should also be removed regularly from the forebay (Griffin, 1993). Wet ponds may be temporarily drained in late spring and summer if mosquitoes are a problem. Level of satisfaction: adequate.

Buildability. Relatively low buildability. Wet ponds consume large amounts of space (as much as 1 to $3 \%$ of site). This BMP is most suitable for drainage areas over 10 acres. Soils should be relatively impermeable. Bedrock should not be close to surface. Wet ponds should be sited more than 50 feet from steep slopes. High water table is generally not a restriction (Griffin, 1993). Level of satisfaction: marginal.

Environmental Effects. Can provide aesthetic enhancement and warm-water fishery. May raise water temperature and lower oxygen levels in downstream water. May contaminate groundwater if water table is high. May cause mosquito problems. Potential safety hazard if not properly maintained. Level of satisfaction: marginal.

Public Acceptance. The public generally prefers wet ponds to dry ponds. However, mosquitoes may be a problem. Level of satisfaction: adequate.

Institutional Factors. DPW should either maintain or inspect to ensure maintenance occurs. The issue of RIDEM jurisdiction over stormwater facilities with wetlands vegetation should be resolved. Level of satisfaction: adequate. 
Constructed Stormwater Wetlands

Constructed stormwater wetlands are intended to simulate some functions of natural wetlands, particularly the water purification function (Griffin, 1993). They do not replicate all ecological functions of natural wetlands. They are similar to wet ponds, but there is more emphasis on vegetation, and a lower depth-to-area ratio.

Meets Program Goals. Studies have shown that constructed stormwater wetlands consistently achieve moderate to high levels of removal for both particulate soluble pollutants, including the three principal pollutants of concern for the study area (Galli, 1992; Griffin, 1993; US EPA, 1993a). A study by the New York Department of Environmental Conservation demonstrated that stormwater wetlands can remove 65 to $95 \%$ of fecal coliform in runoff, when residence time is five to seven days (Griffin, 1993). Level of criterion satisfaction: full.

Cost. Little information is available regarding costs associated with constructed stormwater wetlands (US EPA, 1993a; Griffin, 1993). However, it may be assumed that they are more costly to construct and maintain than wet ponds, since vegetation and area requirements exceed those of wet ponds. Griffin (1993) has reported an estimated construction cost range of $\$ 5,712$ to $\$ 80,769$ per acre. Maintenance costs have been estimated at $\$ 300$ to 500 per acre in the drainage area (Griffin, 1993). Assuming a constructed stormwater wetlands is $3 \%$ of its catchment area, fifty acres could be served by a 1.5 acre wetland. Using the cost range reported by Griffin, construction of this wetland would cost from $\$ 8,568$ to $\$ 121,153.50$, with a mean of $\$ 64,860.75$. Criterion is not satisfied. 
Operability. Constructed stormwater wetlands are generally less operable than wet ponds or ED dry ponds. They should be inspected periodically for the first couple of months, and annually once vegetation has stabilized. They should also be inspected after major storms. Debris and litter should be removed during inspections. Mowing should occur twice a year. Vegetation may need to be harvested periodically. Sediment should be removed approximately every five years (Griffin, 1993). Fish may be introduced to relieve insect problems. Level of satisfaction: marginal.

Buildability. Stormwater wetlands are relatively less buildable than ED dry ponds or wet ponds. They consume a considerable amount of space. Schueler, Heraty and Kumble (1992) have reported they require from a total surface area ranging from $1.5 \%$ to $5 \%$ of the drainage area (Griffin, 1993). Maryland has required that constructed stormwater wetlands comprise a minimum of $3 \%$ of the contributing drainage area (Livingston, 1988). Constructed stormwater wetlands are most feasible for drainage areas of greater than five acres. Relatively impermeable soils are most suitable for wetlands construction. Level of satisfaction: marginal.

Environmental effects. Can provide aesthetic enhancement and warm-water fishery. May raise water temperature and lower oxygen levels in downstream water. May contaminate groundwater if water table is high. May cause mosquito problems. Potential safety hazard if not properly maintained. Level of satisfaction: marginal. Public Acceptance. Mosquito problem may make this BMP unpopular. Level of satisfaction: marginal. 
Institutional Factors. The issue of RIDEM jurisdiction over constructed stormwater wetlands needs to be resolved. DPW should either maintain or inspect to ensure maintenance occurs. Criterion is not satisfied.

\section{Extended Detention (ED) Dry Ponds}

ED ponds are designed to temporarily detain a portion of urban runoff. Detention time is generally 6 to 24 hours after a storm. This allows solids and associated pollutants to settle out (Coffman, 1994). ED ponds do not have permanent standing water. They are typically designed with two stages: an upper stage which remains dry except for larger storms, and a lower stage which is designed for typical storms.

Meets Program Goals. Studies have shown that extended detention dry ponds can achieve moderate to high levels of removal for both particulate soluble pollutants, if they have been designed correctly. This includes the three principal pollutants of concern for the study area (Galli, 1992; Griffin, 1993; US EPA, 1993a). Galli (1992) has observed that design problems have caused ED ponds to be less effective in pollutant removal than wet ponds or constructed wetlands. Level of satisfaction: full.

Cost. Costs are lower than those of wet ponds. The US EPA (1993a) has provided the same range of construction costs for both ED and wet ponds. Randall and Krome (1987, cited by Griffin, 1993) have estimated that construction cost for ED ponds are from 7 to $11 \%$ higher than for dry ponds and from 16 to $57 \%$ lower 
than for wet ponds. Estimates of construction costs are provided in Table 4.1. Griffin (1993) has estimated that the average annual maintenance costs for a 100,000 cubic-foot ED dry pond would be $\$ 2,000$. Level of criterion satisfaction: adequate.

Table 4.1. Estimated Construction Costs for ED Dry Ponds

\begin{tabular}{|c|c|c|c|}
\hline \multirow[b]{2}{*}{$\begin{array}{c}\text { Storage Volume } \\
\left(\mathrm{ft.}^{3}{ }^{3}\right)\end{array}$} & \multicolumn{3}{|c|}{ Construction Costs $\left(\$ / \mathrm{ft}^{3}{ }^{3}\right)$} \\
\hline & $\begin{array}{l}\text { Low } \\
\$ 0.05\end{array}$ & $\begin{array}{l}\text { Average } \\
\$ 0.50\end{array}$ & $\begin{array}{l}\text { High } \\
\$ 3.20\end{array}$ \\
\hline 10,000 & $\$ 500$ & $\$ 5,000$ & $\$ 32,000$ \\
\hline $100,000^{\mathrm{a}}$ & $\$ 5,000$ & $\$ 50,000$ & $\$ 320,000$ \\
\hline $1,000,000$ & $\$ 50,000$ & $\$ 500,000$ & $\$ 3,200,000$ \\
\hline
\end{tabular}

${ }^{\text {a }}$ A 100,000 cubic-foot extended detention dry pond would contain the runoff from approximately 50 acres. Table adapted from Griffin, 1993, p. 65.

Operability. ED dry basins should be mown, and litter and debris removed, at least twice a year. Schueler, Heraty, and Kumble report that annual inspections should occur to unclog the control device (Griffin, 1993). Regrading and revegetation may be necessary. Sediment should be removed every five to ten years. Level of satisfaction: adequate.

Buildability. Space requirements are high. Schueler reports that ED dry ponds normally require 5\% of total site area (Griffin, 1993). The Washington Department of Ecology reports that steep slopes and proximity to buildings generally do not restrict site selection (Griffin, 1993). However, the water table should be two feet lower than the bottom of the pond. Soils should be relatively impermeable. Level of satisfaction: marginal. 
Environmental Effects. ED dry ponds do not cause problems of elevated temperatures or oxygen depletion downstream. If properly maintained, valuable meadow and wetland habitat can be created. Can create mosquito breeding and odor problems if not properly maintained. May encourage accumulation of trash: adequately satisfied.

Public acceptance. The public generally prefers wet ponds to dry ponds. Due to mosquitoes, trash accumulation and/or plant growth, ED dry ponds can become a nuisance if proper maintenance does not occur. Level of satisfaction: marginal.

Institutional Factors. The DPW should either maintain or inspect to ensure proper maintenance occurs. The DPW has experience designing, constructing, and maintaining dry ponds. Level of satisfaction: full.

\section{Infiltration Basins and Trenches}

These devices allow water to percolate through soils, where filtration and biological reactions remove pollutants. An infiltration basin is an impoundment where incoming stormwater runoff is stored until it gradually exfiltrates through the soil of the basin floor. An infiltration trench is a shallow, excavated trench that is backfilled with stone to create an underground reservoir.

Meets Program Goals. When working properly, infiltration basins have achieved removal rates of $60 \%$ for bacteria, 45 to $100 \%$ for sediment, and 45 to 100\% for nitrogen (Kedzierski, et al., 1994; USA EPA, 1993a). However, these BMP's have a high rate of failure (Galli, 1992). Level of satisfaction: adequate. 
Cost. Reported construction costs of infiltration basins range from $\$ 0.2$ to $\$ 1.2$ per cubic foot of storage. Reported construction costs of infiltration trenches range from $\$ 0.9$ to $\$ 9.2$ per cubic foot of storage (US EPA, 1993a). Studies by Ellington and Ferguson have used a model in which approximately 1,481 cubic feet of basin volume served one acre of drainage area. The above cost estimates indicate that construction of an infiltration basin with a ten-acre drainage area may cost from $\$ 2,962$ to $\$ 17,772$.

Annual maintenance costs for basins range form $\$ 0.03$ to $\$ 0.05$ per cubic foot. For trenches, they range from $\$ 0.3$ to $\$ 0.9$ per cubic foot (US EPA, 1993a). Level of satisfaction: adequate.

Operability. Infiltration BMP's in general have been recognized as "extremely fragile systems" with high rates of failure (Galli, 1992). Failures are often partially due to improper site selection, installation, or maintenance (Galli, 1992; US EPA, 1993a). Prince George's County, Maryland no longer permits the use of the present generation of infiltration basin systems (Galli, 1992). Problems with infiltration trench failures can be overcome with pre-treatment systems, such as sand filters or sump pits (Schueler, Kumble, and Heraty, 1992). Criterion not satisfied.

Buildability. The use of these BMP's require deep permeable soils. There should be four feet of separation between the bottom of the device and seasonal ground water levels (US EPA, 1993a). Infiltration basins require relatively large amounts of land; the space required for infiltration trenches is relatively small (US EPA, 1993a). Contributing drainage area for a basin may be from 2 to 15 acres; 
drainage area for a trench should not exceed five acres (Schueler, Kumble, and Heraty, 1992): Level of satisfaction: marginal.

Environmental Effects. These systems may cause contamination of ground water. Level of satisfaction: adequate.

Public Acceptance. Infiltration basins may be regarded as unattractive by neighbors. Levels of satisfaction: marginal for basins; adequate for trenches.

Institutional Factors. The DPW does not have experience using these BMP's. Level of satisfaction: marginal.

\section{Sand and Peat Filters}

There are numerous variations of sand and peat filters. They generally consist of a sediment chamber, into which the first flush is diverted. This allows coarse sediments to settle and velocity to be reduced before runoff spreads over a bed of sand or peat. The runoff filters through the medium, which traps or filters out pollutants. It is then collected by an underground pipe network, and released to a receiving water body. Underground-vault sand filter systems have been used in the Washington, DC area. This allows the sand filter to be placed under streets or parking areas.

Meets Program Goals. Pollutant removal rates of sand filters have been documented at 20 to $70 \%$ for fecal coliform, 75 to $85 \%$ for sediments, and 30 to $70 \%$ for nitrogen (Schueler, 1994b; Kedzierski, et al., 1994). Pollutant removal rates have been improved by combining a filter with an extended detention pond (Schueler, 
1994b). Level of criterion satisfaction: adequate.

Cost. Construction costs for sand filters have ranged from $\$ 10,000$ to $\$ 20,000$ per impervious acre treated (NVSWCD, 1994; Schueler, 1994b). Little is known about maintenance costs (Schueler, 1994b). Criterion is marginally satisfied.

Operability. Regular maintenance is essential to prevent clogging. Routine maintenance requirements include: surface sediment removal, raking, and removal of trash, debris, and leaf litter. The surface sand layer should also be replaced with relative frequency (Kedzierski et al., 1994). Sand filters have been used extensively in Austin, Texas, and in the metropolitan Washington D.C. area. Their capacity to withstand prolonged periods of freezing and thawing has not been tested. Level of satisfaction: marginal.

Buildability. These BMP's require relatively small amounts of space, and performance is unrelated to on-site soil capabilities. Different variations have been effective for drainage areas of 5 to 50 acres. They are recommended only for sites that are entirely impervious (Schueler, 1994b). Level of satisfaction: full.

Environmental Effects. Little is known about the environmental effects of these BMP's (Schueler, 1994b).

Public Acceptance. Filter BMP's tend to be unobtrusive. Level of satisfaction: adequate.

Institutional Factors. The DPW does not have experience with these BMP's. Level of satisfaction: marginal. 
Structural BMP Systems

Research has shown that effectiveness of individual structural BMP's can often be maximized by incorporating them into a system of structural BMP's. In addition to site-planning considerations, runoff impacts can be mitigated by using structural controls to accomplish different objectives. While wet ponds, constructed stormwater wetlands, and ED ponds have proven most effective in treating pollutants, other structural BMP's may be used for: conveyance, pre-treatment, and secondary impact mitigation (Schueler et al., 1991).

BMP's, such as grassed swales may be used to convey runoff to treatment or pre-treatment BMP's. Swales allow for some filtering and infiltration prior to treatment. Pre-treatment BMP's may include: infiltration trenches, sand filters, peat filters, vegetated filter strips, water-quality inlets, and oil-grit separators. Thorough explanations of these BMP's can be found in Schueler, Kumble, and Heraty, 1992; and RIDEM and RI CRMC, 1993.

Meets Program Goals. While some of the above-listed BMP's have not shown consistent moderate to high treatment of the pollutants of concern, their inclusion could enhance the effectiveness of other treatment facilities. Level of criterion satisfaction: adequate.

Cost. Estimated maintenance and construction costs for BMP's not previous listed are provided in Table 4.2. Because additional stages of BMP treatment increase costs, level of satisfaction is marginal. 
Table 4.2. Estimated Costs for Conveyance and Pre-treatment BMP's

\begin{tabular}{llll}
\hline BMP & $\begin{array}{l}\text { Measurement } \\
\text { Unit }\end{array}$ & Construction & $\begin{array}{l}\text { Annual } \\
\text { Maintenance }\end{array}$ \\
\hline $\begin{array}{l}\text { Grassed swales } \\
\text { Vegetated filter }\end{array}$ & $\begin{array}{l}1 \text { linear foot } \\
\text { strips }\end{array}$ & $\$ 4.5-8.5$ & $\$ 0.5-1.0$ \\
Water-quality inlets & 1 inlet & $\$ 0-\$ 48,000$ & $\$ 100-\$ 1,400$ \\
Oil-grit separators & 1 drainage acre & $\$ 15,000-20,000$ & $\$ 1,000$ \\
\hline
\end{tabular}
Source: US EPA, 1993a.

Operability. Water-quality inlets and oil-grit separators have high failure rates (Galli, 1992). Grassed swales should be mown two to three times per year (Coffman, 1994). Sediment should be removed periodically from each of these BMP's. Overall, the operability criterion for BMP systems is adequately satisfied.

Buildability. Water-quality inlets and oil-grit separators do not require surface land area, but they do require relatively permeable soils and low water tables. Grassed swales require small amounts of space, and space requirements of vegetated buffer strips vary. Soil capabilities and depths to ground water generally do not limit use of swales and vegetated filter strips. Overall, satisfaction level for this criterion is adequate.

Other Factors. Since these practices will most likely be used to support BMP's discussed earlier, environmental effects, public acceptance, and institutional factors will not be addressed separately. These factors are not rated. 


\section{Conclusion}

Following a discussion of BMP-selection strategies, this chapter identified BMP's that met two screening criteria: 1) effectiveness in mitigating pollutants of concern, and 2) appropriateness of implementation by the Warwick DPW. The BMP's that met the screening criteria have been organized according to the stage of the development process in which they are normally implemented. Advantages and disadvantages of each BMP were identified within the context of seven selection criteria: 1) meets program goals, 2) cost, 3) operability, 4) buildability, 5) environmental effects, 6) public acceptance, and 7) institutional factors. The following chapter will use this information to assess potential organizational and financial needs that would result from the implementation of proposed BMP's. 


\section{Chapter Five Assessment of Potential Organizational and Financial Needs}

As stated in Chapter Four, it is not within the scope of this study to conclusively identify the most appropriate BMP's for the study area. Rather, this chapter will outline a preliminary set of BMP's for the study area, which was developed using the selection criteria described in Chapter Four. This will provide the basis for assessing the organizational and financial needs likely to arise if the City of Warwick incorporates water quality goals into the stormwater management program.

This chapter is organized into three parts. First, the approach used in ranking and selecting BMP's will be explained. In the second part, the selected BMP's will be listed and evaluated. The list is divided into four categories: watershed planning, pre-development designand construction, post-development maintenance/restoration, and structural BMP's. The first three categories are based on phases of the development process. The use of structural BMP's is considered in each of the three phases of the development process. The fourth category compares structural BMP's. This comparison will be used to set parameters for activities selected for the three phases.

Within each of the four categories, an explanation of the selection process will be given. For each selected BMP, assumed parameters will be explained. Assessments of organizational and/or financial needs will be based on the assumed parameters. In general, cost estimates for each item will be based on the assumption 
that the item is implemented in 1995. To the greatest extent possible, estimates will be made of approximate cost for the first full calendar year of implementation (1996) and for the fifth full calendar year of implementation (2000). Estimates of future costs will not be adjusted for inflation.

The third and final part of this chapter will assess the organizational and financial impacts of the selected alternatives. An inventory of organizational needs will be made. This will be followed by a rough estimate of the total cost of implementing all selected BMP's.

\section{Selection of Alternatives}

It is assumed that at least one alternative should be selected for each of the three phases of development identified above, in order to avoid leaving gaps in the overall effectiveness of pollution mitigation. For each of the four categories of BMP's, a matrix was created to compare the ratings assigned in Chapter Four. Each BMP received a rating for its level of satisfaction of selection criteria. Levels of satisfaction were rated as: full, adequate, marginal, or does not satisfy.

Although the satisfaction ratings serve as guide, selection of BMP's was based on qualitative evaluation of these attributes, as they were described in Chapter Four. In general, alternatives that predominantly provide full satisfaction of criteria were selected, and those with more than one "does not satisfy" rating were not selected. Greatest weight was placed on the criterion of meeting program goals. Cost and institutional considerations were, respectively, the second and third most important 
criteria. Knowledgeable professionals in stormwater management, planning, and watershed protection were consulted to confirm the appropriateness of these selections.

The option of using a quantitative analysis to evaluate BMP's was considered. However, numerical ratings of satisfaction levels did not seem to increase the accuracy of the analysis. Rather, it seemed to mask the uncertainty and subjectivity of this analysis with false appearance of accuracy. Since this is a preliminary list of BMP's for planning purposes, a qualitative evaluation provides sufficient analytical rigor.

\section{Stormwater Planning Activities}

Using information presented in Chapter Four, attributes of four stormwater planning activities were compared, as presented in Table 5.1. Based on a review of these BMP's, two were selected for implementation: the stormwater master plan and the capital improvement program and budget.

Table 5.1. Comparison of Stormwater Management Planning Activities

\begin{tabular}{lccccccc} 
Activity & $\mathbf{1}$ & $\mathbf{2}$ & $\mathbf{3}$ & $\mathbf{4}$ & $\mathbf{5}$ & $\mathbf{6}$ & $\mathbf{7}$ \\
\hline SW Master Plan & F & M & -- & -- & A & A & A \\
CIPB & F & F & F & -- & A & F & A \\
Inter-juris. & A & F & M & -- & -- & A & M \\
cooperation & & & & & & & \\
GIS & F & M & M & -- & - & A & N \\
\hline
\end{tabular}

Key: $\quad 1=$ Meets program goals; $2=\operatorname{Cost;} 3=$ Operability, $4=$ Buildability; $5=$ Environmental effects; $6=$ Public acceptance; 7 = Institutional considerations.

$F=$ Fully satisfies criterion; $A=$ Adequately satisfies; $M=$ Marginally satisfies; $N=$ Does not satisfy; - indicates no information. 
Stormwater Management Master Plan

Reasons for Selection. This alternative was selected largely because of its strength in meeting program goals and recent demonstrations of institutional commitment to managing stormwater.

Assumed Parameters. It will be assumed that a stormwater management plan for the Greenwich Bay watershed will be developed by a consultant. This plan will include: inventories of the natural and man-made drainage systems, identification of appropriate improvements for each sub-basin of the watershed, prioritization of these improvements, a schedule of costs, and a time-table for improvements.

Organizational Needs. The DPW would need to write a request for proposals and select a consulting firm to accomplish this work. A project manager should be selected from within the department to oversee the firm's work, and facilitate its access to necessary information.

Financial Needs. Review of stormwater management literature and consultation with professional planners indicated that $\$ 200,000$ would be a reasonable estimate for the cost of developing a stormwater master plan. It should be noted that costs borne by Warwick could be substantially decreased if the municipalities in the Greenwich Bay watershed jointly financed a watershed-wide stormwater master plan. Potential costs of recommendations that may be made by a stormwater master plan will be estimated in the section on restoration and maintenance activities. 
Capital Improvement Program and Budget (CIPB)

Reasons for Selection. This alternative received more favorable ratings than any other in the Stormwater Planning Activities section. This was due to its clear advancement of program goals, and the ease with which it may be implemented.

Assumed Parameters. It is assumed that the Director of the DPW, in consultation with his staff, will include a water-quality criterion in the criteria for selecting capital improvements projects. The purpose of developing a new criterion would be to protect or enhance water quality in Greenwich Bay or other environmentally-sensitive water body. For projects in the Greenwich Bay watershed, attention should be directed specifically at mitigating bacterial contamination, sediment, and nitrogen. This criterion would not be weighted more highly than matters of public safety.

Organizational Needs. A review should be made of the restrictions on the use of funds currently allocated to drainage facilities by the city's Capital Improvement Program and Budget. The only other major organizational requirements are the Director's formulation of a new criterion, and decision regarding the relative weight of that criterion.

Financial Needs. No outlay of funds would be required to implement this activity. Capital funds have already allocated to stormwater management improvements. 
Alternatives Not Selected

Regional / inter-jurisdictional stormwater management and the implementation of a geographical information system were not selected. Nonselection of inter-jurisdictional cooperation was based primarily on uncertainty of neighboring communities' commitment to addressing nonpoint source pollution problems in Greenwich Bay. Inter-jurisdictional cooperation does, however, show promise for cost-saving and improving effectiveness of watershed protection activities. It is suggested that Warwick attempt to involve the other watershed communities in specific activities the city wishes to undertake.

Despite its strength in advancing program goals, the GIS alternative was not selected because it appears that the Department of Planning is leading that initiative. As the DOP's research of GIS options progresses, the DPW would be well advised to identify ways in which city departments may share this technology.

\section{Pre-development and Construction Activities}

Information presented in Chapter Four was used to compare attributes of four pre-development and construction activities. This comparison is presented in Table 5.2. Three alternatives were selected for implementation: design criteria, building permit reviews, and construction inspections.

\section{Design Criteria}

Reasons for Selection. This alternative was selected because of its strength in 
Table 5.2. Comparison of Pre-Development and Construction Activities

\begin{tabular}{|c|c|c|c|c|c|c|c|}
\hline Activity & 1 & 2 & 3 & 4 & 5 & 6 & 7 \\
\hline Design Criteria & $F$ & $\mathrm{~F}$ & F & -- & -- & M & A \\
\hline $\begin{array}{l}\text { Bldg. Pmt. } \\
\text { Reviews }\end{array}$ & $\mathrm{F}$ & A & -- & -- & -- & M & A \\
\hline $\begin{array}{l}\text { Dvlpt. Plan } \\
\text { Reviews }\end{array}$ & $\mathbf{F}$ & $\mathbf{M}$ & -- & -- & -- & M & $\mathrm{N}$ \\
\hline $\begin{array}{l}\text { Construction } \\
\text { Inspections }\end{array}$ & $\mathrm{F}$ & A & -- & -- & -- & M & A \\
\hline
\end{tabular}

Key: $\quad 1=$ Meets program goals; $2=$ Cost; $3=$ Operability; $4=$ Buildability; $5=$ Environmental effects; $6=$ Public acceptance; 7 = Institutional considerations.

$F=$ Fully satisfies criterion; $A=$ Adequately satisfies; $M=$ Marginally satisfies; $N=$ Does not satisfy, - indicates no information.

meeting program goals and its low cost. The simplicity of adopting standards outlined in the state stormwater manual standards was also in its favor.

Assumed Parameters. It will be assumed that Warwick adopts standards from the State Stormwater Manual for the Greenwich Bay watershed, using Section 312 (Watershed Protection Overlay District) of the Zoning Ordinance.

If the DOP determines it is not feasible to amend the Zoning Ordinance, the Subdivision Regulations may be used to provide the Director of Public Works with authority to require or recommend practices outlined by the State Stormwater Manual for sensitive areas.

Organizational Needs. The Department of Planning will need to write Section 312 for amendment of the Zoning Ordinance, and the amendment must be ratified by the City Council. If the ordinance is not amended, legal advice should be obtained as to whether the DPW Director should require or recommend BMP's in 
environmentally-sensitive areas. Training may be required to better acquaint engineering staff with water quality considerations for stormwater reviews.

Financial Needs. The DPW already reviews all subdivision plans, and some site plans for building permit applications. Incorporating new stormwater design standards into these reviews should not require a significant amount of extra staff time. It may be possible to arrange for training in the use of the state stormwater design standards at low cost or no cost, from NRCS, RIDEM, or RI CRMC.

\section{Building Permit Review}

Reasons for Selection. This alternative was selected because of its clear advancement of program goals, its low cost, and its relative ease of implementation.

Assumed Parameters. It is assumed that the building official, in consultation with the DPW and DOP, would identify specific attributes of developments for which stormwater plans should be reviewed. For the purposes of this study, it is assumed the following attributes will trigger a stormwater review: commercial or multi-unit residential developments with one acre or more of parking facilities, roadways, or impervious surfaces.

Based on personnel cost and time estimates made in Chapter Four, it will be assumed that each review requires one hour, at a cost of $\$ 18$. Cost estimates will be made for 1996, hypothetically the first full calendar year the new policy would be in effect. It is assumed that the approximate number of building permit applications in 1996 will be similar to the last few years. 
The number of stormwater reviews expected to result from this formalized standard can be determined by obtaining estimates of: 1) the annual number of building permit applications that currently receive stormwater reviews, and 2) the annual number of building permit applications that meet proposed, formalized criteria. According to DPW staff, the number of building applications that have received stormwater reviews over the past several years has ranged from 5 to 12 per year. According to DOP staff, about $5 \%$ of building permit applications have met the proposed criteria over the past several years. Numbers of building permits issued for new construction per year were reviewed for 1991 through 1994. Calculating 5\% of the totals for these years resulted in a range of 5 to 9 . It seems most likely that the formalization of review criteria would result in an increase of no less than 0 and no more than 4 reviews annually.

Organizational Needs. The Building Official may wish to consult with the Directors of the DOP and DPW (or designees) to identify review thresholds.

Financial Needs. There would be no additional cost if the formalization of criteria results in zero additional reviews. If it results in four, this would be at a cost of $\$ 72$ per year. If it is assumed that this alternative results in an average of two additional reviews per year, the cost each year is $\$ 36$.

\section{Construction Inspections}

Reasons for Selection. This activity was selected because of its strength in advancing program goals, and the relative ease with which it could be implemented. 
Assumed Parameters. The implementation of this BMP would result in the presence of stormwater management inspectors at construction sites during critical stages of construction. For the purposes of calculating costs, it is assumed that for every inspection of a site where a BMP is being constructed, an additional inspection would be required to witness a critical stage in construction. Based on personnel cost and time estimates made in Chapter Four, each inspection is assumed to cost $\$ 48$ in staff time.

Inspections are conducted for construction of subdivisions and physical alterations. According to DOP staff, approximately 10 subdivision applications are approved each year. According to DPW staff approximately 200 applications for physical alterations are approved each year. Thus, it can be estimated that the DPW conducts approximately 210 construction inspections per year. However, the vast majority of these inspections do not involve structural BMP's. In order to estimate potential costs of additional construction inspections, it will be assumed that under new regulations, half of the subdivisions will be require to build structural BMP's. Thus, additional inspections would occur for five projects per year.

Cost estimates will be made for 1996, hypothetically the first full year the new policy is in effect. It is assumed that the approximate number of subdivision applications approved in 1996 will be similar to the last few years.

Organizational Needs. Protocols for inspections at critical stages would need to be developed. Arrangements with developers would need to be made so that the DPW would be notified in advance of construction activities that require inspections. 
Assumed Parameters. The implementation of this BMP would result in the presence of stormwater management inspectors at construction sites during critical stages of construction. For the purposes of calculating costs, it is assumed that for every inspection of a site where a BMP is being constructed, an additional inspection would be required to witness a critical stage in construction. Based on personnel cost and time estimates made in Chapter Four, each inspection is assumed to cost $\$ 48$ in staff time.

Inspections are conducted for construction of subdivisions and physical alterations. According to DOP staff, approximately 10 subdivision applications are approved each year. According to DPW staff approximately 200 applications for physical alterations are approved each year. Thus, it can be estimated that the DPW conducts approximately 210 construction inspections occur per year. However, the vast majority of these inspections do not involve structural BMP's. In order to estimate potential costs of additional construction inspections, it will be assumed that under new regulations, half of the subdivisions will be require to build structural BMP's. Thus, additional inspections would occur for five projects per year.

Cost estimates will be made for 1996, hypothetically the first full year the new policy is in effect. It is assumed that the approximate number of subdivision applications approved in 1996 will be similar to the last few years.

Organizational Needs. Protocols for inspections at critical stages would need to be developed. Arrangements with developers would need to be made so that the DPW would be notified in advance of construction activities that require inspections. 
Training of staff may be necessary to ensure inspections are conducted appropriately.

Financial Needs. Based on assumed parameters, an additional 5 inspections would be necessitated by this new policy. This would result in an estimated additional cost of $\$ 240$. If the approximate annual number of new subdivisions is similar for the ensuing five years, the estimated increased costs for construction inspections would be $\$ 240$ each year.

Alternative Not Selected

The development plan review alternative was not selected. This is due primarily to the fact that this alternative would have the greatest impact on the Department of Planning. Thus, it is outside the scope of this study which is examining potential impacts on the existing stormwater management program, which is a responsibility of the DPW.

\section{Resource Maintenance and/ or Restoration}

Information presented in Chapter Four was used to compare attributes of seven maintenance and/or restoration activities for developed areas. This comparison is presented in Table 5.3. Four alternatives were selected for implementation: maintenance inspections, increased maintenance activities for the public stormwater system, construction of new structural BMP's, and retrofitting of existing stormwater management facilities with BMP structure. 
Table 5.3. Comparison of Maintenance and Restoration Activities

\begin{tabular}{|c|c|c|c|c|c|c|c|}
\hline Activity & 1 & 2 & 3 & 4 & 5 & 6 & 7 \\
\hline $\begin{array}{l}\text { Maintenance } \\
\text { Inspections }\end{array}$ & F & A & -- & -- & - & M & A \\
\hline $\begin{array}{l}\text { Increased Public } \\
\text { SWM } \\
\text { Maintenance }\end{array}$ & F & A & -- & -- & - & A & A \\
\hline $\begin{array}{l}\text { SW Quality } \\
\text { Monitoring }\end{array}$ & $\mathrm{F}$ & M & -- & -- & -- & A & M \\
\hline Street Sweeping & A & M & -- & -- & A & A & M \\
\hline $\begin{array}{l}\text { I.D. Cross- } \\
\text { Connectns. }\end{array}$ & A & $\mathrm{N}$ & A & -- & -- & -- & M \\
\hline $\begin{array}{l}\text { New Struct'l } \\
\text { BMP's }\end{array}$ & $\mathrm{F}$ & M & -- & M & -- & A & $\mathrm{F}$ \\
\hline $\begin{array}{l}\text { Retrofit SWM } \\
\text { facilities }\end{array}$ & $F$ & A & -- & M & -- & A & $\mathrm{F}$ \\
\hline
\end{tabular}

Key: $\quad 1=$ Meets program goals; $2=$ Cost; $3=$ Operability; $4=$ Buildability; $5=$ Environmental effects; $6=$ Public acceptance; 7 = Institutional considerations.

$\mathrm{F}=$ Fully satisfies criterion; $\mathrm{A}=$ Adequately satisfies; $\mathrm{M}=$ Marginally satisfies; $N=$ Does not satisfy; - indicates no information.

\section{Maintenance Inspections}

Reasons for Selection. This BMP was selected primarily because strong emphasis has been placed on the need to ensure maintenance of private facilities by numerous practitioners and researchers in stormwater management. Inspecting private facilities is significantly less costly than assuming financial responsibility for them (Hawley and McCuen, 1987).

Assumed Parameters. It is assumed that maintenance inspections would occur annually, and that each inspection may require as much as one-third of a day of staff time, or as little as one hour. Based on personnel cost and time estimates made in 
Chapter Four, a one-third-day inspection would cost $\$ 48$ in staff time and a one-hour inspection would cost $\$ 18$.

It is further assumed that inspections would be made of structural BMP's constructed in the study area after regulations have been made authorizing inspections, and according to maintenance plans approved by the DPW. Authority to inspect for maintenance would not include BMP's already constructed or under construction when the regulations go into effect. It is assumed that 8 new individual developments and 5 new subdivisions that require BMP's are constructed each year. Under proposed new design criteria, these would require the preparation of a stormwater management maintenance plan. Structural BMP's in the subdivisions will dedicated to the city, unless the subdivision consisted of condominiums or apartment buildings. It will be estimated that one of the subdivisions requiring BMP's would not dedicate its BMP's to the city. Thus, in the first year after passage of the new regulations, an estimated 9 inspections would be necessary.

Organizational Needs. Legal authority to inspect and enforce maintenance requirements would have to be established. Protocols for inspections and enforcement would have to be developed. Staff should be trained. Staffing needs would increase as more developments are built. To increase public acceptance of these inspections, it may be advisable to develop a public awareness program.

Financial Needs. Conducting nine inspections in the first year would cost an estimated $\$ 432$, if 3 sites are inspected per day. If 8 sites are inspected in one day (one hour for each inspection), then the cost would be $\$ 162$. If nine more 
developments are built in each of the following four years, the high estimate of the cost of maintenance inspections in the fifth year would be $\$ 2,160$. The low estimate for that year would be $\$ 810$. The high estimate would require approximately 120 person-hours, or a total of 15 workdays. The low estimate would require approximately 45 person-hours, or approximately 5.5 workdays.

\section{Additional Public SWM Maintenance}

Reasons for Selection. This action was selected due to the clear connection between proper maintenance and meeting pollution-reduction goals.

Assumed Parameters. Chapter Three established that the existing maintenance program does not include certain activities that help mitigate water quality problems. It is assumed that the DPW would add the following items: vegetation control in and around detention basins, and removal of sedimentation from detention basins. It is also assumed that frequency of three activities will be increased: underground cleaning of detention basins, clearing of vegetation from natural channels, and cleaning and removal of sedimentation from natural channels. At present these three activities are not performed routinely.

As structural BMP's are incorporated into the public stormwater management system, and BMP's in residential developments are dedicated to the city, the need for maintenance will increase. Additional costs that result from public construction of new BMP's and BMP retrofits of existing stormwater facilities will be estimated 
in the "Constructing New BMP's" and "Retrofitting Stormwater Management Facilities" sub-sections.

Organizational Needs. Routines and schedules would have to be developed. Staffing requirements will increase as the number of structures to maintain increases. Raising public awareness of maintenance needs of stormwater management facilities may prevent objections to the cost of maintenance.

Financial Needs. Per-unit person hours and costs of equipment/ materials are based on estimates made by Pyzoha (1994) and Washington County, Oregon (no date). Where sources disagree regarding hours or cost, the lower number was used. Based on knowledge of the study area, it was estimated that the city is currently responsible for 10 detention basins and 10,000 linear feet of open channels. It is assumed that the amount of open channels will remain constant, and that the city will accept two additional residential detention basins for maintenance each year. This would result in a total of 12 detention basins requiring public maintenance in 1996 and a total of 20 in the year 2000.

Estimates of potential costs of additional maintenance activities in 1996 are presented in Table 5.4. Using the same assumptions for person-hours and costs of equipment/ materials assumptions, it is estimated that the cost of these public maintenance activities will be $\$ 22,484$ in 2000 . This does not include the increased costs of activities the city already performs. 
Table 5.4. Potential Cost of Additional Maintenance Activities in the Study Area in 1996

\begin{tabular}{|c|c|c|c|c|c|c|}
\hline \multirow[t]{2}{*}{ Maint. Activity } & \multirow[t]{2}{*}{ Unit } & \multicolumn{2}{|c|}{ Per Unit } & \multirow{2}{*}{$\begin{array}{l}\text { Total } \\
\text { units }\end{array}$} & \multirow{2}{*}{$\begin{array}{l}\text { Annual } \\
\text { Proq'y }\end{array}$} & \multirow{2}{*}{$\begin{array}{l}\text { Total Annual } \\
\text { Cost }\end{array}$} \\
\hline & & $\begin{array}{l}\text { Person } \\
\text { days } 1\end{array}$ & $\begin{array}{l}\text { Equip/Mat } \\
\text { Costs }\end{array}$ & & & \\
\hline Det'n basin- veg'n control & 1 basin & 1.50 & $\$ 187.00$ & 12 & 1.50 & $\$ 6,174$ \\
\hline $\begin{array}{l}\text { Det'n basin- remove } \\
\text { sediment }\end{array}$ & 1 basin & 5.00 & $\$ 464.00$ & 12 & 0.20 & $\$ 2,362$ \\
\hline $\begin{array}{l}\text { Det'n basin- underground } \\
\text { cleaning }\end{array}$ & 1 basin & 0.67 & $\$ 196.00$ & 12 & 0.50 & $\$ 1,594$ \\
\hline $\begin{array}{l}\text { Natural channels-veg'n } \\
\text { clearing }\end{array}$ & 1,000 I.ft. & 1.50 & $\$ 0.10$ & 10 & 3.00 & $\$ 4,683$ \\
\hline $\begin{array}{l}\text { Natural channels-remove } \\
\text { sediment }\end{array}$ & 1,000 l.ft. & 2.67 & $\$ 0.40$ & 10 & 0.33 & $\$ 918$ \\
\hline TOTAL & & & & & & $\$ 15,731$ \\
\hline
\end{tabular}

1 Each person day estimated to cost $\$ 104$, based on calculations in Chapter Four.

Sources: Pyzoha, 1994; Washington County, Oregon, no date.

\section{Constructing New Structural BMP's}

Reasons for Selection. This action was selected due to the amount of urbanized land in the area. Requiring structural BMP's in new development will not substantially reduce existing pollution problems.

Assumed Parameters. Without extensive studies of site-specific problems, it is difficult to make any meaningful estimates of how many new structural BMP's might be warranted in the study area. For the sake of establishing a gross estimate of potential needs, it will be assumed that structural BMP's effective in treating the pollutants of concern will be the highly developed portion of the study area. For the purposes of this study, "highly developed areas" will include the land uses listed in Table 5.5. 
Table 5.5. Approximation of Amount of Highly-Developed Land in Study Area

\begin{tabular}{|c|c|c|c|}
\hline $\begin{array}{l}\text { Highty-dvlpd. Land Uses: Warwick (+ part of } \mathrm{E} \text {. } \\
\text { Greenwich) }\end{array}$ & Sq. Miles & Acres & $\%$ of Study Area \\
\hline High Density Residential ( $<1 / 8$ acre lots) & 0.776 & 496.985 & 4.3 \\
\hline Medium High Density Res. (1/8-1/4 acre lots) & 4.782 & 3060.184 & 26.2 \\
\hline Commercial & 1.145 & 732.552 & 6.3 \\
\hline Industrial & 0.101 & 64.480 & 0.6 \\
\hline Roads & 0.616 & 393.953 & 3.4 \\
\hline Airports & 0.233 & 149.026 & 1.3 \\
\hline Water and Sewage Treatment & 0.017 & 10.765 & 0.1 \\
\hline Waste Disposal & 0.009 & 5.603 & 0.1 \\
\hline Other Transportation & 0.026 & 16.477 & 0.1 \\
\hline Commercial/Industrial Mix & 0.087 & 55.567 & 0.5 \\
\hline Institutional & 0.426 & 272.600 & 2.3 \\
\hline Mines, Gravel Pits & 0.113 & 72.252 & 0.6 \\
\hline TOTALS & 8.331 & $5,330.444$ & 45.6 \\
\hline
\end{tabular}

1 It was not technically feasible to fully separate community land use data.

Source: RIGIS database, last updated in 1988.

The total amount of highly-developed land in the study area is approximately 5,330 acres. It should be recognized that this is not an accurate inventory of highlydeveloped land in the study area. There are two major sources of inaccuracy. First, some East Greenwich data is included, which tends to cause reported amount of area to be greater than actual amount. Secondly, development has occurred in this area since the land use data was collected seven years ago. This tends to cause the reported amount of area to be less than the actual amount. However, this is the best data set available for the study area. Therefore it will be used, but only for general estimation purposes.

The number of BMP's potentially required will be based upon an estimate of 
the amount of impervious acreage in the highly-developed portion of the study area. Using estimated percentages listed in Table 5.6, the total amount of impervious surfaces in the highly-developed areas is estimated as 2,992 acres.

Table 5.6. Estimated Impervious Area for Highly-Developed Land in Study Area

\begin{tabular}{|c|c|c|c|}
\hline $\begin{array}{l}\text { Highly-dvipd. Land Uses: Warwick (+ part of } \mathrm{E} \\
\text { Greenwich) }\end{array}$ & Acres & Perct Imperv ${ }^{2}$ & $\begin{array}{l}\text { Imperv. } \\
\text { Acres }\end{array}$ \\
\hline High Density Residential ( $<1 / 8$ acre lots) & 496.985 & 65 & 323.0 \\
\hline Medium High Density Res. (1/8-1/4 acre lots) & 3060.184 & 40 & $1,224.1$ \\
\hline Commercial & 732.552 & 85 & 622.7 \\
\hline Industrial & 64.480 & 72 & 46.4 \\
\hline Roads & 393.953 & 98 & 386.1 \\
\hline Airports & 149.026 & 85 & 126.7 \\
\hline Water and Sewage Treatment & 10.765 & 72 & 7.8 \\
\hline Waste Disposal & 5.603 & 72 & 4.0 \\
\hline Other Transportation & 16.477 & 98 & 16.1 \\
\hline Commercial/Industrial Mix & 55.567 & 78 & 43.3 \\
\hline Institutional & 272.600 & 50 & 136.3 \\
\hline Mines, Gravel Pits & 72.252 & 72 & 52.0 \\
\hline TOTALS & $5,330.444$ & & 2,9915 \\
\hline
\end{tabular}

\footnotetext{
1 It was not technically feasible to fully separate community land use data.

2 Percentages are based on U.S. Soil Conservation Service estimates reported by Wanielista (1979).

3 Impervious acreage of highly-developed land is estimated based on percentage assumptions.
}

Sources: $\quad$ RIGIS database, last updated in 1988; Wanielista, 1979.

It will be assumed that one-half of the highly developed area (1,496 acres) will contain newly-constructed BMP's and the other half retrofits. This will enable cost estimates to take into consideration the differences in cost between these two categories. It will be further assumed that the structural BMP's will be implemented in the highly-developed area as follows: wet ponds will be used for $35 \%$ of this area (524 acres), extended detention dry ponds for 55\% ( 823 acres), and stormwater 
wetlands for $10 \%$ ( 150 acres). The reasons for selecting these percentages of these BMP's are explained in the "Structural Best Management Practices" section of this chapter. The cost of constructing these BMP's to serve the respective areas will be based on average costs of BMP's reported in Chapter Four.

Organizational Needs. The construction of new BMP's would need to be scheduled over a period of years. A stormwater management master plan would provide guidance for this task. Public awareness initiatives should be considered to help increase public acceptance of this costly alternative.

Financial Needs. The assumptions made above would result in the construction of: ten 100,000-cubic-foot wet ponds at an average cost of $\$ 80,000$ each, sixteen 100,000-cubic-foot ED dry ponds at an average cost of $\$ 50,000$ each, and three 1.5-acre constructed stormwater wetlands at an average price of $\$ 97,500$ each. The total estimated cost of this installation of new BMP's in one-half of the study area is $\$ 1,892,500$.

Currently, $\$ 1$ million (which is $52.8 \%$ of $\$ 1,892,500$ ) has been ear-marked for construction or retrofit of structural BMP's. Based on cost estimates made above, $\$ 1$ million would be adequate to construct new BMP's to treat approximately $26 \%$ of the highly-developed portion of the study area. More information is needed about site-specific runoff problems to determine which portion of the study area would benefit most from structural BMP installation.

The $\$ 1$ million does not, however, cover the ongoing costs of maintaining structural BMP's. Using maintenance costs of structural BMP's listed in Chapter 
Four, the costs of maintaining each of category of the installed BMP's are estimated as $\$ 39,000$ for wet ponds ( $\$ 3,900$ per 100,000 cubic-foot wet pond), $\$ 32,000$ for ED dry ponds ( $\$ 2,000$ per 100,000 cubic-foot ED dry pond), and $\$ 60,000$ ( $\$ 400$ per acre of drainage area) for constructed stormwater wetlands. Thus, the total estimated amount for maintenance of newly constructed BMP's in one-half the study area is $\$ 131,000$. The cost of maintaining $\$ 1,000,000$ of newly constructed BMP's would be approximately $52.8 \%$ of this figure, or $\$ 69,168$.

Retrofitting Stormwater Management Facilities

Reasons for Selection. This alternative was selected essentially for the same reason the "new construction" alternative was selected. However, retrofitting is preferred, where feasible, since it tends to be considerably less costly than new construction.

Assumed Parameters. In the absence of on-site surveys it is impossible to know how many existing stormwater facilities in the study area could be effectively retrofitted. For the sake of making a general estimate, it will be assumed that onehalf of the developed portion of the study area will be treated by retrofitted BMP's. Costs will be estimated, using the same mix of BMP's used to estimate costs of new construction. Based on consultation with professional planners, it is assumed that retrofit costs will be one-half of the cost of new construction.

Organizational Needs. Retrofit sites should be identified and a construction schedule established. A stormwater management master plan would provide 
guidance for these tasks. Public awareness initiatives should be considered to increase public acceptance.

Financial Needs. The retrofitting of BMP's into existing drainage facilities for one-half the study area can be calculated as costing $\$ 946,250$. The $\$ 1$ million currently allocated for structural BMP's is approximately $105.6 \%$ of this figure). If the $\$ 1$ million were spent entirely on retrofits, it appears it would be adequate to treat water quality problems in about $52.8 \%$ of the highly-developed portions of the study area. As mentioned earlier, more research is required to identify the sites where BMP's could be most effectively used to address pollution problems. These sites may or may not be suitable for retrofitting existing drainage facilities.

The cost of maintaining retrofitted BMP's would not necessarily be any less than that of maintaining newly constructed BMP's. Thus, it is estimated that annual costs for maintenance of the retrofitted structures would cost be the same as estimates for newly-constructed BMP's for one-half of the highly-developed portion of the study area: $\$ 131,000$. The annual cost of maintaining $\$ 1$ million of retrofitted BMP's can be estimated as $105.6 \%$ of this figure, or $\$ 138,336$.

\section{BMP's Not Selected}

The following practices for maintaining or restoring water quality in developed areas were not selected: cross-connection identification and removal, stormwater quality monitoring, and street sweeping. The cross-connection option was not selected primarily because results from the on-going water quality studies sponsored 
by RIDEM and the city should provide better information about the relative need for further investigations. The street sweeping option was not selected, due to its relative ineffectiveness in reducing pollutants of concern, and its relatively steep funding and staffing requirements.

The stormwater quality monitoring option was not selected because, at this time, the stormwater program has neither the necessary equipment nor technicallytrained staff to conduct this activity. However, when the US EPA issues forthcoming NPDES stormwater regulations for communities with population under 50,000 , the stormwater management program may be required to monitor stormwater (US EPA, 1993c).

\section{Structural Best Management Practices}

Information presented in Chapter Four was used to compare attributes of seven structural BMP's. This comparison is presented in Table 5.7. Three alternatives were selected for use in the new construction and retrofitting scenarios explained above: wet ponds, constructed stormwater wetlands, and extended detention dry ponds.

\section{Wet Ponds}

Qualitative analysis of the information on structural BMP's presented in Chapter Four resulted in ranking wet ponds as the second-most preferred structural BMP for the study area. It out-performed most other BMP's in this category in 
Table 5.7. Comparison of Structural BMP's

\begin{tabular}{lccccccc}
\hline Activity & $\mathbf{1}$ & $\mathbf{2}$ & $\mathbf{3}$ & $\mathbf{4}$ & $\mathbf{5}$ & $\mathbf{6}$ & $\mathbf{7}$ \\
\hline Wet Ponds & F & M & A & M & M & A & A \\
Const. SW & F & N & M & M & M & M & N \\
Wetlands & & & & & & & \\
ED Dry Ponds & F & A & A & M & A & M & F \\
Infiltration & A & A & N & M & A & M & M \\
Basins & & & & & & & \\
Infiltration & A & A & N & M & A & A & M \\
Trenches & & & & & & & \\
Sand/Peat Filters & A & M & M & F & -- & A & M \\
BMP Systems & A & M & A & A & -- & -- & -- \\
\hline
\end{tabular}

Key: $\quad 1=$ Meets program goals; $2=$ Cost; $3=$ Operability, $4=$ Buildability; $5=$ Environmental effects; $6=$ Public acceptance; $7=$ Institutional considerations.

$F=$ Fully satisfies criterion; $A=$ Adequately satisfies; $M=$ Marginally satisfies; $N=$ Does not satisfy; - indicates no information.

meeting program goals, operability, cost, and public acceptance. However, it was surpassed by extended detention dry ponds in cost, environmental effects, and institutional factors. The percentage of wet ponds used for treatment of runoff of impervious areas in highly developed portions of the study area will be $35 \%$.

\section{Constructed Stormwater Wetlands}

This BMP ranked third in the qualitative analysis of structural BMP's. Although constructed stormwater wetlands performed well in meeting program goals, they were surpassed by both wet ponds and ED dry ponds in categories of cost, operability, and institutional factors. In spite of this BMP's failure to meet either the cost or institutional criteria, it is suggested that some wetlands be constructed on a 
trial basis for treatment of runoff in the study area. They will be used to treat $10 \%$ of the impervious area in highly-developed portions of the study area.

\section{Extended Detention Dry Ponds}

Of the structural BMP's qualitatively analyzed for this study, ED dry ponds were considered the overall best choice for the study area. This is due to their good performance in meeting program goals, cost, operability, environmental effects, and institutional factors. It will be assumed that this BMP is used for treatment of runoff in $55 \%$ of the impervious portion of highly-developed land in the study area.

\section{Structural BMP's Not Selected}

Although infiltration basins and trenches are relatively inexpensive and potentially effective in removing pollutants of concern, these BMP's were not selected due to their high rates of failure. If innovations in infiltration structures improve their operability, these BMP's would be appropriate for use in the study area. Sand and peat filters were not selected primarily due to costs of both construction and maintenance. They are, however, highly buildable in developed areas, such as the Greenwich Bay watershed and may be an option to consider in the future. BMP systems were not selected for use in the study area because they generally do not directly increase removal rates of bacterial contamination. Thus, the expense of constructing a BMP system, rather than a basic BMP may not be fully justified. 


\section{Potential Organizational Needs}

The implementation scenario described above will provide the basis for assessing the organizational needs likely to arise if water quality goals are incorporated in the stormwater management program. Table 5.8 inventories these potential needs. Since the Department of Public Works has responsibility for most activities related to stormwater management, the organizational needs in Table 5.8 consist primarily of actions that would be conducted by the DPW. Where actions should be conducted by other governmental units -- such as the Department of Building (DOB) or Department of Planning (DOP) -- those units are identified.

\section{Estimates of Potential Financial Needs}

The implementation scenario described in this chapter provides the basis for assessing the financial needs likely to arise if water quality goals are incorporated in Warwick's stormwater management program. Table 5.9 presents a rough estimate of the total cost of implementing all selected BMP's. Earlier sections of this chapter explain the assumed parameters of each item, on which each cost estimate has been made. 


\section{Table 5.8. Potential Organizational Needs Resultant from Establishing Stormwater Quality Goals}

\begin{tabular}{|c|c|c|}
\hline \# & Selected Alternatives & Organizational Needs \\
\hline 1 & Stormwater Master Plan & $\begin{array}{l}\text { Write a request for proposals \& select consultant. Assign project } \\
\text { manager. }\end{array}$ \\
\hline 2 & CIPB & Review restrictions on allocating CIPB funds. Formulate new criterion. \\
\hline 3 & Design Criteria & $\begin{array}{l}\text { DOP to write Sect. } 312 \text { of Zoning Ord. or Subdiv. Regs. City Council } \\
\text { to approve. Training in water quality issues may be helpful for review } \\
\text { staff. }\end{array}$ \\
\hline 4 & Building Permit Reviews & $\begin{array}{l}\text { Consultation among DOB, DOP, and DPW may be required to clarify } \\
\text { criteria for reviews. }\end{array}$ \\
\hline 5 & Construction Inspections & $\begin{array}{l}\text { Protocols to be developed. Arrangements to be made with developers } \\
\text { re: timing of inspections. }\end{array}$ \\
\hline 6 & Maintenance Inspections & $\begin{array}{l}\text { Establish legal authority (via Zoning Ord. or Subdiv. Regs.). Develop } \\
\text { protocols, train staff. Public awareness initiatives may be helpful. }\end{array}$ \\
\hline 7 & Additional Public SWM Maintenance & $\begin{array}{l}\text { Develop routines \& schedules for new activities. Public awareness } \\
\text { initiatives may increase public acceptance. }\end{array}$ \\
\hline 8 & Construct New Structural BMP's & $\begin{array}{l}\text { Construction schedule to be established. A SWM master plan would be } \\
\text { useful. Public awareness initiatives may increase public acceptance. }\end{array}$ \\
\hline 9 & Retrofit BMP Structures & $\begin{array}{l}\text { Retrofit sites and schedule to be established. A SWM master plan } \\
\text { would be useful. Public awareness initiatives may increase public } \\
\text { acceptance. }\end{array}$ \\
\hline
\end{tabular}


Table 5.9. Potential Financial Needs Resultant from Establishing Stormwater Quality Goals

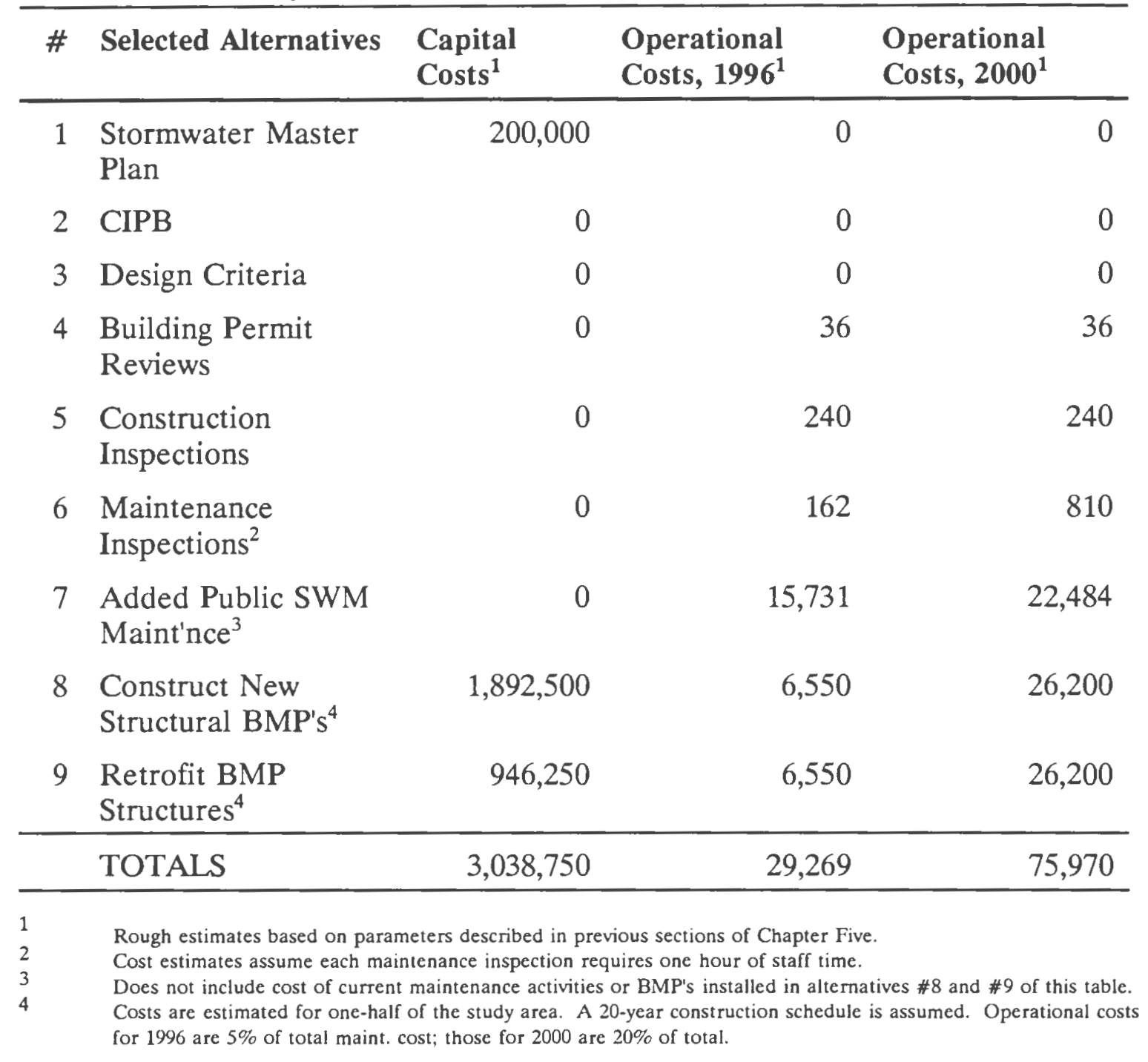




\section{Chapter Six Summary of Constraints and Opportunities}

Previous chapters have identified water quality problems in the study area, their relation to stormwater, and recommendations for addressing stormwater quality. For each recommended action, an attempt has been made to identify its potential institutional impact and financial cost. This final chapter will offer suggestions regarding possible priorities for action, in view of fiscal limitations. However, if water quality problems are to be addressed by stormwater management, some additional expense is unavoidable. Thus, suggestions for priority-setting will be followed by an overview of potential funding sources for stormwater management, and a review of organizational structures other communities have used to administer stormwater management.

\section{Suggestions for Prioritizing Alternatives}

It is suggested that priorities for implementation be developed in order to maximize benefits and minimize cost. This translates into placing greatest priority on activities that are low cost and excel in meeting water quality goals. High-cost alternatives that excel in meeting water quality goals will also be considered. Potential obstacles to implementation, other than cost or goal-attainment, will also be discussed. 


\section{Low-Cost Alternatives}

Activities with potential to substantially advance water quality goals with minimal outlay of funds include: incorporating a water quality criterion in selecting stormwater capital improvement projects, establishing stormwater design criteria to address water quality, routinizing the review of building permit applications for developments over a certain size, inspecting BMP construction at critical times, and inspecting private development to ensure proper maintenance.

Capital Improvement Projects. This activity has essentially no cost. Its capacity to meet water quality goals is limited, due to the fact that priority should be given to public safety over water quality. The only obstacle to implementation identified by this study is the possibility that restrictions on capital improvement funds may preclude incorporation of a water quality criterion.

Design Criteria. This alternative has virtually no cost, but has been described as "essential" to attaining stormwater quality goals (Hawley and McCuen, 1987). Potential obstacles to implementation include: review staff may need training; developers may oppose this option; and inter-departmental communication is required (between Departments of Planning and Public Works).

Building Permit Reviews. This alternative has minimal costs, due to the low number of additional reviews it is expected to produce. The low number expected reviews also indicates that it may have relatively little impact on water quality. Potential obstacles to implementation include developer opposition and interdepartmental communication. 
Construction Inspections. Costs associated with this alternative are high than most other "low-cost" alternatives. This cost may be justified, however, by evidence that strategically-timed inspections can prevent failure of BMP's caused by improper construction. To the extent that new development is occurring in the study area, inspections may have high impact on water quality. The fact that the study area is largely developed indicates that this option is both low cost and of limited effectiveness. Potential obstacles include: developers may oppose this option; protocols would need to be developed; and responsibilities would need to be assigned.

Maintenance Inspections. This is the most costly of the "low cost" alternatives, although it is substantially less expensive than accepting financial responsibility for maintenance of private stormwater management facilities. It is well-established that improperly-maintained BMP's fail to attain water quality goals and that ensuring regular maintenance is an integral part of any program that requires structural BMP's. Inspecting structural BMP's on private property to ensure proper maintenance occurs can potentially yield great benefits in attaining water quality goals. However, this option would only apply to properties developed after maintenance regulation was established. It would not apply to properties already developed. Other potential obstacles include: developers may oppose this option; legal authority to inspect and enforce would have to be established; protocols would need to be developed; and staff may require training.

Suggested Priorities. Of the low-cost alternatives, those which seem to have 
greatest potential for maximizing water-quality benefits are developing design criteria, inspecting BMP construction, and inspecting BMP maintenance. Since these alternatives are inter-related, it would be advisable to develop regulations that implement all three simultaneously. It is suggested that the lower-ranking alternatives also be implemented, since they are simple and low-cost.

\section{High-Cost Alternatives}

More costly activities which score high in meeting program goals include: developing a stormwater management master plan, additional maintenance of public stormwater facilities, constructing new structural BMP's, and retrofitting stormwater facilities with BMP's.

Stormwater Management Master Plan. This option has a high potential for meeting water quality goals, but only if there is a commitment to implementing recommendations made by a master plan. Another obstacle is the potential for public opposition to the expense. Problems associated with the expense of this option may be partly resolved by cooperating with other watershed communities to develop a Greenwich Bay watershed stormwater master plan.

If full implementation is not feasible, a simplified planning study could be conducted at considerably less expense. Rather than examine all dimensions of stormwater management, a survey could be conducted of stormwater management structures in priority subwatersheds (such as the Hardig Brook or Baker's Creek watersheds). The output of a simplified planning study could be proposals for 
specific retrofit projects in a priority subwatershed (Offenberg, 1995). This may include cost estimates and projected impact on water quality and flooding problems. Figure 6.1 identifies subwatersheds within the study area and the number of existing stormwater holding structures in each subwatershed.

Additional Maintenance of Public Facilities. This alternative has been described as an essential component to stormwater management for water quality. Without appropriate maintenance of stormwater facilities, they will fail. The costs are recurrent and increase as the number of stormwater structures increases. The major obstacle to this alternative is financial constraints. In the past ten years, the stormwater maintenance budget has been gradually reduced to the current level, which is not adequate to meet water quality goals. Unfortunately, this alternative will not be feasible until an institutional commitment is made to finance stormwater maintenance.

New BMP Construction. This alternative is the most costly of the high-cost alternatives, although it may yield considerable benefits in meeting water quality goals. Both water quality benefits and construction costs will vary according to where BMP's are sited and what types are used. Appropriate planning should be done to maximize benefits and minimize costs. Another potential obstacle to this alternative is the shortage of open space in the study area. Implementation of this alternative is facilitated by the commitment of $\$ 1$ million to construction and retrofitting of BMP's.

BMP Retrofitting. This is the second most expensive alternative of the high- 


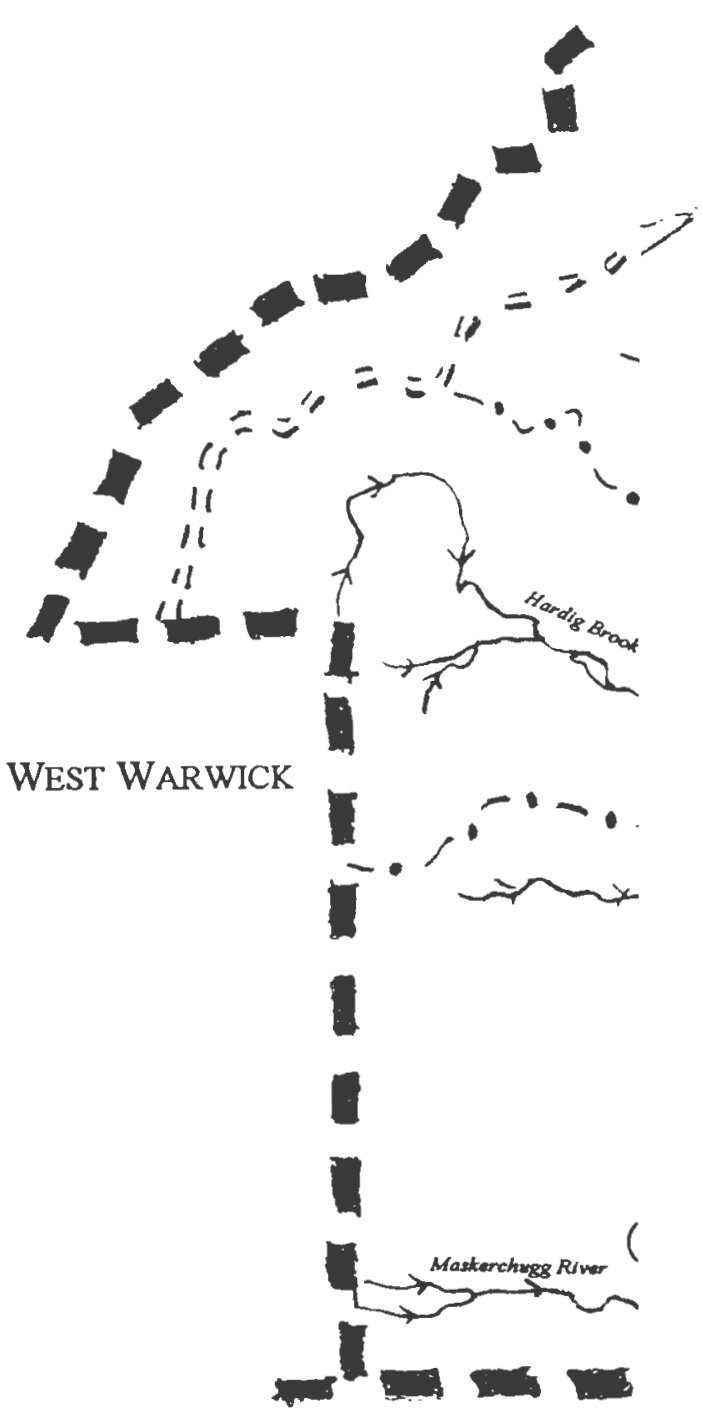

EAST C
Figure 6.1

Subbasins in Greenwich Bay Watershed

\section{Legend \\ "“ Greenwich Bay watershed boundary \\ - Subbasin boundaries \\ 7 Streams, rivers \\ Municipal boundaries \\ D Number of stormwater holding structures in subbasin}

Prepared by.

Laura Prickett

April 29, 1995

Sources:

U.S. Geologic Survey E Greenwich \& Crompton Quadrangles, 1975; M. Brusseau, Warwick Planning Dept., 1993; Master Database of Stormwater Holding Stuctures, Waraick DPW, 1995. 
cost options. This option's benefits are essentially identical to those of BMP construction. However, retrofitting tends to be substantially less expensive. Potential obstacles to implementation include shortage of space, and the fact that retrofitting may not be possible in certain critical areas.

Suggested Priorities. Of the high-cost alternatives, those with the most potential for meeting water quality goals appear to be structural BMP retrofitting and new construction. Although they can be highly effective, these options should not be implemented without ensuring appropriate maintenance will occur. Nor should they be implemented without some level of planning, in order to maximize benefits and minimize costs associated with each structural BMP.

It may be more effective to partially implement all four options described above than to select from among them. A strategic way to implement these interrelated practices would be on a subwatershed-by-subwatershed basis. Focusing restoration efforts on a few high-priority streams is likely to yield greater waterquality benefit than siting individual BMP's in numerous subwatersheds (Schueler, 1991).

\section{Overview of Potential Funding Sources}

There are a many different funding mechanisms available to local governments for capital and operating expenses. This diversity in funding mechanisms has developed, at least in part, because different funding structures are appropriate for the satisfaction of different community needs. For each option, the following 
information will be provided: a brief description of how it works, an explanation of chief advantages and disadvantages relative to stormwater management funding, and any references that may be pertinent to the specific funding option. Good general references regarding municipal finance include: Aronson and Hilley (1986) and Matzer (1984). Options are organized according to five categories: private sector contributions, intergovernmental transfers, bonds, local taxes, fees.

\section{Private Sector Contributions}

Negotiating Capital Improvements. Negotiating with developers to provide onsite and off-site improvements has become increasingly common since the 1970 s (Peterson et al., 1984; Meisner and Firtel, 1988). Such negotiations may take place during the subdivision review or development plan review process. Some states -including Maryland, Florida, and California -- have enacted legislation specifically enabling municipalities to make this bargaining process a routine part of development review. As a result of negotiated agreements during the site plan review process, some developers in Austin, Texas have constructed BMP's that treat runoff from both their own properties and adjoining land. Developers may agree to make such improvements out of a desire to do community service, or as an opportunity to promote their businesses as "environmentally-friendly" (Scharlach, 1995).

A key advantage of negotiated agreements is their flexibility. As voluntary 
contracts, they have greater capacity to meet unique needs of specific sites than fixed exactions.

Maintenance Cost-Sharing. At times it may be possible to enter into an agreement with private businesses to share the cost of maintaining public facilities. For example, a number of private businesses in Cincinnati, Ohio contributed to the cost of maintaining a public skywalk between skyscrapers. Private developers have also agreed to contribute to maintenance costs of new residential developments for a certain length of time after its construction (Peterson et al., 1984). A disadvantage to this option is that it requires special circumstances. Peterson et al. emphasize that developers generally enter into cost-sharing agreements when there are clear benefits to be gained. In the Cincinnati example, the skywalk was perceived as highly beneficial to downtown businesses. In the residential-development example, the developer wanted to ensure the properties were well-maintained until all units were sold.

Private Foundations. Private foundation grants may also be awarded to projects designed to enhance the natural environment (National Network of Grantmakers, 1989). A list of grants which may be appropriate for pollutionmitigation projects in the Greenwich Bay watershed is provided in Appendix 8.

\section{Intergovernmental Transfers}

This category includes monies obtained from state or federal government, usually in the form of grants. Intergovernmental transfers are generally well-suited 
for one-time capital expenditures. Projects designed to enhance water quality in Greenwich Bay watershed have previously qualified for two "Section 319" and Aquafund grants. Section 319 of the Federal Clean Water Act authorizes grants for nonpoint source mitigation demonstration projects. In Rhode Island, Section 319 grants are administered by RIDEM's Office of Environmental Coordination. The Rhode Island Aqua Fund also provides grants to municipalities for water pollution control projects. The Aqua Fund program is administered by RIDEM's Division of Water Resources.

The Federal Office of Management and Budget publishes a Catalog of Domestic Federal Assistance each year (OMB, 1994). This publication lists active federal grant programs by functional area. Appendix 9 provides a list of federal grants that may be applicable to stormwater management projects in the Greenwich Bay watershed.

\section{Issuing Bonds}

Infrastructure improvements are commonly made with funding obtained through long-term debt. The use of long-term debt provides intertemporal equity, since present and future beneficiaries pay for a project over its useful life. Municipal bonds are generally divided into two categories, general obligation bonds and revenue bonds. Good references regarding both types of bonds are Amdursky and Gillette (1992) and Aronson and Hilley (1986).

General Obligation Bonds. A general obligation bond is supported by the full 
revenue-raising power of the issuer. If issued by a city, it is supported by the full resources of the city; if issued by a special-purpose governmental organization, it is support by that entity's full resources. Debt service payments on both interest and principal is generally paid out of the issuer's general revenue stream. In Rhode Island, as in all other states, a limit is imposed on the general obligation debt that a municipality may incur.

Revenue Bonds. There are many different types of revenue bonds, including "special assessment bonds", "pollution control bonds", and housing revenue bonds", to name a few. Their names generally reflect the types of projects they finance, however, they have in common the fact that they are supported by the revenues generated by the facility or program being financed, rather than the full revenuegenerating power of the issuer. Payment of a revenue bond is often accomplished by establishing a special fund (also known as a sinking fund), into which the revenue from the financed facility is deposited. In Rhode Island, debts that are paid from a sinking fund are deducted in computing aggregate municipal indebtedness (RIGL 4512-2).

Many communities have financed stormwater management facilities using revenue bonds. Debt service payments on these bonds have been paid using revenue from special assessments, impact fees, or user fees (Lindsey, 1988a). The principal advantage of using revenue bonds rather than general obligation bonds is the avoidance of debt limitations. 


\section{Local Taxes}

Property Taxes. Ad valorum property taxes are the principal source of revenue for most municipalities. This revenue is typically directed to the municipal general fund and used to pay the operational expenditures for most functions of local government. Municipal governments usually allocate money from the general fund according to a general budget, which is developed by the legislative body each year.

The general fund is an appropriate source of funding for expenditures that benefit all residents equally. Although it is usually considered an inappropriate source of funds for capital expenditures, a portion of the general fund is typically used to make debt service payments on general obligation bonds. A key disadvantage of using property taxes to finance stormwater management activities is the fact that all municipal departments compete for these funds. The annual formulation of a municipal budget tends to be a highly politicized process, and there is no guarantee that a constant level of funding will be allocated to stormwater management from year to year. Operational expenditures for stormwater management have historically been under-funded by municipal budgets (Engemoen and Krempel, 1985; Lindsey, 1988; ASCE and WEF, 1992).

Special Assessments. A special assessment is essentially an exaction based on benefits received by the payer (Gillette, 1994). Courts have determined that special assessments should be considered a type of tax rather than a fee (Yard, 1991). Properties determined to benefit from a project are assessed accordingly. The municipal government links this revenue to payment for the project, rather than 
crediting it to the general fund. Special assessments are frequently used to pay debt service on revenue bonds.

Special assessments are best suited to situations in which a capital improvement confers a distinct benefit on properties in a geographic subsection of a municipality. Those benefitted pay for the improvement; the rest of the community theoretically is not benefitted and does not pay. Although special assessments are typically used to finance capital improvements, they have also been used to pay for operational expenses (Gillette, 1994).

Where special assessments have been challenged by lawsuits, courts have generally examined the nature of the benefit received by assessed properties. The legitimacy of special assessments for stormwater management improvements and operations have been upheld in several cases (Gillette, 1994; Yard, 1991). A court ruling in Florida held that stormwater special assessments are a tax and therefore cannot be made on property owned by the state government or other tax-exempt entities (Yard, 1991).

Tax Refunds. A community may offer tax refunds to property owners who retrofit stormwater management facilities to enhance water quality or repair failing septic systems (Eastern Research Group, 1991). The principal advantage of this option is that it does not impose new or increased taxes or fees on property owners. Although private installations of structural BMP's may save the city some BMPconstruction expenses, the loss of revenue to the general fund may be unacceptable. 


\section{Fee Options}

In general, fees are charged by municipal governments to the recipients of goods or services provided by the municipality. From a legal perspective, fees differ from taxes in that taxes are designed to generate revenue, whereas, fees reflect the cost to the municipality of providing specific goods or services (Gillette, 1994). The basis for a fee may be conceived of as a measure of benefits that recipients enjoy, or as a measure of the costs that recipients have caused a municipality to incur.

Impact Fees. Impact fees have been defined as "charges imposed by local government on new development to recoup or offset a proportionate share of public capital costs required to accommodate such development with necessary public facilities" (Nicholas, 1988). The objective of an impact fee is not to raise money but to ensure the provision of adequate capital facilities. In order to formulate a sound impact fee, clear documentation should be made of capital costs to be offset by the fee, and of the proportionate share required to accommodate specific developments or classes of development.

Impact fees have enabled many communities to provide necessary infrastructure without disproportionate increases in property taxes. These fees are best-suited to offset capital expenditures. In reviewing impact-fee literature, there is no evidence that such fees have been used to defray operational costs. Nicholas (1988) provides an excellent overview of this subject. Important legal considerations are also discussed by Gillette (1994).

In-Lieu-of-Fees. This option allows private developers to pay a fee to the 
local government in lieu of constructing infrastructure that would normally be required on-site. In-lieu-of payments are generally placed in funds designated for specific capital projects.

A key advantage to this option is that developers often prefer paying in-lieu-of fees to constructing BMP's. On the other hand, it is not always feasible to construct a public stormwater management structure to capture runoff from developments that choose to pay this fee. This option may result in numerous developments with unmitigated stormwater runoff impacts (Scharlach, 1995). Experiences of communities that have adopted this practice, such as Austin, Texas could be valuable in determining whether and/or how to adopt it.

User Fees. A user fee may be defined as "a price charged by a governmental agency for a service or product whose distribution it controls" (Gillette, 1994). User fees are based on the linkage between use of a specific service and the rate each user is charged. Yard (1991) has observed that user fees may be more appropriate than special assessments in funding stormwater management. While the use of special assessments must be based on benefits accrued by the payer, user fees may be based on the need created by the impervious surface on the payer's land. In 1981 national survey found that $55 \%$ of Americans would prefer to have local services financed by user fees rather than property tax increases. Holland attributes this preference primarily to the linkage between use and payment.

Communities that charge user fees for stormwater management typically charge higher rates for properties with greater percentages of impervious surface. 
This is generally estimated according to land use classifications, although impervious acreage may be calculated by using geographical information systems and data from aerial photographs (Kienegger, 1992).

Two additional advantages of this mechanism should also be noted. Fees do not change if property values increase, and developers have an added incentive to mitigate amounts of impervious surfaces when developing or re-developing a site. Disadvantages include: the public may resist the establishment of a new fee; unlike payment of property taxes, the payment of fees can not be deducted from federal income taxes; and 3) local governments may find the cost of administering and collecting a new fee undesirable. Authors that provide useful information regarding user fees include Gillette (1994), Yard (1991), Holland (1982), and Downing and Lorenzo (1981).

\section{Review of Organizational Structures}

Some communities have found that stormwater problems can be better managed by creating separate stormwater organizations, or divisions within existing organizations. This section will review the advantages and disadvantages of three organizational options: the stormwater utility concept, special districts, and specialpurpose governments. It will conclude with a discussion of advantages and disadvantages associated with maintaining the DPW's existing organizational structure.

The "Stormwater Utility" Concept. In the search for a reliable source of 
stormwater management funding, many communities have employed a "stormwater utility" concept. Some communities have actually created a new organization, while others have made some modifications to existing stormwater management programs. While there is considerable diversity among them (Lindsey, 1988a), "stormwater utilities" generally share these attributes: 1) they have a specific, articulated mission of managing stormwater, 2) their operations are funded by a dedicated source of revenue, usually from user fees or special assessments, and 3) they are responsible for capital improvements and operations and maintenance of the public stormwater system (Poertner, 1981; Lindsey, 1988a, Hansen, 1991).

Some examples of variations in stormwater utilities have been documented by Lindsey (1988a), in the results of a survey of nineteen stormwater utilities throughout the country. The majority of utilities surveyed were located in a department of utilities, along with water and sewer service. Several were located in a department of public works, or reported to the director of public works. A majority of stormwater utilities surveyed had responsibility for regulation and enforcement of stormwater management, as well as operations and maintenance. Some utilities surveyed were quasi-governmental agencies with authority to issue bonds for capital improvements, and some financed capital improvements through bonds issued by the city government. A number of utilities reported interest income on investments as a source of revenue, in addition to user fees or special assessments. Most of the utilities surveyed conduct public relations programs.

Two principal advantages of the stormwater utility approach have been 
identified. Stormwater management is less likely to be neglected since it is the primary concern of a governmental unit, and a dedicated source of funding ensures that all necessary stormwater management activities may be conducted. There are also noteworthy disadvantages. The public may respond negatively to a stormwater fee, and organizing a utility program and administering fees may be undesirable for local officials. There are many good references regarding the stormwater utility concept. Lindsey (1988b), Pyzoha (1994), and Yard (1991) provide particularly helpful explanations.

Special Improvement Districts. Special improvement districts are often created in order to finance improvements specific to one section of a city. Special assessments may be made on the properties within such a district. Another way to finance improvements is to dedicate an increment of the property tax revenue from the district to a specific improvement. Revenue bonds are often issued for such projects, supported by these sources of revenue. A key advantage of this administrative option is that a project is paid for by those who enjoy its benefit. This option is not appropriate where benefits are not clearly enjoyed by a distinct geographical section of the community.

Special-Purpose Governmental Agencies. An independent authority, with the power to raise capital and the responsibility of establishing prices, generally offers bond buyers more security than a service system that is operated as part of the general city budget. Thus, such agencies can generally issue bonds with interest rates lower than those of municipal revenue bonds (Peterson et al., 1984). Authorities may 
be established with service areas that cross municipal boundaries. This type of agency may be desirable in order to address water pollution problems of an entire watershed.

In order to fund stormwater projects at lower interest rates, some municipalities have created separate stormwater agencies with the power to issue debt. Others have transferred the stormwater function to agencies that already have this power. There are, however, disadvantages to this option. Special-purpose governmental agencies are not directly accountable to the public. Also, an agency's mandate to manage a single aspect of local government may, at times, conflict with the local government's efforts to meet the overall needs of a community (Peterson et al., 1984).

\section{Existing Structure of the DPW}

The organizational structure of the DPW was examined in Chapter Three, with an emphasis on functions relating to stormwater management. It was found that there is no mission statement regarding stormwater management and that stormwater management functions are divided primarily among two divisions, Engineering and Highways. The DPW Director is ultimately responsible for approving work orders for drainage repairs and determining which stormwater capital improvement projects should be undertaken.

There are several advantages of maintaining the organizational status quo. Personnel are familiar with their assignments, and drastic changes would disrupt the 
Department's normal flow of activities. Combining road-construction and stormwater-construction duties within the Highways Division allows for some combinations of projects, which saves time and expense. Combining road-design and stormwater-design projects within the Engineering Division has similar beneficial results.

Two aspects of the existing organizational structure may constitute disadvantages for managing stormwater quality problems. Since stormwater problems are not the primary concern of any office or individual within the Department, addressing these problems may be delayed in favor of higher-priority items. Secondly, since stormwater management evolved as an aspect of highway construction and maintenance, it was not included in the City Charter's mission statement for the DPW, and its relation to water quality has historically received little attention.

\section{Conclusion}

This study has considered the potential benefits that changes in stormwater management practices may have on Greenwich Bay's water quality, as well as the impacts they may have on the existing stormwater management program. Chapter One laid the foundation for the study, noting signs of increased public awareness of pollution in Greenwich Bay and institutional commitment to addressing pollution problems. Chapter Two identified the major stormwater problems in Greenwich Bay. It was also observed that anticipated federal regulations -- regarding stormwater discharges (RIPDES) and the coastal zone $(6217(\mathrm{~g}))$-- may require Warwick to take 
some of the actions recommended by this study. Chapter Three described the existing stormwater management program. Chapters Four and Five identified stormwater best management practices (BMP's) for water quality that would be appropriate to incorporate into the existing program.

This final chapter has attempted to bridge the gap between recommendations and action. First, a framework was provided for prioritizing recommended stormwater management practices for water quality. It was observed that several actions to help improve water quality can be taken at no cost or low cost, and that substantial funds have already been allocated for construction of structural BMP's. However, it was also observed that proper maintenance of existing and future stormwater structures will require a commitment of funds.

The second section of this chapter provided an overview of revenue-generating options for implementing stormwater management practices. Some options are more appropriate for capital expenses and some for operational expenses, including maintenance. Options that may be appropriate to cover maintenance costs include private-sector cost sharing, property taxes, special assessments, and user fees.

Finally, a review was made of various organizational structures that have been used to administer stormwater management programs. It was observed that where stormwater management is the primary concern of an organization, division, or individual, stormwater management problems are more likely to receive adequate attention. It was also observed that structural changes within an organization may be time-consuming and difficult, and may create new problems. 
While the BMP's selected for implementation in Chatper Five are expected to have a positive impact on water quality, the value of implementing BMP's that were outside the scope of this project should not be overlooked. Among these are enforcement of septic system maintenance and repair, promotion of water conservation and bay-friendly lawn-care practices, and reduction of animal waste. These BMP's were not considered for implementation because they appeared to fall under the purview of municipal programs other than stormwater management.

Not only was the focus of this study limited by functional area, but it was also limited in geographic scope. Recommendations have been made primarily for the Greenwich Bay watershed within the City of Warwick. It is important to note that any recommended action Warwick chooses to implement could be more effective if it were also implemented by other municipalities within the watershed. 
APPENDIX 1

Land Uses in the Study Area

Table A.1. Approximation of Land-Use Distribution in Study Area

\begin{tabular}{|c|c|c|c|}
\hline $\begin{array}{l}\text { Land Uses in Warwict ( }+ \text { small part of } \mathbf{E} \\
\text { Greenwich } 1,2\end{array}$ & Sq. Miles & Acres & Percent \\
\hline High Density Residential ( $<1 / 8$ acre lots) & 0.776 & 496.985 & 4.3 \\
\hline Medium High Density Res. (1/8-1/4 acre lots) & 4.782 & 3060.184 & 26.2 \\
\hline Medium Density Res. (1/4 to 1 acre lots) & 2.690 & 1721.695 & 14.7 \\
\hline Medium Low Density Res. (1 to 2 acre lots) & 0.310 & 198.130 & 1.7 \\
\hline Low Density Res. ( $>2$ acre lots) & 0.047 & 30.084 & 0.3 \\
\hline Commercial & 1.145 & 732.552 & 6.3 \\
\hline Industrial & 0.101 & 64.480 & 0.6 \\
\hline Roads & 0.616 & 393.953 & 3.4 \\
\hline Airports & 0.233 & 149.026 & 1.3 \\
\hline Water and Sewage Treatment & 0.017 & 10.765 & 0.1 \\
\hline Waste Disposal & 0.009 & 5.603 & 0.1 \\
\hline Power Lines & 0.126 & 80.620 & 0.7 \\
\hline Other Transportation & 0.026 & 16.477 & 0.1 \\
\hline Commercial/Industrial Mix & 0.087 & 55.567 & 0.5 \\
\hline Developed Recreation & 1.148 & 734.420 & 6.3 \\
\hline Vacant Land & 0.022 & 13.961 & 0.1 \\
\hline Cemeteries & 0.072 & 46.209 & 0.4 \\
\hline Institutional & 0.426 & 272.600 & 2.3 \\
\hline Pasture & 0.225 & 144.174 & 1.2 \\
\hline Cropland & 0.123 & 78.799 & 0.7 \\
\hline Orchards, Nurseries & 0.029 & 18.772 & 0.2 \\
\hline Idle Agriculture & 0.053 & 33.790 & 0.3 \\
\hline Deciduous Forest & 2.462 & 1575.454 & 13.5 \\
\hline Evergreen Forest & 0.083 & 53.132 & 0.5 \\
\hline Mixed Deciduous & 0.447 & 285.991 & 2.5 \\
\hline Mixed Evergreen & 0.202 & 128.983 & 1.1 \\
\hline Brushland & 0.256 & 163.992 & 1.4 \\
\hline Wetland & 1.338 & 856.276 & 7.3 \\
\hline Beaches & 0.034 & 21.485 & 0.2 \\
\hline Sandy Areas & 0.022 & 14.270 & 0.1 \\
\hline
\end{tabular}




\begin{tabular}{|c|c|c|c|}
\hline $\begin{array}{l}\text { Land Uses in Warwick ( }+ \text { small part of } E \\
\text { Greenwich } 1,2\end{array}$ & Sq. Miles & Acres & Percent \\
\hline Mines, Gravel Pits & 0.113 & 72.252 & 0.6 \\
\hline Transitional Areas & 0.248 & 158.806 & 1.4 \\
\hline Other & 0.001 & 0.566 & 0.0 \\
\hline TOTALS & 18.269 & $11,690.053$ & $100.4^{3}$ \\
\hline
\end{tabular}

1 It was not technically feasible to fully separate community land use data.

2 Open water in study area not included. Total open water $=5.204$ square miles, or 333.059 acres.

3 Rounding-off of numbers caused total to exceed $100 \%$.

Source: RIGIS database, last updated in 1988. 
APPENDIX 2

Developed Land in the Study Area

Table A.2. Approximation of Amount of Developed Land in Study Area

\begin{tabular}{|c|c|c|c|}
\hline $\begin{array}{l}\text { Land Uses in Warwick ( }+ \text { small part of } E \\
\text { Greenwich) }\end{array}$ & Sq. Miles & Acres & \% of Study Area \\
\hline High Density Residential ( $<1 / 8$ acre lots) & 0.776 & 496.985 & 4.3 \\
\hline Medium High Density Res. (1/8-1/4 acre lots) & 4.782 & 3060.184 & 26.2 \\
\hline Medium Density Res. (1/4 to 1 acre lots) & 2.690 & 1721.695 & 14.7 \\
\hline Medium Low Density Res. ( 1 to 2 acre lots) & 0.310 & 198.130 & 1.7 \\
\hline Low Density Res. ( $>2$ acre lots) & 0.047 & 30.084 & 0.3 \\
\hline Commercial & 1.145 & 732.552 & 6.3 \\
\hline Industrial & 0.101 & 64.480 & 0.6 \\
\hline Roads & 0.616 & 393.953 & 3.4 \\
\hline Airports & 0.233 & 149.026 & 1.3 \\
\hline Water and Sewage Treatment & 0.017 & 10.765 & 0.1 \\
\hline Waste Disposal & 0.009 & 5.603 & 0.1 \\
\hline Other Transportation & 0.026 & 16.477 & 0.1 \\
\hline Commercial/Industrial Mix & 0.087 & 55.567 & 0.5 \\
\hline Developed Recreation & 1.148 & 734.420 & 6.3 \\
\hline Cemeteries & 0.072 & 46.209 & 0.4 \\
\hline Institutional & 0.426 & 272.600 & 2.3 \\
\hline Mines, Gravel Pits & 0.113 & 72.252 & 0.6 \\
\hline Other & 0.001 & 0.566 & 0.0 \\
\hline TOTALS & 12599 & $8,061.548$ & 69.0 \\
\hline
\end{tabular}

1 It was not technically feasible to fully separate community land use data.

Source: RIGIS database, last updated in 1988. 


\section{APPENDIX 3}

\section{Undeveloped Land in the Study Area}

Table A.3. Approximation of Amount of Undeveloped Land in Study Area

\begin{tabular}{|c|c|c|c|}
\hline $\begin{array}{l}\text { Land Uses in Warwick (+ small part of } E \\
\text { Greenwich) }\end{array}$ & Sq. Miles & Actes & Percent \\
\hline Power Lines & 0.126 & 80.620 & 0.7 \\
\hline Vacant Land & 0.022 & 13.961 & 0.1 \\
\hline Pasture & 0.225 & 114.174 & 1.2 \\
\hline Cropland & 0.123 & 78.799 & 0.7 \\
\hline Orchards, Nurseries & 0.029 & 18.772 & 0.2 \\
\hline Idle Agriculture & 0.053 & 33.790 & 0.3 \\
\hline Deciduous Forest & 2.462 & 1575.454 & 13.5 \\
\hline Evergreen Forest & 0.083 & 53.132 & 0.5 \\
\hline Mixed Deciduous & 0.447 & 285.991 & 2.5 \\
\hline Mixed Evergreen & 0.202 & 128.983 & 1.1 \\
\hline Brushland & 0.256 & 163.992 & 1.4 \\
\hline Wetland & 1.338 & 856.276 & 7.3 \\
\hline Beaches & 0.034 & 21.485 & 0.2 \\
\hline Sandy Areas & 0.022 & 14.270 & 0.1 \\
\hline Transitional Areas & 0.248 & 158.806 & 1.4 \\
\hline Total & 5.670 & $3,598.505$ & 31.0 \\
\hline
\end{tabular}

1 It was not technically feasible to fully separate community land use data.

2 Open water in study area not included. Total open water $=5.204$

Source: RIGIS database, last updated in 1988. 


\title{
APPENDIX 4 \\ Stormwater Holding Structures in Warwick
}

\author{
CITY OF WARWICK \\ DEPT. OF PUBLIC WORKS \\ ENGINEERING DIV. \\ 1 APRIL 1995 \\ "BASINDAT . WP"
}

The file [basindat.wk4], which is stored in Lotus [ver. 4] on the Gateway P.C., is a master compilation of all the available data on stormwater holding basin structures, both public and private, existing and proposed, that are situated in the City of Warwick, State of Rhode Island.

This file lists each area by a map reference number, with a location name, type of structure, plat and lot, and the receiving watershed. There are 87 site locations to date.

The total number of actual structures is 133, of which 16 are considered preliminary, to date. Of these, 82 are privately owned, 46 are City owned, 3 are state owned, and 1 is Federally owned. There are 66 detention basins- these hold stormwater temporarily in a manmade basin, releasing this water by controlled discharge. There are 27 retention basins- these hold water indefinitely. usually until evaporation occurs. Underground structures- leaching chambers [galleys] or leaching drains, and multiple drywell systems-total 19 in the city. Infiltration basins [leaching fields] and sediment trapping basins, total 8. There are 7 flow spreading structures; and 5 natural holding ponds [wetlands or drainage swales] in the City.

The drainage holding basin book [filed in Engineering] contains different map indices for locating each site, along with lists that reference the unit, and numbered pages showing structural detail. Also included in the book are: watershed/topographic map; open surface structure list for mosquito abatement [not updated]; and a list with maps for all City maintained basins [drain.wk4-separate tabulation].

Other related data: Refer to the R.I.D.E.M. Underground Injection Control Program; also refer to article on urban stormwater Pollution Regulations for Municipalities. A separate tabulation has been compiled [not updated] for drainage basins being studied for mosquito control. See also the City Engineer's stormater file; a listing of natural drainage features in the City of warwick has been compiled, showing map grid locations [refer to flle "drain2.wk4"]. 


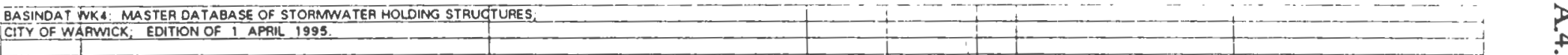

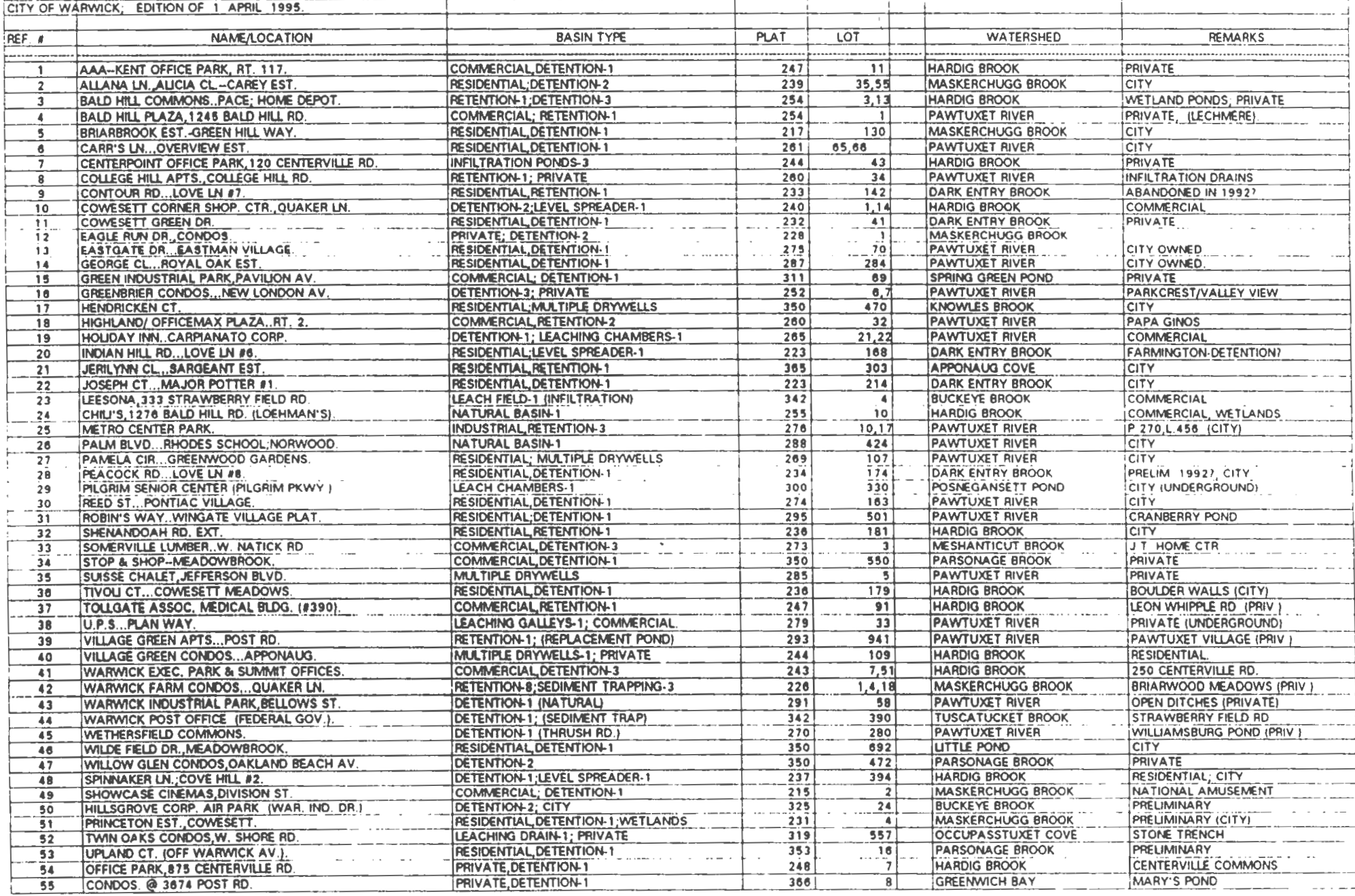




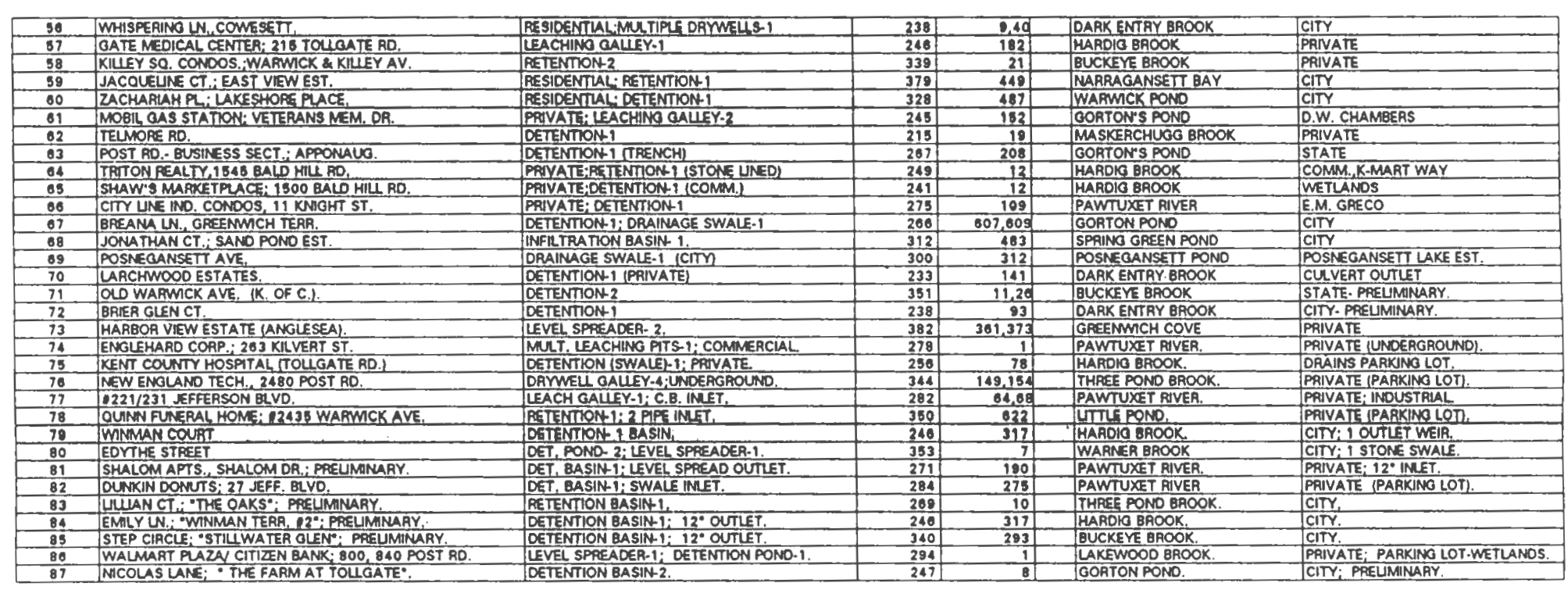




\section{APPENDIX 5 \\ Stormwater Holding Structures in the Study Area}

Table A.5. Stormwater Holding Structures in Study Area.

\begin{tabular}{|c|c|c|}
\hline Nampllocition & $B \operatorname{sen} T$ Tpes & wemerend \\
\hline Indian HillzLove Ln. & Level spreader-1 & Dark Enty \\
\hline Joseph Ct Maj. Potter & Detention-1 & Dark Entry \\
\hline Comesett Green Dr. & Detention-1 & Dark Entry \\
\hline Larchwood Est & Detention-1 & Dark Entry \\
\hline Contour Rd...Love Lane & Retention-1 & Dark Entry \\
\hline Peacock Rd...Love Ln.\#B & Detention-1 & Dark Entry \\
\hline Whispering LR.Cowesett & Multiple drymell & Dark Entry \\
\hline Brier Glen Ct & Detention-1 & Dark Entry \\
\hline Mobil Sta, VotMem. & Leaching galley-2 & Gorton Pond \\
\hline Nicolas Ln.Farm@Tollgate & Detention basin-2 & Gorton Pond \\
\hline Breana Ln., Greenwich Terr. & Detention-1,Swal $\theta-1$ & Gorton Pond \\
\hline Post Rd.,Bus.Sect, Appo & Detention-1(trench) & Gorton Pond \\
\hline Condos.@3674 Post Rd. & Private, Detention-1 & Greenwich Bay \\
\hline Harbor View Est (Anglesea) & Level spreader-2 & Grnwich Cove \\
\hline Tivoli Ch Comest Meadows & Res.,Detention-1 & Hardig Brook \\
\hline Shenandoah Rd.Ext & Res., Pretention-1 & Hardig Brook \\
\hline Spinnaker Ln., Cove Hill \#2 & Detentr-1,Lvi spreader & Hardig Brook \\
\hline CowesstComer Shop, Qukr Ln & Detentr-2.LV spreadr & Hardig Brook \\
\hline Shaws, 1500 Bald Hill & Detentn-1 & Hardig Brook \\
\hline Warw. Exec.Pk\&Summit Ofc & Detention-3 & Hardig Brook \\
\hline Centerpt.Orc.Pk, 120 Centrvil & Infttrn ponds-3 & Hardig Brook \\
\hline VillageGreen condos,Appo. & Mutiple drywells-1 & Hardig Brook \\
\hline Gate MedCr..Tollgate & Leaching galley-1 & Mardig Brook \\
\hline Winman $C t$ & Detention-1 & Hardig Brook \\
\hline Emily Ln,Winman Terr & Detention-1,12 outiet & Mardig Brook \\
\hline AAA-Kent OrcPk, Rte 117 & Comm.Dotention-1] & Hardig Brook \\
\hline TollgataAssoca Med. Bldg. & Comm.,Retention-1 & Hardig Brook \\
\hline Ofc Park, 875 Cntrull Rd. & Private, Detention-1 & Hardig Brook \\
\hline TritonPealty, 1545 Bald Hill & Retention-1 & Mardig Brook \\
\hline Bald Hill Commons & Retentr-1,Detentr-3 & Mardig Brook \\
\hline Chilis, 1276 Bald Hill Rd' & Natural Basin-1 & Hardig Brook \\
\hline Kent Cty Hosp (Tollgate Rd) & Detention(swale)-1 & Herdig Brook \\
\hline
\end{tabular}

Source: Master Data Base of Stormwater Holding Structures, City of Warwick, April 1, 1995 
Menerlocedon

Shourcase Cinem, Divisn St

Telmore Rd.

Briartrook Est, Green Hill

Warwick Farm Condos-Qukthn.

Eagle Run Dr. Condos.

Princeton Est Coweset

AlanaLn/AliciaCl-CareyEst

Wanwick Post Ofc.
Dein Type

Detention-1

Detention-1

Delentn-1

Retentn-8,Sed.trap

Private, Detention-2

Detentn-1, Wetinds

Detention-1, Wtiands

Detentn-1 (sed.trap)
Werented

Maskerchugg

Maskerchugg

Maskerchugg

Maskerchugg

Maskerchugg

Maskerchugg

Maskerchugg

Tuscatucket 


\section{APPENDIX 6 \\ Maintenance Checklist}

Table A.6. Maintenance Activities and Frequency of Performance in Warwick

Maintenance Activity

\begin{tabular}{lrr}
\hline \multicolumn{1}{c}{ Maintenance Activity } & \multicolumn{2}{c}{ Frequency per Year } \\
& Recommended & Implemented $^{2}$ \\
\hline Clean catch basins & $1.25-1.50$ & 1.00 \\
Clean inlets and sumps & 1.00 & 1.00 \\
Detention basins: underground cleaning & 0.50 & Sometimes \\
Detention basins: vegetation control & $1.50-2.00$ & 0.00 \\
Detention basins: remove sedimention & $0.20-0.50$ & 0.00 \\
Clean oil separators & 1.00 & 1.00 \\
Clean outfalls & 1.50 & 1.00 \\
Roadside ditches: vegetation control & $1.00-3.00$ & 1.00 \\
Roadside ditches: clean, reshape, remove & $0.25-0.33$ & 1.00 \\
sedimentation & & \\
Open channels, creeks: veg. control & 3.00 & Sometimes \\
Open channels, creeks: clean, reshape and & $0.33-1.00$ & Sometimes \\
remove sedimentation & & \\
Clean/flush culverts under 18" & 0.50 & 1.00 \\
Clean/flush culverts 18" \& larger & 0.50 & 1.00 \\
Clean pipe under 18" & 0.25 & 1.00 \\
Clean pipe 18" and larger & 0.33 & 1.00 \\
Repair, replace catch basin & 1.00 & 1.00 \\
Repair, replace manholes & 1.00 & 1.00 \\
Street sweeping & $4.00-6.00$ & 1.50 \\
\hline 1 Frequency recommended by Pyzoha, 1994 and Washington County, OR (no date). & & \\
2 Frequere sources differ, a range is given. \\
Sources:
\end{tabular}

Frequency per Year 


\section{APPENDIX 7 \\ Schedule of Building Permit Fees}

SCHEDULE OF PERMIT FEES
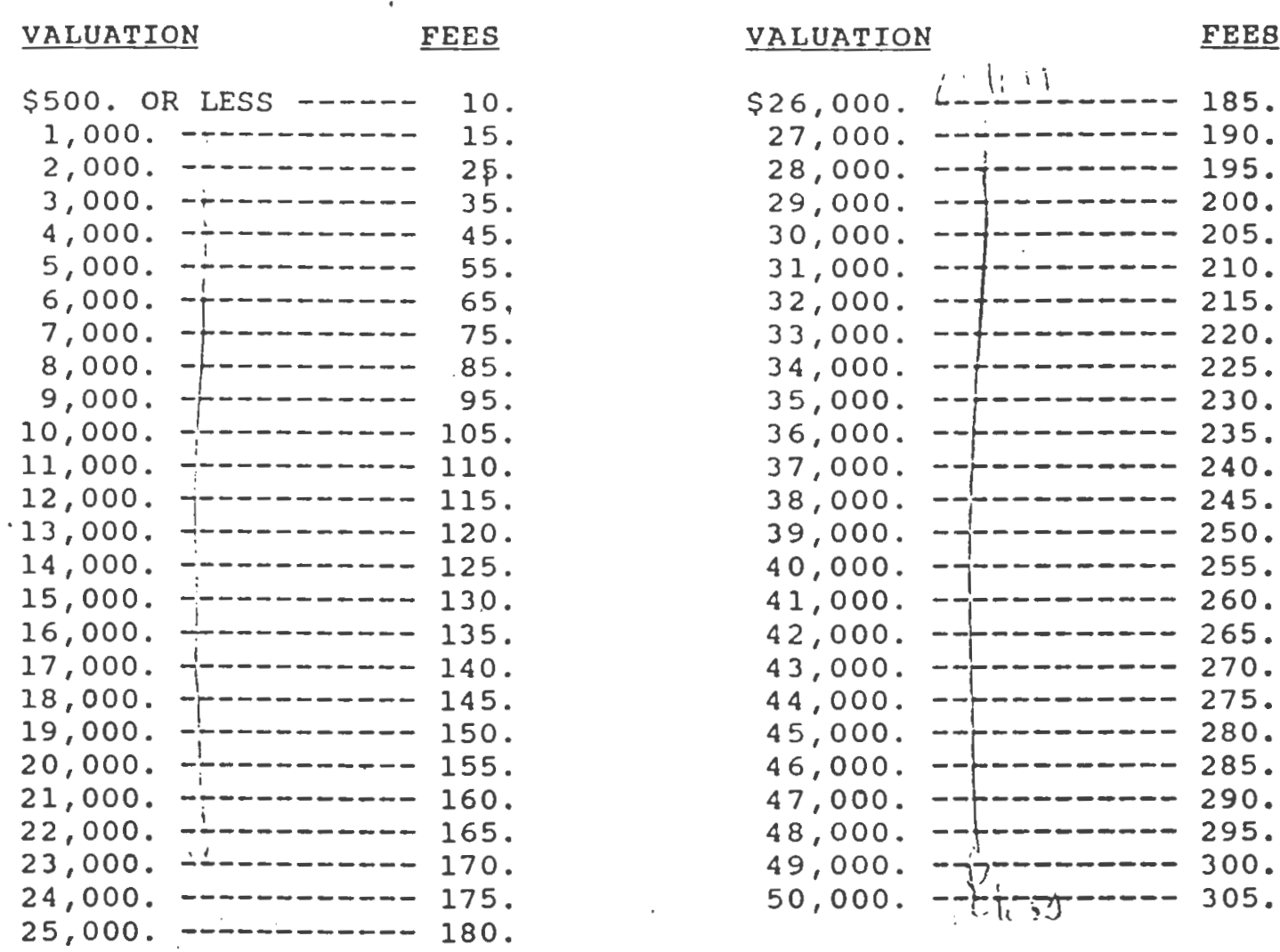

$\$ 50,000$. to $\$ 100,000$. - $\$ 305$. plus $\$ 8.00$ for each $\$ 1,000$. over $\$ 50,000$. and not over $\$ 100,000$.

$\$ 100,001$. to $\$ 500,000$. - - $\$ 705$. plus $\$ 6.00$ for each $\$ 1,000$. over $\$ 100,001$. and not over $\$ 500,000$.

$\$ 500,001$. to No LIMIT -- $\$ 3,705$. plus $\$ 4.00$ for each $\$ 1,000$. over $\$ 500,001$.

PERMIT FEES BASED ON VALUATION OF CURRENT CONSTRUCTION COBT

SIGNS 10 square feet.

$\begin{array}{lll}\text { CERTIFICATE OF OCCUPANCY: } & \text { Residential } & \$ 5.00 \\ & \text { Commercial } & \$ 10.00\end{array}$

NOTE: $\quad$ Add $0.001 \times$ valuation for State fee (CE/ADA). 


\section{APPENDIX 8 \\ Private Grant-Making Organizations}

Table A.7. Private Grant-Making Organizations with Environmental Interests

\begin{tabular}{|c|c|c|}
\hline Organization & Applicant Eligibility & Relevant Interests \\
\hline $\begin{array}{l}\text { HKH Foundation } \\
\text { Harriet S. Barlow, Adviser } \\
33 \text { Irving Pl., 10th Fl. } \\
\text { New York, NY } 10003 \\
518-352-7391\end{array}$ & $\begin{array}{l}\text { Individuals not eligible. Policies } \\
\text { outlined in form letter. }\end{array}$ & Environmental protection. \\
\hline $\begin{array}{l}\text { W. Alton Jones Poundation, Inc. } \\
\text { R. Jeffrey Kelleher, Director } \\
433 \text { Park St. } \\
\text { Charlottesville, VA } 22901 \\
\text { 804-295-2134 }\end{array}$ & $\begin{array}{l}\text { Individuals, conduit organizations not } \\
\text { eligible. No support for building } \\
\text { construction, renovation. Guidelines, } \\
\text { annual report available. }\end{array}$ & $\begin{array}{l}\text { Sustainability, biological } \\
\text { diversity; water-pollution } \\
\text { control. }\end{array}$ \\
\hline $\begin{array}{l}\text { The McIntosh Foundation } \\
\text { Michael A. McIntosh, President } \\
\text { 215 Fifth St. Ste. } 100 \\
\text { W. Palm Beach, FL } 33401 \\
\text { 305-832-8845 }\end{array}$ & $\begin{array}{l}\text { Individuals not eligible. No support for } \\
\text { endowments, building funds. Policy } \\
\text { statement and guidelines available. }\end{array}$ & Conservation. \\
\hline $\begin{array}{l}\text { The Charles Stewart Mott Poundation } \\
\text { Judy Y. Samelson, Director of } \\
\text { Communications } \\
1200 \text { Mott Foundation Building } \\
\text { Flint, MI } 48502-1851 \\
\text { 313-238-5651 }\end{array}$ & $\begin{array}{l}\text { Potential applicants determine } \\
\text { eligibility by reading annual report. }\end{array}$ & $\begin{array}{l}\text { Sustainable environment; } \\
\text { action-oriented, state-of- } \\
\text { the-art initiatives. }\end{array}$ \\
\hline $\begin{array}{l}\text { South Branch Foundation } \\
\text { Peter S. Johnson, Administrator } \\
\text { c/o Gillen and Johnson } \\
\text { P.O. Box } 477 \\
\text { Somerville, NJ } 08876 \\
201-722-6400\end{array}$ & $\begin{array}{l}\text { Individuals not eligible. No support for } \\
\text { building funds. No publications } \\
\text { available. }\end{array}$ & $\begin{array}{l}\text { Conservation; } \\
\text { environmental protection } \\
\text { and advocacy. }\end{array}$ \\
\hline $\begin{array}{l}\text { The Stanky Works Foundation } \\
\text { Ronald F. Gilrain, Vice Pres., Public Affairs } \\
\text { c/o Connecticut Bank and Trust Co. } \\
\text { Hartford, CT } 06103 \\
203-225-5111\end{array}$ & $\begin{array}{l}\text { "Community funds" are eligible. No } \\
\text { support for operating budgets, } \\
\text { equipment, land acquisition, } \\
\text { renovations, publications, conferences. }\end{array}$ & "The environment" \\
\hline $\begin{array}{l}\text { Town Creek Poundation } \\
\text { Edmund A. Stanley, Jr., President } \\
\text { P.O. Box } 159 \\
\text { Oxford, MD } 21654\end{array}$ & $\begin{array}{l}\text { Individuals, 'private foundations', } \\
\text { schools, capital-fund campaigns not } \\
\text { eligible. Brochure available. }\end{array}$ & $\begin{array}{l}\text { Preservation \& } \\
\text { enhancement of } \\
\text { environment; informing the } \\
\text { public. }\end{array}$ \\
\hline
\end{tabular}

Sources: $\quad$ National Network of Grantmakers, 1989; The Foundation Center, 1990. 


\section{APPENDIX 9 \\ Federal Grants}

\section{Table A.8. Federal Grants for which Greenwich Bay Initiatives May Be Eligible}

Grant / Agrency

Research Information/ Dept. of Interior National Biological Survey Washington, DC 20240

202-482-2348

Water Pollution Control - Research, Development and Demonstration/ US EPA Office of Research and Development Washington, DC 20460 202-260-7473

Water Resources Research Grant Program/

Dept. of Interior Geological Survey

\section{National Coastal Wetlands}

Conservation Grants/

Dept. of Interior U.S. Fish and

Wildlife Service

National Pollutant Discharge Elimination System Related State Program Grants/

US EPA Office of Water

Nonpoint Source Implementation (319) Grants/

US EPA Office of Water

Sport Fish Restoration/

Dept. of Interior U.S. Fish and

Wildlife Service

Wetlands Protection - State

Development Grants/

US EPA Office of Water

Water Research Institute Program/ Dept. of Interior Geological Survey

Environmental Justice Grants to Small Community Groups/ US EPA Office of Environmental Justice

Washington, DC 20460

202-260-6357
Local \& state govts eligible. Each state has official/office designated as point of contact. Federal funds shall not exceed $75 \%$

Local or state govts eligible if qualifications are adequate to perform the research. Dollar-fordollar match required.

Coastal states eligible; local govts. not beneficiaries. Federal share $=$ up to $50 \%$, up to $75 \%$ if state has trust fund for open space acquisition.

States eligible; local govts not beneficiaries. No matching requirement.

States eligible \& may select beneficiaries, including local govts. At least $40 \%$ of funds must be nonfederal.

State fish \& wildlife agencies eligible. No beneficiaries. State matching funds based on formula.

State agencies (with 401 certification) eligible. Local govts not beneficiaries. Minimum state match $=20 \%$.

Designated University Water Research Institutes eligible. Other educational institutes may be beneficiaries. Federal share $=1 / 3$.

Community groups, nonprofit institutions eligible. Federal share $=$ up to $95 \%$. 1995 deadline $2 / 10$.
Relevant Interests

Disseminating information re: protection and enhancement of natural resources.

Research, development \& demonstration projects re: causes, effects, extent, prevention, reduction, elimination of water pollution.

Support needed research into any aspect of water-resource-related problems deemed to be in the national interest.

For acquistion, restoration, enhancement, or management of coastal wetlands ecosystems.

Development of specialized model general permits for stormwater, pilot Municipal Pollution Prevention Programs.

Support implementation of US EPAapproved state nonpoint source management programs.

Support projects that restore \& manage sport fish populations, including pollution control techniques.

Projects that support development or enhancement of state wetland program.

Research, information transfer, and student training on one or more aspects of priority water problems.

Local clean-up and re-forestation projects. 


\begin{tabular}{|c|c|c|}
\hline Grant / Agency & Applicant Idigibility & Relevant Interests \\
\hline $\begin{array}{l}\text { Senior Enviroamental Employment } \\
\text { Program/ } \\
\text { US EPA Office of Research and } \\
\text { Development }\end{array}$ & $\begin{array}{l}\text { Private nonprofit organizations } \\
\text { eligible; local or state govts may be } \\
\text { beneficiaries. No matching funds } \\
\text { required. }\end{array}$ & $\begin{array}{l}\text { Projects for the prevention, } \\
\text { abatement, or control of pollution, } \\
\text { for which Americans } 55 \text { years or older } \\
\text { provide technical assistance. }\end{array}$ \\
\hline
\end{tabular}

Source: United States General Services Administration Office of Managment and Budget, 1994. 


\section{BIBLIOGRAPHY}

Adamowicz, Susan. 1995. Personal Communication. February 10.

Amdursky, Robert S. and Clayton P. Gillette. 1992. Municipal Debt Finance Law: Theory and Practice. Boston, MA: Little, Brown, and Company.

American Public Works Association. 1991. Public Works Management Practices. Washington, DC: APWA.

American Society of Civil Engineers and the Water Environment Federation. 1992. Design and Construction of Urban Stormwater Management Systems. New York, NY: ASCE.

APWA. See American Public Works Association.

Aronson, J. Richard and John L. Hilley. 1986. Financing State and Local Governments. Washington, DC: The Brookings Institution.

ASCE and WEF. See American Society of Civil Engineers and the Water Environment Federation.

Bartlett, Ronald E. 1981. Surface Water Sewerage, Second Edition. London: Applied Science Publishers, Ltd.

Beech, Gary. 1992. Lessons Learned: Milwaukee Water Pollution Abatement Program. Journal of Management in Engineering 8, 2 (April): 185-191.

Boyd, James. 1995. Personal Communication, February 6.

Brock, Thomas D. and Michael T. Madigan. 1991. Biology of Microorganisms, Sixth Edition. Englewood Cliffs, NJ: Prentice Hall.

Bureau of Census, United States Department of Commerce. 1993. Census of Population: General Population Characteristics, Part 41. Washington DC: Government Printing Office.

Buzzard's Bay Project. 1991. Buzzard's Bay Comprehensive Conservation Management Plan. Falmouth, Massachusetts: US EPA Region I/ Massachusetts Coastal Zone Management Office.

Buzzard's Bay Project. 1993. Final Report: The Effectiveness of a Stormwater Mitigation Project in Buttermilk Bay. Bourne, Massachusetts: Buzzard's Bay Project. 
Canter, Larry W. and Robert C. Knox. 1985. Septic Tank System Effects of Ground Water Quality. Chelsea, MA: Lewis Publishers.

City of East Providence. 1993. Excerpts from the Site Plan Review Procedures Manual and Other General Information Regarding the SPR/PUD Process in East Providence. East Providence, RI: City of East Providence.

City of Tallahassee. 1993. Environmental Management Ordinance. Tallahassee, Florida: City of Tallahassee.

City of Warwick. 1960. City Charter. Warwick, RI: City of Warwick.

. 1988. Subdivision Regulations. Warwick, RI: City of Warwick Planning Board.

1991. Comprehensive Plan. Warwick, RI: City of Warwick.

. 1994a. Special Capital Development Program of 1994. Warwick, RI: City of Warwick.

. 1994b. Strategic Plan for the Reclamation of Greenwich Bay. Warwick, RI: City of Warwick.

1994c. Capital Improvement Program and Budget: 1994 - 2000. Warwick, RI: City of Warwick.

. 1994d. City of Warwick Budget: Fiscal Year 1994-95. Warwick, RI: City of Warwick. 1994e. Zoning Ordinance. Warwick, RI: City of Warwick.

. 1994f. Greenwich Bay Progress Report. Warwick, RI: City of Warwick.

Clausen, John C. 1991. Evaluating Individual BMP's and Models. Pp. 143-144 in Eastern Research Group, ed.

Coffman, Lawrence. 1994. Best Management Practices for New Development: Pollutant Removal Efficiencies. Published in Cooperative Extension, ed.: Stormwater Management Workshop, November 17. Kingston, RI: University of Rhode Island.

Collins, Patrick S., Jean P. Marchand, and Dennis Daughters. Consolidating Stormwater Management: An Efficient Approach. Public Works 124, 7 (June): 52-53, 112.

Cowen, David J. 1988. GIS Versus CAD Versus DBMS: What Are the Differences? Photogrammetric Engineering and Remote Sensing 54, 11 (November): 1551-1555.

DePasquale, William. 1995. Personal Communication. January 31. 
Downing, Paul B. and Thomas J. Lorenzo. 1981. User Charges and Special Districts. Pp. 184-210 in J. Richard Aronson and Eli Schwartz, eds.: Management Policies in Local Government Finance. Washington, DC: International City Management Association.

Eastern Research Group, ed. 1991. Seminar Publication: Nonpoint Source Watershed Workshop. Washington, DC: US EPA.

Engemoen, Marc. 1985. Stormwater Management Emphasizes 'Soft Improvements'. Public Works 116, 7 (July): 66-67.

Engemoen, Marc and Roger E. Krempel. 1985. A Utility Approach to Comprehensive Stormwater Management. Public Works 116, 4 (April): 68-71, 92.

Engemoen, Marc, Michael Mercer, and Roger E. Krempel. 1985. Developing an Effective Storm Drainage Maintenance Program. Public Works 116, 6 (June): 84-89.

FDA. See Food and Drug Administration, United States Public Health Service.

Ferguson, Bruce K. 1994. Stormwater Infiltration. Boca Raton, FL: CRC Press.

Ferrari, Leilani. 1987. Surface Water Fees Used to Reduce Urban Flooding. Public Works 118, 8 (August): 66-67.

Field, R. 1991. Storm and Combined Sewer Overflows: An Overview of EPA's Research Program. Pp. 291-295 in C. Maksimovic: New Technologies in Urban Drainage, Urban Drainage and New Technologies 1991 Conference. London: Elsevier Applied Science.

Florida DEP. See Florida Department of Environmental Protection.

Florida Department of Environmental Protection. 1993. Model Local Government Stormwater Management Program. Tallahassee, FL: Florida DEP.

Food and Drug Administration, United States Public Health Service. 1994. Greenwich Bay, Rhode Island Shellfish Growing Area Survey and Classification Considerations. Davisville, RI: FDA.

Forester, John. 1989. Planning in the Face of Power. Berkeley, CA: University of California Press.

The Foundation Center. 1990. Corporate Foundation Profiles, Sixth Edition. New York, NY: The Foundation Center. 
Galli, John. 1992. Analysis of Urban BMP Performance and Longevity in Prince George's County, Maryland. Washington, DC: Metropolitan Washington Council of Governments.

Ganz, Arthur, Najih Lazar, and April Valliere. 1993. Quahaug Management Project, Phase I: Greenwich Bay. South Kingstown, RI: RIDEM Division of Fish, Wildlife and Estuarine Resources Coastal Fisheries Lab.

Gillette, Clayton P. 1994. Local Government Law. Boston, MA: Little, Brown, and Company.

Griffin, Carol B. 1993. Effectiveness of BMP's in Reducing Nitrogen to Long Island Sound. Syracuse, NY: SUNY College of Environmental Science and Forestry.

Guptill, Stephen C. 1989. Evaluating Geographic Information Systems Technology. Photogrammetric Engineering and Remote Sensing 55, 11 (November): 1583-1587.

Hansen, Nancy Richardson. 1991. The Stormwater Utility as a Local Regulatory Tool. Pp. 186-188 in Eastern Research Group, ed.

Hartigan, John P. 1988. Basis for Design of Wet Detention Basin BMP's. Pp. 122-143 in Roesner et al., eds.

Hawley, Mark E. and Richard H. McCuen. 1987. Elements of a Comprehensive Stormwater Management Program. Journal of Water Resources Planning and Management 113, 6 (November): 793-809.

Heaney, James P. 1986. Research Needs in Urban Stormwater Pollution. Journal of Water Resources Planning and Management 112, 1 (January): 36-47.

. 1988. Cost-Effectiveness and Urban Stormwater Quality Criteria. Pp. 84-98 in Roesner et al., eds.

Henry, J. Glynn and Gary W. Heinke. 1989. Environmental Science and Engineering. Englewood Cliffs, NJ: Prentice-Hall, Inc.

Holland, Daniel M. 1982. User Charges in the Wake of Tax and Expenditure Limitations. Pp. 1-11 in Lincoln Institute of Land Policy: The Impact of Fiscal Restraints: Alternative Financing by Localities, Lincoln Institute of Land Policy Monograph 82-7. Cambridge, MA: Lincoln Institute of Land Policy.

Hon, Katherine, ed. 1993. Water Management in the Nineties: A Time for Innovation, Proceedings of the 20th Anniversary Conference, ASCE Water Resources Planning and Management Division of the ASCE, Seattle, WA, May 1-5, 1993. New York: ASCE. 
Horsley and Witten, Inc. Coastal Protection Program: Workshops in Innovative Management Techniques for Estuaries, Wetlands, and Near Coastal Waters. Washington, DC: Office of Wetlands, Oceans and Watersheds, EPA.

Joubert, Lorraine. 1995. Personal Communication. April 18.

Kedzierski, John, Scott Acone, and Ulrika Volz. 1994. Runnins River Watershed Stormwater Management Study. Waltham, MA: United States Army Corps of Engineers New England Division.

Kienegger, Erwin H. 1992. Assessment of a Wastewater Service Charge by Integrating Aerial Photography and GIS. Photogrammetric Engineering and Remote Sensing 58, 11 (November): 1601-1606.

Lager, John A., William G. Smith, William G. Lynard, Robert M. Finn and E. John Finnemore. 1977. Urban Stormwater Management and Technology: Update and Users' Guide. Cinncinati, OH: US EPA Municipal Environmental Research Laboratory.

Lazaro, Timothy. 1979. Urban Hydrology: A Multi-disciplinary Perspective. Ann Arbor, MI: Ann Arbor Science Publishers.

Lindsey, Greg. 1988a. A Survey of Stormwater Utilities. Baltimore, MD: Maryland Department of the Environment, Stormwater Management Administration.

. 1988b. Financing Stormwater Management: The Utility Approach. Baltimore, MD: Maryland Department of the Environment, Stormwater Management Administration.

. 1990. Update to a Survey of Stormwater Utilities. Baltimore, MD: Maryland Department of the Environment, Stormwater Management Administration.

1991. Potential Revenues from Stormwater Utilities in Maryland. Baltimore, MD:

Maryland Department of the Environment, Stormwater Management Administration.

Livingston, Eric H. 1988. The Use of Wetlands for Urban Stormwater Management. Pp. 467-489 in Roesner, et al., eds.

Matzer, John Jr., editor. 1984 Practical Financial Management: New Techniques for Local Government. Washington, DC: International City Management Association.

Meisner, Laurence J. and Laura Firtel. 1988. Private Funding for Roads, Planning Advisory Service Report No. 426. Chicago, IL: American Planning Association. 
Meyer, Steffen P., Tarek H. Salem, and John W. Labadie. 1993. Geographic Information Systems in Urban Stormwater Management. Journal of Water Resources Planning and Management 119, 2 (March/ April): 206-228.

Millar, Scott. 1994. Personal Communication. December 5.

Montgomery Watson. 1994. Defining the Urban Stormwater Runoff Problem, A Report Prepared for the National League of Cities and the National Realty Committee. Walnut Creek, California: Montgomery Watson.

Morgan, David R. 1984. Managing Urban America. Washington, DC: International City Managers Association.

Morrison, Tim, Malcolm Alter, and Robert H. Wassum. 1994. Comprehensive Stormwater Management Study. Public Works 125, 2 (February): 40-41.

Narragansett Bay Project, Rhode Island Department of Environmental Management. 1994. Greenwich Bay Watershed Restoration Initiative, Fact Sheet (March). Providence Rhode Island: NBP.

National Network of Grantmakers. 1989. Grant Seekers Guide, Third Edition. Mount Kisco, NY: Meyer-Bell Ltd.

National Oceanic and Atmospheric Administration and US EPA. 1993. Coastal Nonpoint Pollution Control Program. Washington, DC: NOAA and US EPA.

NBP. See Narragansett Bay Project.

Nicholas, James. C. 1989. The Calculation of Proportionate-Share Impact Fees. Planning Advisory Service Report No. 408. Chicago, IL: American Planning Association.

NOAA. See National Oceanic and Atmospheric Administration.

Northern Virginia Soil and Water Conservation District. 1994. Control Programs for Urbanized Areas. Richmond, VA: NVSWCD.

NVSWCD. See Northern Virginia Soil and Water Conservation District.

Offenberg, Eric. 1995. Personal Communication. April 10.

Office of Management and Budget, United States General Services Administration. 1994. Catalogue of Federal Domestic Assistance. Washington, DC: Government Printing Office. 
OMB. See Office of Management and Budget, United States General Services Administration.

Patton, Carl V. and David S. Sawicki. 1993. Basic Methods of Policy Analysis and Planning, Second Edition. Englewood Cliffs, NJ: Prentice Hall.

Pazwash, Hormoz. 1993. Stormwater Management Practices in New Jersey: Suggestions for Improvements. Pp. 1188-1193 in Chin Y. Kuo, ed.: Engineering Hydrology: Proceedings of the ASCE Hydraulics Division Symposium in San Francisco, CA, July 25-30, 1993. New York: ASCE.

Perrich, Jerry R. 1993. Implementing Stormwater Plans. Pollution Engineering 25, 10 (May 15): 24-26.

Peterson, George E., Rita Bamberger, Nancy Humphrey, and Kenneth M. Steil. 1984. Guide to Financing the Capital Budget and Maintenance Plan, Volume 6 of Guides to Managing Urban Capital Series. Washington, DC: The Urban Institute Press.

Poertner, Herbert G. 1981. Better Ways to Manage Stormwater Management. Civil Engineering-ASCE 51,4 (April): 67, 68-69.

Prince George's County. 1986. Report to the County Executive: Feasibility Study on the Transfer of the WSSC's Storm Drainage Functions to the Prince George's County Government. Upper Marlboro, MD: Prince George's County Government.

Pyzoha, David S. 1994. Implementing a Stormwater Management Program. Boca Raton, FL: CRC Press, Inc.

Quade, Edward S. 1989. Analysis for Public Decisions, Third Edition. Englewood Cliffs, NJ: Prentice-Hall, Inc.

Rhode Island Coastal Resources Management Council. 1990. The State of Rhode Island Coastal Resources Management Program. Kingston, RI: URI Publications Office.

.1993. Addendum to the State of Rhode Island Coastal Resources Management Program: Treatment of Sewage and Stormwater. Wakefield, RI: RI CRMC.

. 1994. Rhode Island Undergoes Threshold Review of Proposed Coastal Nonpoint Pollution Control Program. Coastal Features III, 1 (Fall): 1, 6.

Rhode Island. 1956 (1994 Cumulative Update). Rhode Island General Laws. Charlottesville, VA: The Michie Co. 
Rhode Island Department of Environmental Management. 1988a. State of the State's Waters. Providence, RI: RIDEM.

. 1988b. Water Quality Regulations for Water Pollution Control. Providence, RI: RIDEM.

. 1990. State of the State's Waters. Providence, RI: RIDEM.

. 1992. State of the State's Waters. Providence, RI: RIDEM.

. 1994a. Rules and Regulations Governing the Administration and Enforcement of the Freshwater Wetlands Act. Providence, RI: RIDEM.

. 1994b. State of the State's Waters. Providence, RI: RIDEM.

and RI CRMC. 1993. State of Rhode Island Stormwater Design and Installation Standards Manual. Providence, RI: RIDEM.

Rhode Island Geographic Information System, Division of Planning, Rhode Island Department of Administration. 1988. Data for the Greenwich Bay Watershed. Providence, RI: RIGIS.

RI CRMC. See Rhode Island Coastal Resources Management Council.

RIDEM. See Rhode Island Department of Environmental Management.

RIGIS. See Rhode Island Geographic Information System.

Robbins, Clarence H. 1994. Stormwater Funding. Environmental Protection (May): 32-34, 36.

Roesner, Larry A., Ben Urbonas and Michael B. Sonnen. 1988. Design of Urban Runoff Quality Controls, Proceedings of an Engineering Foundation Conference on Current Practices and Design Criteria for Urban Quality Control. New York: ASCE.

Scharlach, Anne: Project Manager, City of Austin Department of Environment and Conservation, Stormwater Retrofit Program. 1995. Personal Communication. February 24.

Schmidt, Stacy D. and Douglas R. Spencer. 1986. The Magnitude of Improper Waste Discharges in an Urban Stormwater System. Joumal of the Water Pollution Control Federation 58, 7 (July): 744-747. 
Schueler, Thomas R. 1987. Controlling Urban Runoff: A Practical Manual for Planning and Designing Urban BMP's. Washington, DC: Metropolitan Washington Council of Governments.

1991. Mitigating the Adverse Impacts of Urbanization on Streams: A Comprehensive Strategy for Local Government. Pp. 114-123 in Eastern Research Group, ed.

. 1994a. The Emerging Field of Watershed Protection. Watershed Protection Techniques 1, 1 (February): 1.

. 1994b. Developments in Sand Filter Technology to Improve Stormwater Runoff Quality. Watershed Protection Techniques 1, 2 (Summer): 47-54.

, John Galli, Lorrie Herson, Peter Kumble, and David Shepp. 1991. Developing Effective BMP Systems for Urban Watersheds. Pp. 69-84 in Eastern Research Group, ed.

, Peter A. Kumble, and Maureen A. Heraty. 1992. A Current Assessment of Urban Best Management Practices: Techniques for Reducing Non-Point Source Pollution in the Coastal Zone. Washington, DC: Metropolitan Washington Council of Governments.

SCS. See Soil Conservation Service, United States Department of Agriculture.

Sear, Thomas R. and Ronald L. Wycoff. 1993. Selection of Optimal Best Management Practices (BMP's). Pp. 747-750 in Hon, ed.

Shaver, H. Earl. 1988. Institutional Stormwater Management Issues. Pp. 340-348 in Roesner, et al.

Shea, Conor, Walter Grayman, Douglas Darden, Richard Males, and Peter Sushinsky. 1993. Integrated GIS and Hydrologic Modeling for Countywide Drainage Study. Journal of Water Resources Planning and Management 119, 2 (March/ April): 112-128.

Sheahan, Charles T. 1995. Personal Communication. February 8.

Soil Conservation Service, United States Department of Agriculture. 1961. Soils Suitable for Septic Tank Filter Fields, Agriculture Information Bulletin No. 243. Washington, DC: U.S. Government Printing Office.

Spinnard, Theodore. 1995. Personal Communication. April 10.

Stanier, Roger Y., John L. Ingraham, Mark L. Wheelis, and Page R. Painter. 1986. The Microbial World, Fifth Edition. Englewood Cliffs, NJ: Prentice Hall. 
Stephenson, D. 1981. Stormwater Hydrology and Drainage. Amsterdam, The Netherlands: Elsevier Scientific Publishing Company.

Stevens, Jonathan. 1994. Personal Communication. June 13.

Stitt, Thomas A. 1986. Establishing a Stormwater Management Utility. Public Works 117, 9 (September): 126-127, 150-156.

Terrene Institute. 1994. Urbanization and Water Quality. Washington, DC: Terrene Institute.

Tucker, L. Scott. 1976. Urban Drainage and Flood Control Programs. Pp. 401-424 in William Korbitz, ed.: Urban Public Works Administration. Washington, DC: International City Managers Association.

United States Environmental Protection Agency. Nationwide Urban Runoff Program: Final Report. Washington, DC: US EPA.

. 1992. Financing Marine and Estuarine Programs: A Guide to Resources. Washington, DC: US EPA.

. 1993a. Guidance Specifying Management Measures for Sources of Nonpoint Pollution in Coastal Waters. Washington, DC: US EPA Office of Water.

. 1993b. Investigation of Inappropriate Pollutant Entries into Storm Drainage Systems: A User's Guide. Washington, DC: US EPA Office of Research and Development.

. 1993c. Handbook: Urban Runoff. Washington, DC: US EPA.

USDA. See United States Department of Agriculture.

US EPA. See United States Environmental Protection Agency.

Villella, William. 1995a. Personal Communication. February 8.

Villella, William. 1995b. Personal Communication. February 22.

Wanielista, Martin P. 1979. Stormwater Management: Quantity and Quality. Ann Arbor, MI: Ann Arbor Science Publishers Inc.

Washington County, Oregon, Stormwater Program. No Date. Planned Crew Configurations and Performance Standards. Published in University of Rhode Island Cooperative Extension, ed.: Stormwater Management Workshop, November 17. Kingston, RI: University of Rhode Island. 
Whipple, William, Jr. 1991. Best Management Practices for Stormwater and Infiltration Control. Water Resources Bulletin 27, 6 (December): 895-901. . Neil S. Grigg, Thomas Grizzard, Clifford W. Randall, Robert P. Shubinski, and L. Scott Tucker. 1983. Stormwater Management in Urbanizing Areas. Englewood Cliffs NJ: Prentice-Hall, Inc.

Wilson, J.D. 1993. GIS Meets Return on Investment. Public Works 124, 6 (May): 39-41.

Woodcock, Curtis E., Chi Ho Sham, and Barbara Shaw. 1990. Comments on Selecting a Geographic Information System for Environmental Management. Environmental Management 14, 3: 307-315.

Yard, Mary Julianne. 1991. Establishing a Stormwater Utility: Considerations for the Local Government Lawyer. Florida Bar Journal 64 (December): 36-38. 


\section{BIBLIOGRAPHY}

Adamowicz, Susan. NBP. 1995. Telephone Communication. February 10.

Amdursky, Robert S. and Clayton P. Gillette. 1992. Municipal Debt Finance Law: Theory and Practice. Boston, MA: Little, Brown, and Company.

American Public Works Association. 1991. Public Works Management Practices. Washington, DC: APWA.

American Society of Civil Engineers and the Water Environment Federation. 1992. Design and Construction of Urban Stormwater Management Systems. New York, NY: ASCE.

APWA. See American Public Works Association.

Aronson, J. Richard and John L. Hilley. 1986. Financing State and Local Governments. Washington, DC: The Brookings Institution.

ASCE and WEF. See American Society of Civil Engineers and the Water Environment Federation.

Bartlett, Ronald E. 1981. Surface Water Sewerage, Second Edition. London: Applied Science Publishers, Ltd.

Beech, Gary. 1992. Lessons Learned: Milwaukee Water Pollution Abatement Program. Journal of Management in Engineering 8, 2 (April): 185-191.

Boyd, James. RI CRMC. 1995. Telephone Communication, February 6.

Brock, Thomas D. and Michael T. Madigan. 1991. Biology of Microorganisms, Sixth Edition. Englewood Cliffs, NJ: Prentice Hall.

Bureau of Census, United States Department of Commerce. 1993. Census of Population: General Population Characteristics, Part 41. Washington DC: Government Printing Office.

Buzzard's Bay Project. 1991. Buzzard's Bay Comprehensive Conservation Management Plan. Falmouth, Massachusetts: US EPA Region I/ Massachusetts Coastal Zone Management Office.

Buzzard's Bay Project. 1993. Final Report: The Effectiveness of a Stormwater Mitigation Project in Buttermilk Bay. Bourne, Massachusetts: Buzzard's Bay Project. 
Canter, Larry W. and Robert C. Knox. 1985. Septic Tank System Effects of Ground Water Quality. Chelsea, MA: Lewis Publishers.

City of East Providence. 1993. Excerpts from the Site Plan Review Procedures Manual and Other General Information Regarding the SPR/PUD Process in East Providence. East Providence, RI: City of East Providence.

City of Tallahassee. 1993. Environmental Management Ordinance. Tallahassee, Florida: City of Tallahassee.

City of Warwick. 1960. City Charter. Warwick, RI: City of Warwick.

1988. Subdivision Regulations. Warwick, RI: City of Warwick Planning Board.

. 1991. Comprehensive Plan. Warwick, RI: City of Warwick.

. 1994a. Special Capital Development Program of 1994. Warwick, RI: City of Warwick.

. 1994b. Strategic Plan for the Reclamation of Greenwich Bay. Warwick, RI: City of Warwick.

. 1994c. Capital Improvement Program and Budget: 1994 - 2000. Warwick, RI: City of Warwick.

. 1994d. City of Warwick Budget: Fiscal Year 1994-95. Warwick, RI: City of Warwick.

. 1994e. Zoning Ordinance. Warwick, RI: City of Warwick.

. 1994f. Greenwich Bay Progress Report. Warwick, RI: City of Warwick.

Clausen, John C. 1991. Evaluating Individual BMP's and Models. Pp. 143-144 in Eastern Research Group, ed.

Coffman, Lawrence. 1994. Best Management Practices for New Development: Pollutant Removal Efficiencies. Published in Cooperative Extension, ed.: Stormwater Management Workshop, November 17. Kingston, RI: University of Rhode Island.

Collins, Patrick S., Jean P. Marchand, and Dennis Daughters. Consolidating Stormwater Management: An Efficient Approach. Public Works 124, 7 (June): 52-53, 112.

Cowen, David J. 1988. GIS Versus CAD Versus DBMS: What Are the Differences? Photogrammetric Engineering and Remote Sensing 54, 11 (November): 1551-1555. 
DePasquale, William. City of Warwick Department of Planning. 1995. Personal Communication. January 31.

Downing, Paul B. and Thomas J. Lorenzo. 1981. User Charges and Special Districts. Pp. 184-210 in J. Richard Aronson and Eli Schwartz, eds.: Management Policies in Local Government Finance. Washington, DC: International City Management Association.

Eastern Research Group, ed. 1991. Seminar Publication: Nonpoint Source Watershed Workshop. Washington, DC: US EPA.

Engemoen, Marc. 1985. Stormwater Management Emphasizes 'Soft Improvements'. Public Works 116, 7 (July): 66-67.

Engemoen, Marc and Roger E. Krempel. 1985. A Utility Approach to Comprehensive Stormwater Management. Public Works 116, 4 (April): 68-71, 92.

Engemoen, Marc, Michael Mercer, and Roger E. Krempel. 1985. Developing an Effective Storm Drainage Maintenance Program. Public Works 116, 6 (June): 84-89.

FDA. See Food and Drug Administration, United States Public Health Service.

Ferguson, Bruce K. 1994. Stormwater Infiltration. Boca Raton, FL: CRC Press.

Ferrari, Leilani. 1987. Surface Water Fees Used to Reduce Urban Flooding. Public Works 118, 8 (August): 66-67.

Field, R. 1991. Storm and Combined Sewer Overflows: An Overview of EPA's Research Program. Pp. 291-295 in C. Maksimovic: New Technologies in Urban Drainage, Urban Drainage and New Technologies 1991 Conference. London: Elsevier Applied Science.

Florida DEP. See Florida Department of Environmental Protection.

Florida Department of Environmental Protection. 1993. Model Local Government Stormwater Management Program. Tallahassee, FL: Florida DEP.

Food and Drug Administration, United States Public Health Service. 1994. Greenwich Bay, Rhode Island Shellfish Growing Area Survey and Classification Considerations. Davisville, RI: FDA.

Forester, John. 1989. Planning in the Face of Power. Berkeley, CA: University of California Press. 
The Foundation Center. 1990. Corporate Foundation Profiles, Sixth Edition. New York, NY: The Foundation Center.

Galli, John. 1992. Analysis of Urban BMP Performance and Longevity in Prince George's County, Maryland. Washington, DC: Metropolitan Washington Council of Governments.

Ganz, Arthur, Najih Lazar, and April Valliere. 1993. Quahaug Management Project, Phase I: Greenwich Bay. South Kingstown, RI: RIDEM Division of Fish, Wildlife and Estuarine Resources Coastal Fisheries Lab.

Gillette, Clayton P. 1994. Local Government Law. Boston, MA: Little, Brown, and Company.

Griffin, Carol B. 1993. Effectiveness of BMP's in Reducing Nitrogen to Long Island Sound. Syracuse, NY: SUNY College of Environmental Science and Forestry.

Guptill, Stephen C. 1989. Evaluating Geographic Information Systems Technology. Photogrammetric Engineering and Remote Sensing 55, 11 (November): 1583-1587.

Hansen, Nancy Richardson. 1991. The Stormwater Utility as a Local Regulatory Tool. Pp. 186-188 in Eastern Research Group, ed.

Hartigan, John P. 1988. Basis for Design of Wet Detention Basin BMP's. Pp. 122-143 in Roesner et al., eds.

Hawley, Mark E. and Richard H. McCuen. 1987. Elements of a Comprehensive Stormwater Management Program. Journal of Water Resources Planning and Management 113, 6 (November): 793-809.

Heaney, James P. 1986. Research Needs in Urban Stormwater Pollution. Journal of Water Resources Planning and Management 112, 1 (January): 36-47.

. 1988. Cost-Effectiveness and Urban Stormwater Quality Criteria. Pp. 84-98 in Roesner et al., eds.

Henry, J. Glynn and Gary W. Heinke. 1989. Environmental Science and Engineering. Englewood Cliffs, NJ: Prentice-Hall, Inc.

Holland, Daniel M. 1982. User Charges in the Wake of Tax and Expenditure Limitations. Pp. 1-11 in Lincoln Institute of Land Policy: The Impact of Fiscal Restraints: Alternative Financing by Localities, Lincoln Institute of Land Policy Monograph 82-7. Cambridge, MA: Lincoln Institute of Land Policy. 
Hon, Katherine, ed. 1993. Water Management in the Nineties: A Time for Innovation, Proceedings of the 20th Anniversary Conference, ASCE Water Resources Planning and Management Division of the ASCE, Seattle, WA, May 1-5, 1993. New York: ASCE.

Horsley and Witten, Inc. Coastal Protection Program: Workshops in Innovative Management Techniques for Estuaries, Wetlands, and Near Coastal Waters. Washington, DC: Office of Wetlands, Oceans and Watersheds, EPA.

Joubert, Lorraine. University of Rhode Island Cooperative Extension. 1995. Personal Communication. April 18.

Kedzierski, John, Scott Acone, and Ulrika Volz. 1994. Runnins River Watershed Stormwater Management Study. Waltham, MA: United States Army Corps of Engineers New England Division.

Kienegger, Erwin H. 1992. Assessment of a Wastewater Service Charge by Integrating Aerial Photography and GIS. Photogrammetric Engineering and Remote Sensing 58, 11 (November): 1601-1606.

Lager, John A., William G. Smith, William G. Lynard, Robert M. Finn and E. John Finnemore. 1977. Urban Stormwater Management and Technology: Update and Users' Guide. Cinncinati, OH: US EPA Municipal Environmental Research Laboratory.

Lazaro, Timothy. 1979. Urban Hydrology: A Multi-disciplinary Perspective. Ann Arbor, MI: Ann Arbor Science Publishers.

Lindsey, Greg. 1988a. A Survey of Stormwater Utilities. Baltimore, MD: Maryland Department of the Environment, Stormwater Management Administration.

. 1988b. Financing Stormwater Management: The Utility Approach. Baltimore, MD: Maryland Department of the Environment, Stormwater Management Administration.

. 1990. Update to a Survey of Stormwater Utilities. Baltimore, MD: Maryland Department of the Environment, Stormwater Management Administration.

1991. Potential Revenues from Stormwater Utilities in Maryland. Baltimore, MD: Maryland Department of the Environment, Stormwater Management Administration.

Livingston, Eric H. 1988. The Use of Wetlands for Urban Stormwater Management. Pp. 467-489 in Roesner, et al., eds.

Matzer, John Jr., editor. 1984 Practical Financial Management: New Techniques for Local Government. Washington, DC: International City Management Association. 
Meisner, Laurence J. and Laura Firtel. 1988. Private Funding for Roads, Planning Advisory Service Report No. 426. Chicago, IL: American Planning Association.

Meyer, Steffen P., Tarek H. Salem, and John W. Labadie. 1993. Geographic Information Systems in Urban Stormwater Management. Journal of Water Resources Planning and Management 119, 2 (March/ April): 206-228.

Millar, Scott. RIDEM Office of Environmental Coordination. 1994. Telephone Communication. December 5.

Montgomery Watson. 1994. Defining the Urban Stormwater Runoff Problem, A Report Prepared for the National League of Cities and the National Realty Committee. Walnut Creek, California: Montgomery Watson.

Morgan, David R. 1984. Managing Urban America. Washington, DC: International City Managers Association.

Morrison, Tim, Malcolm Alter, and Robert H. Wassum. 1994. Comprehensive Stormwater Management Study. Public Works 125, 2 (February): 40-41.

Narragansett Bay Project, Rhode Island Department of Environmental Management. 1994. Greenwich Bay Watershed Restoration Initiative, Fact Sheet (March). Providence Rhode Island: NBP.

National Network of Grantmakers. 1989. Grant Seekers Guide, Third Edition. Mount Kisco, NY: Meyer-Bell Ltd.

National Oceanic and Atmospheric Administration and US EPA. 1993. Coastal Nonpoint Pollution Control Program. Washington, DC: NOAA and US EPA.

NBP. See Narragansett Bay Project.

NCRS. See Soil Conservation Service.

Nicholas, James. C. 1989. The Calculation of Proportionate-Share Impact Fees. Planning Advisory Service Report No. 408. Chicago, IL: American Planning Association.

NOAA. See National Oceanic and Atmospheric Administration.

Northern Virginia Soil and Water Conservation District. 1994. Control Programs for Urbanized Areas. Richmond, VA: NVSWCD.

NVSWCD. See Northern Virginia Soil and Water Conservation District. 
Offenberg, Eric. Southern Rhode Island Conservation District. 1995. Personal Communication. April 10.

Office of Management and Budget, United States General Services Administration. 1994. Catalogue of Federal Domestic Assistance. Washington, DC: Government Printing Office.

OMB. See Office of Management and Budget, United States General Services Administration.

Patton, Carl V. and David S. Sawicki. 1993. Basic Methods of Policy Analysis and Planning, Second Edition. Englewood Cliffs, NJ: Prentice Hall.

Pazwash, Hormoz. 1993. Stormwater Management Practices in New Jersey: Suggestions for Improvements. Pp. 1188-1193 in Chin Y. Kuo, ed.: Engineering Hydrology: Proceedings of the ASCE Hydraulics Division Symposium in San Francisco, CA, July 25-30, 1993. New York: ASCE.

Perrich, Jerry R. 1993. Implementing Stormwater Plans. Pollution Engineering 25, 10 (May 15): 24-26.

Peterson, George E., Rita Bamberger, Nancy Humphrey, and Kenneth M. Steil. 1984. Guide to Financing the Capital Budget and Maintenance Plan, Volume 6 of Guides to Managing Urban Capital Series. Washington, DC: The Urban Institute Press.

Poertner, Herbert G. 1981. Better Ways to Manage Stormwater Management. Civil Engineering-ASCE 51,4 (April): 67, 68-69.

Prince George's County. 1986. Report to the County Executive: Feasibility Study on the Transfer of the WSSC's Storm Drainage Functions to the Prince George's County Government. Upper Marlboro, MD: Prince George's County Government.

Pyzoha, David S. 1994. Implementing a Stormwater Management Program. Boca Raton, FL: CRC Press, Inc.

Quade, Edward S. 1989. Analysis for Public Decisions, Third Edition. Englewood Cliffs, NJ: Prentice-Hall, Inc.

Rhode Island Coastal Resources Management Council. 1990. The State of Rhode Island Coastal Resources Management Program. Kingston, RI: URI Publications Office. 1993. Addendum to the State of Rhode Island Coastal Resources Management Program: Treatment of Sewage and Stormwater. Wakefield, RI: RI CRMC. 
. 1994. Rhode Island Undergoes Threshold Review of Proposed Coastal Nonpoint Pollution Control Program. Coastal Features III, 1 (Fall): 1, 6.

Rhode Island. 1956 (1994 Cumulative Update). Rhode Island General Laws. Charlottesville, VA: The Michie Co.

Rhode Island Department of Environmental Management. 1988a. State of the State's Waters. Providence, RI: RIDEM.

. 1988b. Water Quality Regulations for Water Pollution Control. Providence, RI: RIDEM.

. 1990. State of the State's Waters. Providence, RI: RIDEM.

. 1992. State of the State's Waters. Providence, RI: RIDEM.

- 1994a. Rules and Regulations Governing the Administration and Enforcement of the Freshwater Wetlands Act. Providence, RI: RIDEM.

. 1994b. State of the State's Waters. Providence, RI: RIDEM.

and RI CRMC. 1993. State of Rhode Island Stormwater Design and Installation Standards Manual. Providence, RI: RIDEM.

Rhode Island Geographic Information System, Division of Planning, Rhode Island Department of Administration. 1988. Data for the Greenwich Bay Watershed. Providence, RI: RIGIS.

RI CRMC. See Rhode Island Coastal Resources Management Council.

RIDEM. See Rhode Island Department of Environmental Management.

RIGIS. See Rhode Island Geographic Information System.

Robbins, Clarence H. 1994. Stormwater Funding. Environmental Protection (May): 32-34, 36.

Roesner, Larry A., Ben Urbonas and Michael B. Sonnen. 1988. Design of Urban Runoff Quality Controls, Proceedings of an Engineering Foundation Conference on Current Practices and Design Criteria for Urban Quality Control. New York: ASCE.

Scharlach, Anne. Project Manager, City of Austin Department of Environment and Conservation, Stormwater Retrofit Program. 1995. Telephone Communication. February 24. 
Schmidt, Stacy D. and Douglas R. Spencer. 1986. The Magnitude of Improper Waste Discharges in an Urban Stormwater System. Journal of the Water Pollution Control Federation 58, 7 (July): 744-747.

Schueler, Thomas R. 1987. Controlling Urban Runoff: A Practical Manual for Planning and Designing Urban BMP's. Washington, DC: Metropolitan Washington Council of Governments.

. 1991. Mitigating the Adverse Impacts of Urbanization on Streams: A Comprehensive Strategy for Local Government. Pp. 114-123 in Eastern Research Group, ed.

. 1994a. The Emerging Field of Watershed Protection. Watershed Protection Techniques 1, 1 (February): 1.

. 1994b. Developments in Sand Filter Technology to Improve Stormwater Runoff Quality. Watershed Protection Techniques 1, 2 (Summer): 47-54.

, John Galli, Lorrie Herson, Peter Kumble, and David Shepp. 1991. Developing Effective BMP Systems for Urban Watersheds. Pp. 69-84 in Eastern Research Group, ed.

, Peter A. Kumble, and Maureen A. Heraty. 1992. A Current Assessment of Urban Best Management Practices: Techniques for Reducing Non-Point Source Pollution in the Coastal Zone. Washington, DC: Metropolitan Washington Council of Governments.

SCS. See Soil Conservation Service, United States Department of Agriculture.

Sear, Thomas R. and Ronald L. Wycoff. 1993. Selection of Optimal Best Management Practices (BMP's). Pp. 747-750 in Hon, ed.

Shaver, H. Earl. 1988. Institutional Stormwater Management Issues. Pp. 340-348 in Roesner, et al.

Shea, Conor, Walter Grayman, Douglas Darden, Richard Males, and Peter Sushinsky. 1993. Integrated GIS and Hydrologic Modeling for Countywide Drainage Study. Journal of Water Resources Planning and Management 119, 2 (March/ April): 112-128.

Sheahan, Charles T. Director, City of Warwick Department of Public Works. 1995. Personal Communication. February 8.

Soil Conservation Service (renamed the Natural Resources Conservation Service), United States Department of Agriculture. 1961. Soils Suitable for Septic Tank Filter Fields, Agriculture Information Bulletin No. 243. Washington, DC: U.S. Government Printing Office. 
Spinnard, Theodore. Maguire Group, Providence, Rhode Island. 1995. Personal Communication. April 10.

Stanier, Roger Y., John L. Ingraham, Mark L. Wheelis, and Page R. Painter. 1986. The Microbial World, Fifth Edition. Englewood Cliffs, NJ: Prentice Hall.

Stephenson, D. 1981. Stormwater Hydrology and Drainage. Amsterdam, The Netherlands: Elsevier Scientific Publishing Company.

Stevens, Jonathan. Director, City of Warwick Department of Planning. 1994. Personal Communication. June 13.

Stitt, Thomas A. 1986. Establishing a Stormwater Management Utility. Public Works 117, 9 (September): 126-127, 150-156.

Terrene Institute. 1994. Urbanization and Water Quality. Washington, DC: Terrene Institute.

Tucker, L. Scott. 1976. Urban Drainage and Flood Control Programs. Pp. 401-424 in William Korbitz, ed.: Urban Public Works Administration. Washington, DC: International City Managers Association.

United States Environmental Protection Agency. Nationwide Urban Runoff Program: Final Report. Washington, DC: US EPA.

1992. Financing Marine and Estuarine Programs: A Guide to Resources. Washington, DC: US EPA.

. 1993a. Guidance Specifying Management Measures for Sources of Nonpoint Pollution in Coastal Waters. Washington, DC: US EPA Office of Water.

. 1993b. Investigation of Inappropriate Pollutant Entries into Storm Drainage Systems: A User's Guide. Washington, DC: US EPA Office of Research and Development.

. 1993c. Handbook: Urban Runoff. Washington, DC: US EPA.

USDA. See United States Department of Agriculture.

US EPA. See United States Environmental Protection Agency.

Villella, William. Assistant City Engineer, City of Warwick Department of Public Works. 1995a. Personal Communication. February 8.

Villella, William. 1995b. Personal Communication. February 22. 
Wanielista, Martin P. 1979. Stormwater Management: Quantity and Quality. Ann Arbor, MI: Ann Arbor Science Publishers Inc.

Washington County, Oregon, Stormwater Program. No Date. Planned Crew Configurations and Performance Standards. Published in University of Rhode Island Cooperative Extension, ed.: Stormwater Management Workshop, November 17. Kingston, RI: University of Rhode Island.

Whipple, William, Jr. 1991. Best Management Practices for Stormwater and Infiltration Control. Water Resources Bulletin 27, 6 (December): 895-901.

. Neil S. Grigg, Thomas Grizzard, Clifford W. Randall, Robert P. Shubinski, and L. Scott Tucker. 1983. Stormwater Management in Urbanizing Areas. Englewood Cliffs NJ: Prentice-Hall, Inc.

Wilson, J.D. 1993. GIS Meets Return on Investment. Public Works 124, 6 (May): 39-41.

Woodcock, Curtis E., Chi Ho Sham, and Barbara Shaw. 1990. Comments on Selecting a Geographic Information System for Environmental Management. Environmental Management 14, 3: 307-315.

Yard, Mary Julianne. 1991. Establishing a Stormwater Utility: Considerations for the Local Government Lawyer. Florida Bar Journal 64 (December): 36-38. 